\title{
MITOPOÉTICAS DO CORPO
}

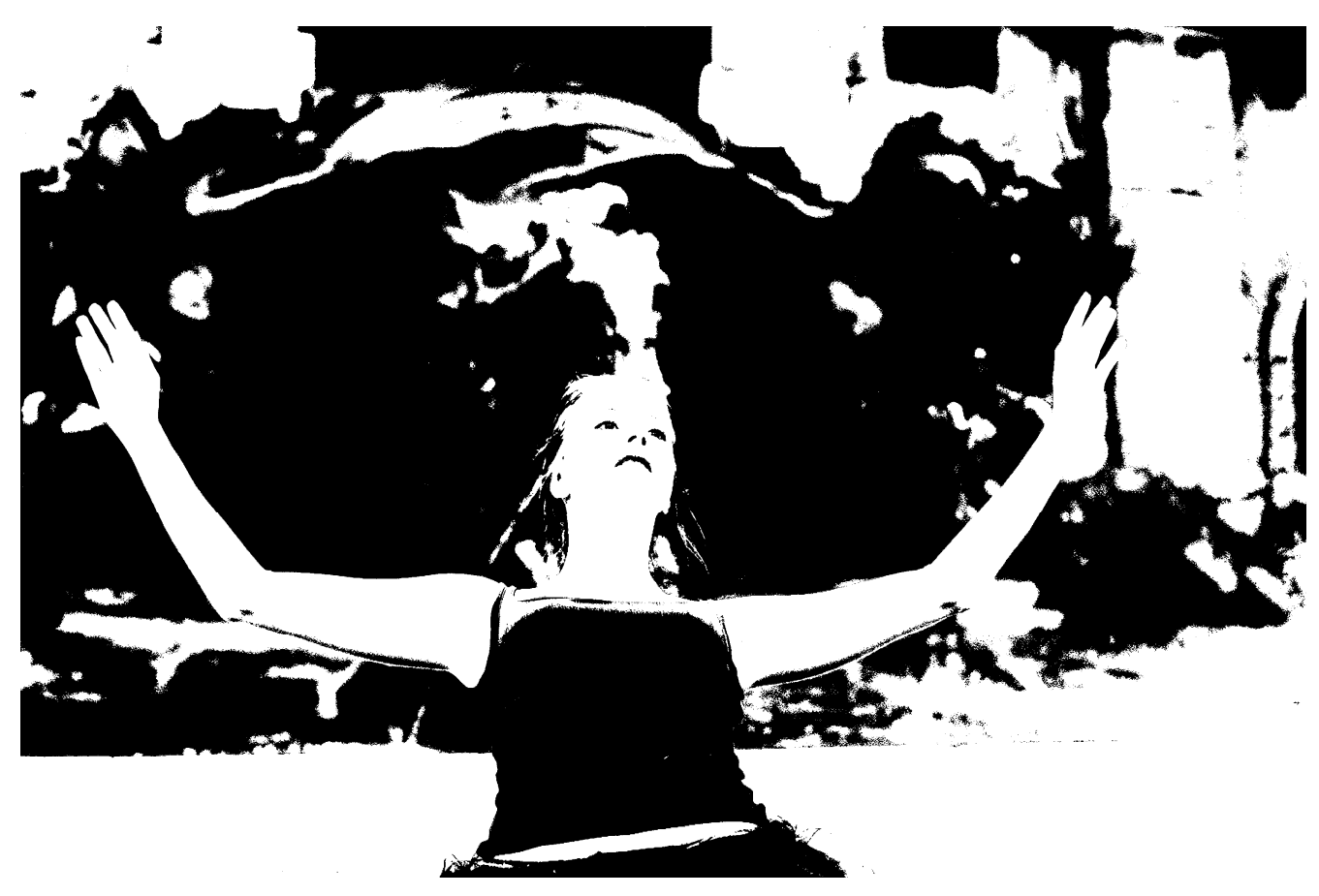

FLÁVIA COUTO

Dissertação de Mestrado - Artes Cênicas. Escola de Comunicação e Artes da Universidade de São Paulo, 2008. 


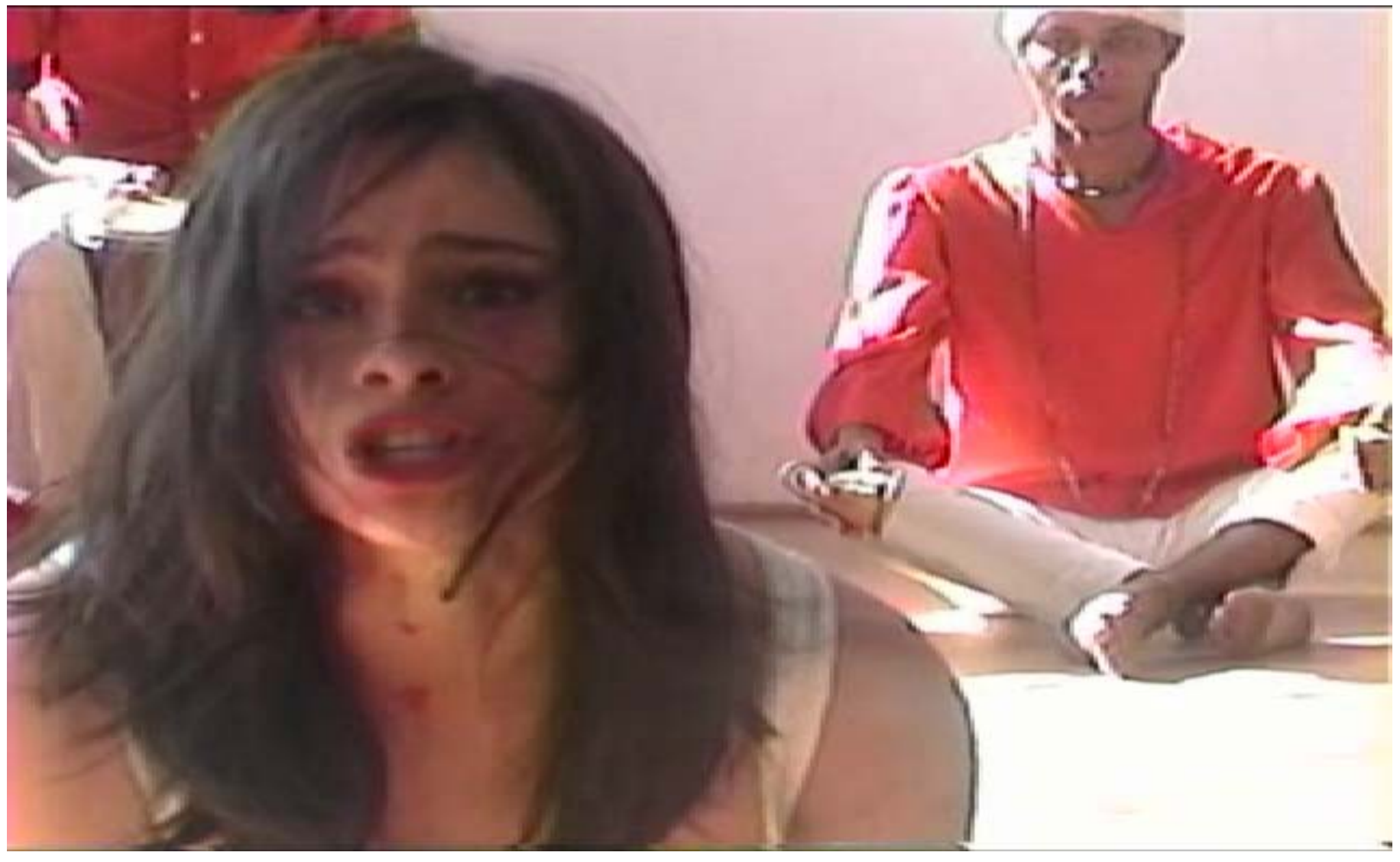




\section{MITOPOÉTICAS DO CORPO}

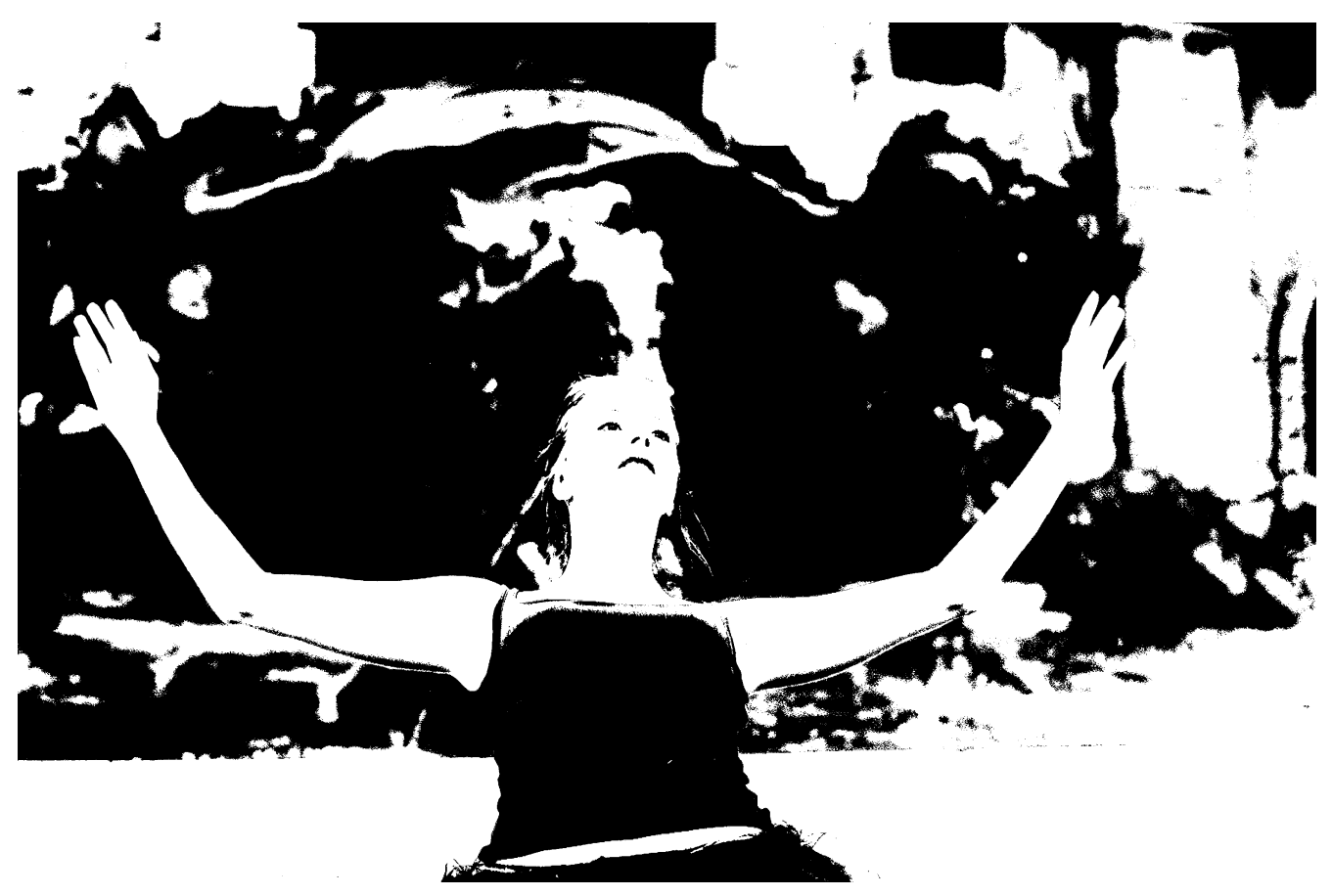

FLÁVIA COUTO

Dissertação de Mestrado - Artes Cênicas. Escola de Comunicação e Artes da Universidade de São Paulo, 2008. 


\title{
Universidade de São Paulo \\ Escola de Comunicações e Artes - ECA/USP
}

\author{
FLÁVIA COUTO
}

\section{MITOPOÉTICAS DO CORPO}

Dissertação apresentada à Escola de

Comunicações e Artes da Universidade de São

Paulo para obtenção do título de Mestre. Área

de concentração: Artes Cênicas. Orientação:

Prof. Dr. Armando Sérgio da Silva.

São Paulo, 2008 
Universidade de São Paulo

Escola de Comunicações e Artes - ECA/USP

FLÁVIA COUTO

\section{MITOPOÉTICAS DO CORPO}

Banca Examinadora 


\section{Agradecimentos}

\section{Aos meus familiares:}

À minha mãe por todo apoio que me deu em todos os passos de minha trajetória de atriz, por todo estímulo e suporte que me ofereceu em todas as minhas crises. Por ter me ensinado a querer sempre ir além dos limites e me amparado nos momentos de fraqueza e indecisão.

À meu pai por todo apoio e estímulo nos momentos mais importante de minha trajetória.

À minha irmã pelos conselhos e paciência com os quais acompanhou muitos momentos de incerteza ao longo desse processo de criação.

\section{Aos companheiros de trabalho e amigos:}

À Edú Reis, que em setembro de 2008 integrou a investigação prática desse projeto como um olhar externo para guiar o "caos criativo" de uma atriz em busca incessante. Agradeço pela colaboração fundamental, pela paciência e carinho com que dedicou a este e outras pesquisas que integramos juntos. 
À Carlos Nenê pela música maravilhosa que me proporcionou em uma das fases de minha experimentação e na apresentação em minha banca de Qualificação. Agradeço ainda a presença fundamental no momento decisivo de minha pesquisa, em que pensei em desistir, mas que graças a seu auxílio me possibilitou retornar a pesquisa de maneira ainda mais intensa.

À Jamil Jiorges e Marcos Lemos por terem me presenteado com sua música em uma das apresentações de meu experimento cênico para o Cepeca, coordenado por Armando Sérgio.

À Thais Almeida Prado, Karina Ká e Bianca Zancheta pelos tempos da Cia Oca onde nos sustentavamos nas nossas próprias inquietações e criavamos e pensavamos livremente.

\section{Aos professores:}

Ao professor Armando pelos exercícios e estímulo a minha pesquisa. Pela maneira tão comprometida com que coordena o Cepeca no desencolvimento prático da investigação de cada ator pesquisador. Agradeço ainda a confiança que depositou em meu trabalho.

Ao professor Cassiano Quilici pela presença essencial em minha banca de Qualificação, com orientações que me permitiiram redefinir essa pesquisa e valorizar meu trabalho com interprete-criadora. 


\section{Aos parceiros de vida:}

À Aline Borsari pela amizade infinita, pela presença em todos os momentos marcantes de minha trajetória artística nos últimos três anos em que nos aproximamos. Pelas viagens maravilhosas que fizemos juntas e que foram fundamentais para me renovar em minhas crenças. Agradeço ainda pela imensa paciência com que me aconselhou em todos os momentos de angústia e desânimo. Pela luz e fé que irradiam de sua figura e que contaminam sempre tão positivamente a todos.

À Eliezer Faleiros por toda a paciência e generosas contribuições a meu trabalho de atriz. Pelos conselhos e por "encurtar muitos caminhos" me revelando os "atalhos".

À Carlos Bauzys pela inspiração que me proporcionou na minha vida acima de tudo. Pela presença fundamental em todos os momentos decisivos e de incertezas. Agradeço pelo carinho, companheirismo e partilha de todos os medos, desafios, dúvidas crenças e desejos. 


\section{Resumo}

Essa é uma investigação do corpo do ator que visa explorar o mito e o ritual dentro das artes cênicas. Mito poéticas do corpo é uma busca da potencialização de um corpo múltiplo e despersonalizado. 0 objetivo é descobrir a poesia corpórea de cada ator criador.

A terminologia despersonalização é um conceito aplicado pela cineasta de vanguarda Maya Deren, uma inspiração fundamental para minha investigação teórica e prática.

O treinamento físico e vocal constou com uma série de abordagens corporais que transitam entrem princípios dança e do teatro. O foco primordial é trabalhar com os "estados". Para isso, a observação dos orixás do candomblé em suas festas cerimoniais foram subsídios que vieram a contribuir determinantemente na investigação de algumas corporeidades.

Esse processo de investigação exigiu um "esvaziamento" de energias pessoais - uma despersonalização - para experienciar uma multiplicidade de estados gerados por motes arquetípicos e simbólicos. 


\section{Abstract}

This is an investigation of the actor's body which aims to explore the myth and ritual within the performing arts. Poetic myth of the body is a search for potentiation of a multiple body and despersonalized. The idea is to find the poetry body of each actor creator. The terminology depersonalization is a concept applied by the avantgarde filmmaker Maya Deren, a key inspiration for my theoretical and practical research.

The vocal and physical training consisted of a series of approaches body, passing entering principles of dance and theater. The primary focus is to work with "states". For this reason, the observation of the deities of Candomblé in their ceremonial festivities were subsidies that came to contribute decisively in the investigation of certain corporeities.

This process of investigation required a "emptying" of personal energy a depersonalization - to experience a multitude of states generated by arquetypal headings and symbolic. 


\section{Resumen}

Esta es uma investigación a respecto del cuerpo del actor que se propone a explorar los mitos y el ritual dentro de las artes escénicas.

Mito poéticas del cuerpo es una búsqueda de la potenciación de un cuerpo múltiplo y despersonalizado. La idea es encontrar la poesía corpórea de cada actor creador.

La terminologia despersonalización es un concepto aplicado por la cineasta vanguardista Maya Deren, una clave para mi inspiración e investigación teórica y práctica.

El entrenamiento físico y vocal consistió em uma serie de abordajes corpóreos que transitaban por médio de los princípios de la danza y el teatro. El objetivo principal es trabajar com "aspectos". Por esta razón, la observación de los Orishas del Candomblé en sus festividades ceremoniales fueron los subsidios que trajeron una contribución decisiva en la investigación de algunas corporeidades.

Este proceso de investigación exigió um "vaciamiento" de las energias personales - una despersonalización - para la experiência de uma multitud de estados generados por inspiraciones arquetípicas y simbólicas 


\section{SUMÁRIO}

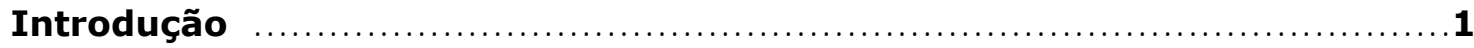

Capítulo 1 - Maya Deren Uma inspiração para o trabalho criativo ...........10

Maya Deren e Trajetória $\ldots \ldots \ldots \ldots \ldots \ldots \ldots \ldots \ldots \ldots \ldots \ldots \ldots \ldots \ldots \ldots \ldots \ldots \ldots \ldots \ldots \ldots$

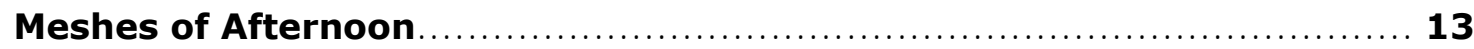

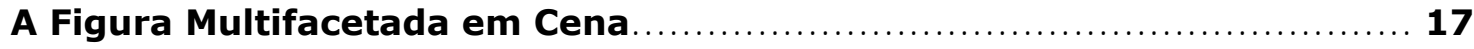

A Despersonalização como elemento do Ritual............................ 18

O transe na Obra de Deren - Estudo Etnográfico do "Voodoo" - Ritual e Mitos

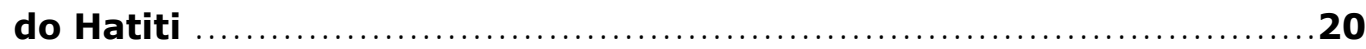

"Anagrama" de Deren/ relação com a construção da cena................ 23

Os Símbolos Elegidos para a Criação - Análise temático e função

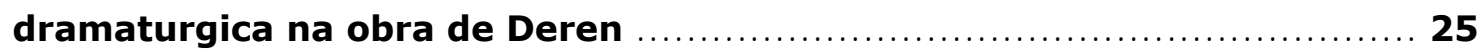

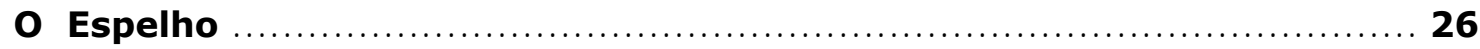

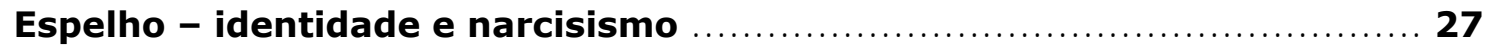

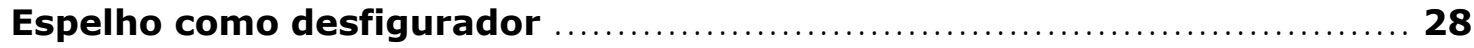

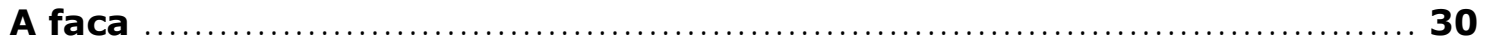

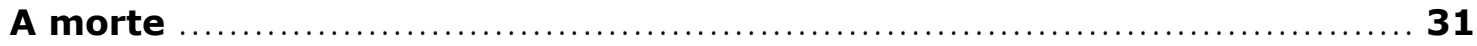

Capítulo 2 - 0 corpo do ator. Um olhar sobre a despersonalização, rito e mito no teatro.

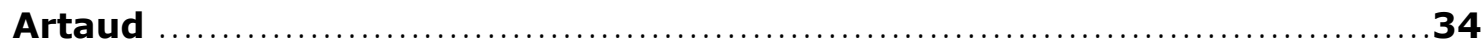

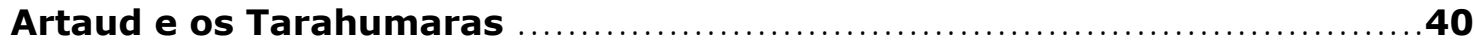


Artaud e o Butoh

Grotowski - Mito, Transe e teatros orientais $\ldots \ldots \ldots \ldots \ldots \ldots \ldots \ldots \ldots \ldots \ldots \ldots 4$

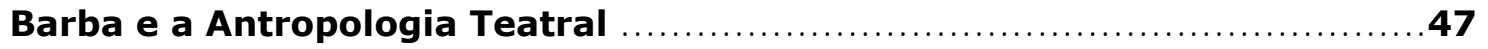

Barba e Considerações sobre o Candomblé $\ldots \ldots \ldots \ldots \ldots \ldots \ldots \ldots \ldots \ldots \ldots \ldots \ldots$

Capítulo 3 - 0 corpo religioso . A despersonalização, rito e mito no

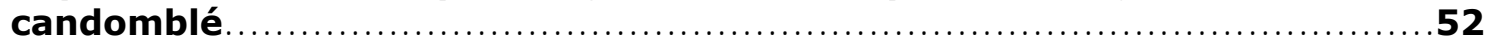

Considerações do Candomblé à Umbanda............................. 54

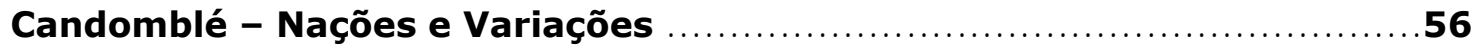

Umbanda - "Uma Religião a Moda Brasileira" . ............................58

O transe - a Despersonalização no Rito Religioso. Noção do Sujeito e Corpo no

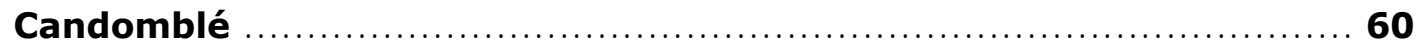

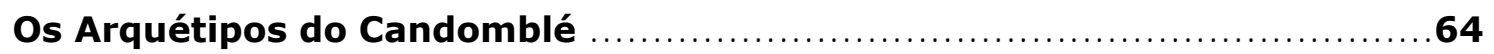

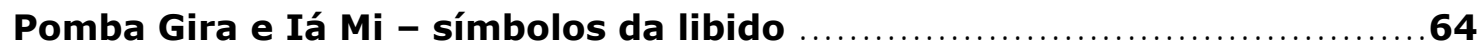

Iá Mi (ou Iá Mi) - o Poder das Mães Ancestrais .........................69

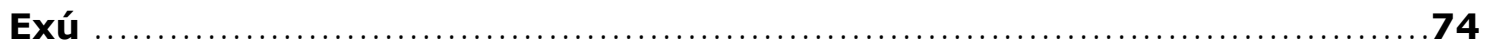

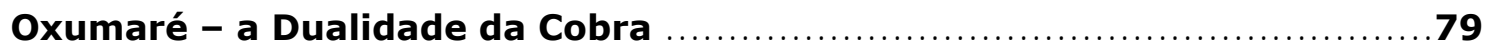

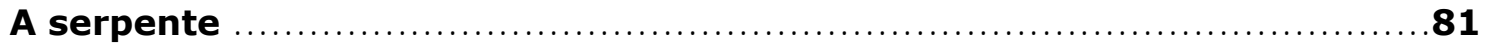

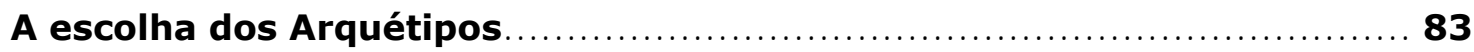

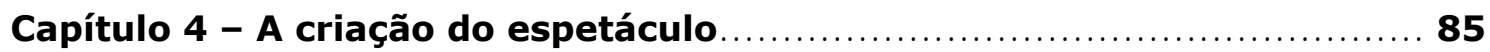

Procedimentos técnicos e metodológicos. Instrumentos de Pesquisa..... 87

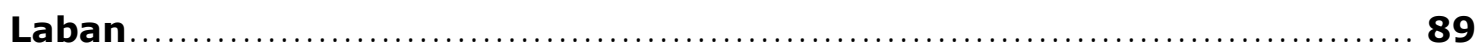

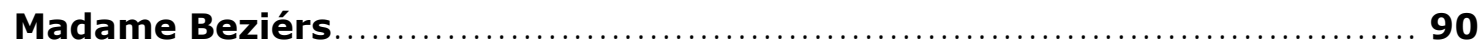

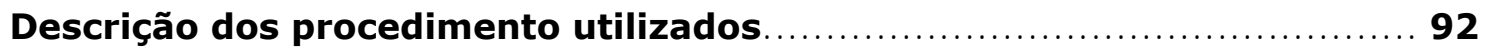

A escolha dos símbolos que permearão a investigação prática. Os universos temáticos dos símbolos inspirados em Meshes of Afternoon.... 92

Exploração corporal dos símbolos estudados $\ldots \ldots \ldots \ldots \ldots \ldots \ldots \ldots \ldots \ldots \ldots . \ldots 3$

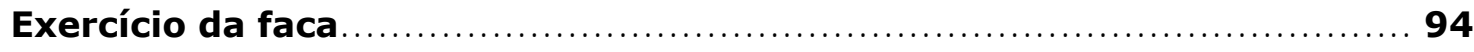


Exercício do Espelho: Circularidade - Exploração do $\infty$ do quadril, costelas e

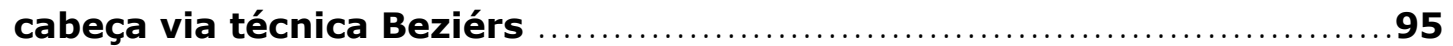

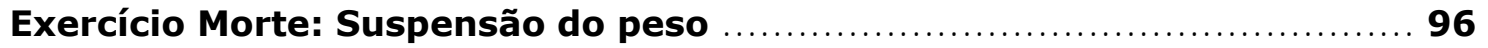

Exploração corporal dos Arquétipos Escolhidos......................... 97

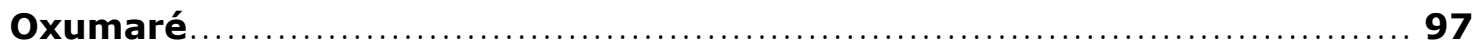

Iá Mi/ Exercício de desaceleração $\ldots \ldots \ldots \ldots \ldots \ldots \ldots \ldots \ldots \ldots \ldots \ldots \ldots \ldots \ldots \ldots, 98$

Exercício de Mapeamento das "Asas" ................................ 99

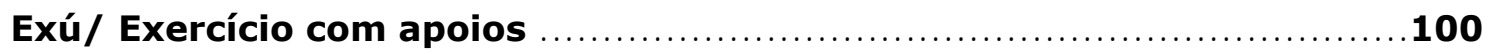

Esquematização do Material em dramaturgia. O mito da Iá Mi o eixo

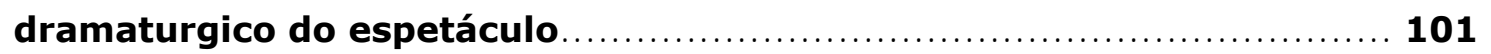

Os Arquétipos - conexão de Iá Mi, exú e Oxumaré na composição da "persona" de cada bloco 105

Os Símbolos Elegidos - influência temática e eixos dramaturgicos na Criação dos Blocos de cena do espetáculo 106

Os 7 tempos, os 7 Ritos de Passagem - relação com os Arquétipos e Símbolos 108

Organização do Texto de Hilda Hilst com o corpo do ator 111

Exercícios com a Palavra, com a Voz 112

Composição do espetáculo 116

Considerações Finais 130

Anexo Mitos e Imagens Inspiradoras 131

Textos de Hilda Hilst - Aparatos Inspiradores........................ 132

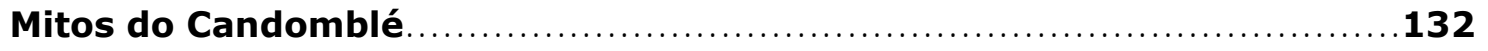

Oxumaré transform-se em cobra para escapar de Xangô $\ldots \ldots \ldots \ldots \ldots \ldots \ldots 132$

Iá Mi reconhece o poder dos homens sobre o poder feminino (Mito da

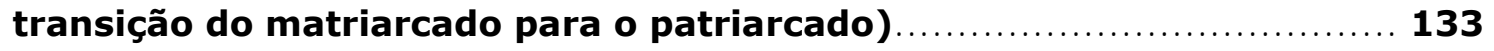

Exu não consegue vencer a Morte .137 
Inspirações Imagéticas 138

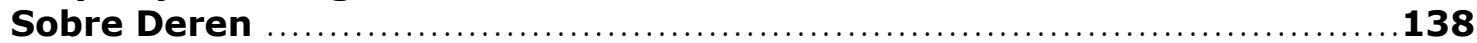

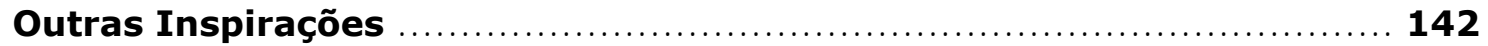

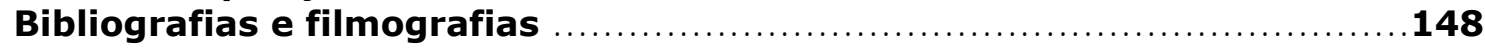




\section{Introdução}




\section{Introdução}

\section{O Percurso}

Quando iniciei meu curso no Mestrado minha pesquisa intitulada Mito poéticas do Corpo visava pesquisar e ampliar a discussão do rito no teatro e construir um corpo múltiplo do ator, no entanto a relação de todos esses conceitos tinha foco em um estudo profundo dos arquétipos das religiões afrobrasileiras. A cineasta Maya Deren e seu filme Meshes of Afternoon foi desde o princípio o mote poético para a criação narrativa da cena. No entanto, as fisicalidades corpóreas que estava investigando não eram sobre os símbolos de seu filme, mas sobre as entidades de umbanda e do candomblé.

Debrucei-me profundamente ao longo do ano de 2006 e 2007 no estudo da religião e freqüentava vários terreiros, entre eles ressalto a importância do "Ilê de Obá de Pai Dessemir" para realizar a investigação prática. Essa experiência era fundamental para a minha pesquisa, pois a observação do fenômeno de incorporação me fez perceber a noção de corpo em êxtase, território do desconhecido - "cavalo-sagrado" de outros seres. Relacionei o estado de possessão ao corpo do ator que desejava investigar, como um ser despersonalizado e canal de múltiplas possibilidades. Essa noção de corpo foi preservada até hoje em minha pesquisa.

O fato é que não consegui, em virtude de meu envolvimento com a religião, manter um olhar científico e distanciado em relação ao meu objeto de 
estudo. O envolvimento se deu de maneira tão intensa que eu vivenciei por diversas vezes o fenômeno do transe e não consegui descrevê-lo cientificamente. Além disso, o material para se pesquisar no candomblé e umbanda é vasto e creio que é motivo para uma tese de doutorado e não de Mestrado. Lançar um olhar sobre a noção de corpo nessas religiões é algo que exige muito estudo prático e teórico ao longo de muitos anos e não seria possível me aprofundar em dois anos. Em virtude desses motivos, mudei no início de 2008 o foco de minha pesquisa. O assunto sempre foi o mesmo, mas a relação que antes era com as religiões afro-brasileiras como um todo passou a ser focada apenas na investigação de fisicalidades de algumas das suas divindades. Com o objetivo de expandir essa discussão sobre o corpo múltiplo enquanto expressão de símbolos e mitos destaquei a interferência do trabalho da cineasta Maya Deren. Essa cineasta experimental da década de 40 me contaminou profundamente na busca de um corpo despersonalizado - sem os confinamentos e as clausuras de uma personalidade. Esse receptáculo carnal capaz de exprimir símbolos e mitos de diversas matrizes culturais contava com a única finalidade de resgatar o sentido ritual ou como Deren falava: "criar uma forma ritualística".

Acredito que a pesquisa emperrava muitas vezes no instante de "mergulho" nesses estados das divindades do candomblé. A dificuldade de trabalhar com um assunto pouco explorado na teoria, como as religiões afrobrasileiras, sobre a perspectiva do ator, que relaciona o seu corpo com a noção desse corpo ritual é algo que me limitou na prática.

Muitos antropólogos fizeram uma vasta pesquisa sobre o candomblé, seus orixás e inclusive a derivação em tipologias, como podemos ressaltar 
Claude Lépine - "Os estereótipos da personalidade no candomblé" ${ }^{1}$. Mas, o foco do trabalho não era de viés antropológico e como não gostaria de relatar algo sem a certeza científica resolvi reduzir a influência do candomblé apenas no que tange a investigação de algumas de suas divindades arquetípicas.

É importante ressaltar que para nós atores que lidamos constantemente com a experiência prática é muito complicado ter que redimensioná-la a normas acadêmicas e estruturas rígidas. Gosto de escrever com liberdade fazendo inúmeras conexões e em virtude das regras da academia apresentei dificuldades de conseguir descrever a experiência prática, ou seja, os procedimentos de criação. É um trabalho exaustivo transpor uma pesquisa que muitas vezes se traduz em uma sensação para a linguagem escrita e inseri-la dentro da práxis acadêmica.

Quando estudava o candomblé em sua vasta complexidade me via com uma limitação ainda maior, pois nem mesmo uma imagem e uma descrição minuciosa são capazes de traduzir o poder que tem uma dança de um orixá. Esses trabalhos ficam superficiais se não forem acompanhados de um material vídeo-gráfico e mesmo assim é insuficiente na reprodução do rito religioso. Afinal, percebo que se faz necessário à referência em sua integridade para depois poder recriá-la e resignificá-la.

Hoje, percebo que há muito a se investigar sobre o corpo ritualístico e estou nesse caminho. De nenhuma maneira posso dizer que desperdicei a minha pesquisa das religiões afro-brasileiras. Ao contrário, ela veio a somar profundamente na noção de corpo do ator que desejo construir. A observação

\footnotetext{
${ }^{1} \mathrm{O}$ estudo aprofundado sobre o tema se encontra na tese de doutoramento de Claude Lépine intitulada “Contribuição ao estudo do sistema de classificação dos tipos psicológicos no candomblé Ketu de Salvador” e apresentada na FFLCH/ USP em 1978.
} 
do ritual no candomblé me proporcionou elementos para a construção de minha própria estética de cena.

Maya Deren pesquisou por muito tempo a religião haitiana Vodu, com procedimentos rituais semelhantes ao candomblé por ser de matriz africana também. Deren fez um documentário sobre a religião e destaca a importância desse estudo na formulação de sua estética e nos conceitos base do seu pensar artístico.

Realmente, me deparei com essa mudança de foco da minha pesquisa e que em alguns momentos me fez pensar em desistir do curso de Mestrado. Mas, atualmente estou plena na realização prática e teórica da mesma, ao apropriar e transformar a experiência anterior ao meu trabalho de atriz.

\section{Objeto da Pesquisa}

Essa investigação visa à construção de um corpo do ator que se ampare nos mitos $^{2}$ como estrutura potencializadora da expressividade cênica. Para isso, utilizarei como anteparo ${ }^{3}$ a referência de elementos da obra da cineasta de vanguarda Maya Deren.

As relações que irei destacar nesse trabalho com a cineasta de vanguarda se evidenciam em filmes como Meshes of Afternoon através da presença do rito, do conceito de despersonalização do interprete e da presença de símbolos interagindo com o corpo do ator na construção da cena.

Quando uso a terminologia símbolo me refiro ao mesmo conceito aplicado

\footnotetext{
${ }^{2}$ Mito não enquanto mitologia, mas enquanto arquétipo.

${ }^{3}$ Anteparo segundo Armando Sérgio da Silva é um estímulo utilizado para a criação da cena. Esse conceito foi defendido na tese de livre docência “Oficina da Essência” no CAC/ USP.
} 
por Jung ${ }^{4}$, como um nome ou uma imagem que nos pode ser familiar na vida diária, embora possua conotações especiais além de seu significado evidente e convencional. Implica alguma coisa vaga, desconhecida, que conduz a idéias que vão além do campo da razão. Assim, uma imagem simbólica é baseada em uma crença, em um mito, mas nunca em uma evidência concreta. É por esse motivo que escolhi o filme Meshes of Afternoon como mote para investigação prática, pois nele há a presença de vários símbolos. Elegi três para explorar na composição dramaturgica da cena, que são: a faca, o espelho (inteiro e estilhaçado) e a morte.

Maya afirma por meio desse filme a sua estética, ao reforçar a experiência de êxtase do corpo por meio de um rito de passagem - a eminência da morte - evocando um arsenal de imagens arquetípicas que operam como signos capazes de acessar o inconsciente de diversas culturas. No entanto, Maya Deren afirma: "Acessar o inconsciente coletivo não significa que o artista deve render-se as formas de criação que utilizam o inconsciente como é o caso dos surrealistas." Ao contrário, Deren defende que a tarefa do cinema bem como qualquer outra forma de arte é não traduzir mensagens ocultas do inconsciente, da alma na arte, mas experimentar os efeitos das técnicas contemporâneas nos nervos, mentes e almas.

Com o enfoque de acessar estados de uma "supra-consciência" e não o inconsciente, que como diria o mestre Antônio Januzelli: "No estado de consciência elevado você se apossa do que te possui". Não se rendendo a abstração vã é que desejo gerar exercícios para despertar essa consciência

\footnotetext{
${ }^{4}$ JUNG. “O Homem e seus Símbolos.” Pág. 20.
} 
sobre a experiência do ritual.

Dessa forma, escolhi em função do trabalho prático, a partir das necessidades e fruição de meu próprio corpo alguns arquétipos do candomblé

e umbanda para alimentar essa pesquisa na busca de um corpo múltiplo e despersonalizado. Os orixás escolhidos foram Oxumaré, exu e lyá Mi. Afinal, para despersonalizar-se Deren propõe o caminho do poeta, da co-existência simultânea de múltiplas forças em um só corpo.

\section{Assunto}

A ação mitopoética é, portanto, uma ação com um objetivo, mas que se processa no campo da metáfora e do arquetípico, construindo assim uma nova noção do ator, como alguém que opera atos simbólicos e rituais. A idéia de corpo do interprete - criador que proponho não processa ações cotidianas, pois ele explora o máximo de sua expressividade e plasticidade, podendo significar ou mimetizar os movimentos de um animal, por exemplo.

O conceito de corporal que desejo trabalhar é de um corpo vazio, despersonalizado, que assim como em uma possessão é um canal aberto para diversas potências míticas.

O foco dessa metodologia é buscar nesse corpo múltiplo o universo de mitos, de sua poética pessoal, que o singularizam como criador e propiciam a composição uma estética pessoal. Assim, a ação mitopoética gera um universo paralelo de múltiplos significados, que friccionados com uma música, um texto, ou uma poesia, constroem possibilidades de uma compreensão de cena que 
vão além de padrões de pensamento e códigos de ações sociais ou culturais, rompendo assim com algumas molaridades ${ }^{5}$.

O corpo é cheio de simbolismos e o movimento é organizado segundo valores pessoais, culturais, emoções e estilos de dança. Esse histórico de referências individuais que vão além das molaridades é o que faz com que cada corpo imprima em seu movimento a sua personalidade. Ao pensar em personalidade como valores e traços que imprimem uma imagem pessoal é que concluímos que cada corpo constrói uma forma de expressar-se - uma poética pessoal - com base em conteúdos íntimos e intransferíveis. Quando me refiro ao conceito que Maya Deren utiliza de despersonalização não me refiro a abolir a impressão digital do ator, a sua estética e poética, mas a buscar um estado corpóreo de criação que possibilite a gestação de diversas potências em um só corpo.

Na pesquisa de Stanley Keleman ${ }^{6}$ ele afirma que cada homem vive um mito. Sobre essa perspectiva podemos pensar em construir uma mitopoética pessoal de cada corpo.

\footnotetext{
${ }^{5}$ Os estratos são adensamentos, formas de espessamento, dobras, pinças, coagulações, sedimentações, que podem ser molares ou moleculares, coletivos ou singulares. (Deleuze e Gattari. Capitalismo e a Esquizofrênia.Vol. 5 Pág. 216).

${ }^{6}$ Keleman, Mito e Corpo, 2001.
} 


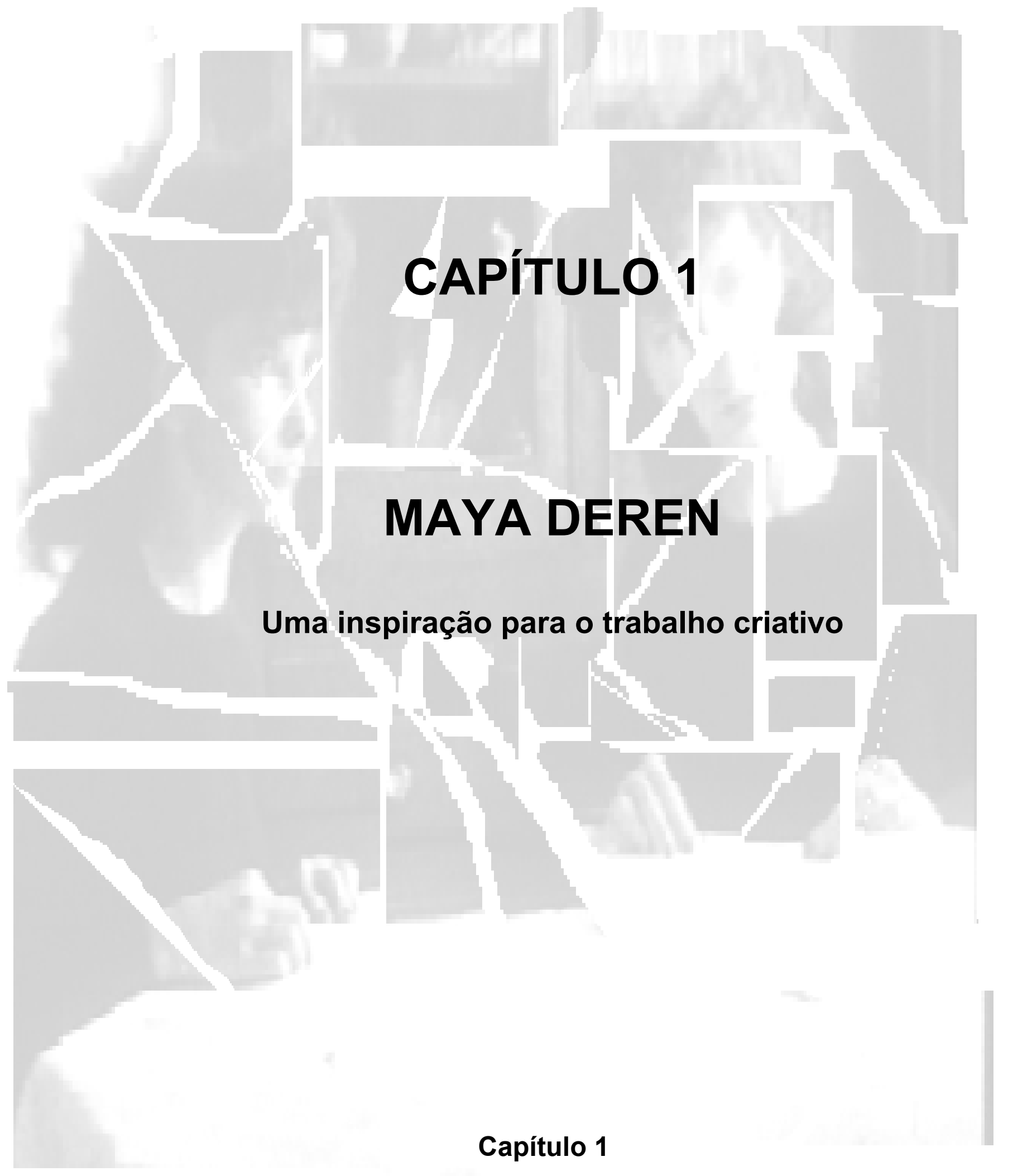




\section{MAYA DEREN}

\section{Uma inspiração para o trabalho criativo}

Nesse capítulo destrincharei alguns aspectos sobre a obra de Maya Deren e sua influência em minha trajetória de atriz pesquisadora. Gostaria de ressaltar que essa não é uma dissertação que se dedica a fazer uma profunda investigação sobre essa importante figura na história do cinema e da vídeodança. Meu objetivo é apenas contextualizar a importância dessa artista como fomentadora de inquietações, conceitos e reverberações em meu fazer artístico.

Abordaremos, portanto, nesse capítulo a influência da obra cinematográfica "Meshes of Afternoon" na elaboração de minha criação artística. A presença de alguns símbolos dessa narrativa cinematográfica se tornam motes inspiradores fundamentais na construção do corpo cênico e na dramaturgia do espetáculo.

$\mathrm{Na}$ trajetória artística de Deren na dança, cinema e pesquisa são arquitetados princípios fundamentais que norteiam o seu trabalho como criadora: a despersonalização, o Anagrama e a "forma ritualística". Esses fundamentos serão abordados nesse capítulo com detalhamento, pois serão objetos de estudo centrais na aplicação prática dessa pesquisa, que resultará na composição de um espetáculo. 


\section{Maya Deren e Trajetória}

Maya Deren é uma das figuras centrais do cinema de vanguarda nos EUA nos anos 40 e 50. Além de ser também bailarina, coreógrafa, poeta, escritora e fotógrafa. No cinema era diretora, atriz, roteirista, editora, performer e pioneira do cinema experimental nos Estados Unidos. Nascida em Kiev, na Ucrânia, em 1917, Eleonora Derenkovskaya (seu nome verdadeiro) transferiu-se para os EUA com sua família em 1922. A mudança foi motivada pela precária situação econômica da URSS na época (que empobreceu a até então rica família judia), pela perseguição aos partidários de Trotsky (como era o caso de seu pai) e pela prática do "pogrom" no país (linchamento de judeus praticado por nacionalistas russos no final do século 19 e início do século 20).

Além de atuar em clássicos do cinema experimental, como Meshes of the Afternoon (1943), At Land (1944), A Study in Choreography for Camera (1945) e Ritual in a Transfigured Time (1946), Maya Deren enriqueceu sua biografia ao envolver-se profundamente com o estudo e a prática do vodu. Realizou o documentário da religião haitiana em "Gods of Haiti", de 55, inacabado e somente finalizado em 77 por Teiji Ito (seu último marido).

O feminismo em Deren aparece não só como uma questão de luta da época, mas como investigação de importantes questões da identidade da mulher no universo masculino, e principalmente no cinema.

Simultaneamente, Deren trabalhava na famosa companhia de dança de Katherine Dunham, o que motivou vários de seus filmes nos quais expressa o 
movimento e a expressão corporal, entre eles "Ritual in Transfigured Time". A influência da dança e o caráter ritualístico se reflete em filmes como "A Study in Choreography for Camera" que estabelece uma relação original entre tempo e espaço; "The Very Eye of Night", no qual a diretora se vale de bailarinos para criar imagens em negativo; e "Meditation on Violence", cujo tema são as práticas milenares de duas escolas de artes marciais chinesas.

Maya Deren morreu em 1961 de hemorragia cerebral, desencadeada por uma dependência de anfetaminas e comprimidos para dormir, mas alguns explicam que ela foi vítima de um rito de vodu.

Seu masterpiece foi o "Meshes of the Afternoon" (1943), um estranho e analítico filme experimental enumerado entre outras obras prioritariamente preocupadas em exibir o realismo da imagem (cinematografia/fotografia), na junção de forma, técnica e conteúdo em cinema narrativo. A ênfase do trabalho de Maya era a subversão das noções de tempo e realidade, com jogos de câmera para causar estranheza, em contrapartida ao standard "cru" do cine documentário.

Meshes of Afternoon foi produzido em um ambiente de Guerra e volatilidade e isso se reflete na encenação. O filme estabelece uma atmosfera saturada na paranóia e na desconfiança que faz com que amantes se transformem em assassinos e com a presença de uma fascinante e misteriosa figura encapuzada. Como imigrantes europeus, Deren e seu segundo marido (Hammid) investiram em seu filme um agudo senso de inquietação e alienação. No filme a figura central se duplica, triplica e quadruplica em uma narrativa cíclica, que parece condenada a repetição. A figura encapuzada com a face reflexiva (possui um espelho na face) e adiciona outra dimensão, retornando a 
identidade para aquele que a olha nos olhos.

Meshes of Afternoon é um filme silencioso, sem diálogos, comunicação entre seus personagens e som direto. Teiji Ito fez a trilha do filme após a morte de Deren. Os sons dos passos de Deren são metonimicamente acompanhados pela percussão de Teiji Ito. A trilha foi inspirada na noção de Eisenstein de montagem rítmica ${ }^{7}$.

Ritmo é o elemento definitivo dos filmes de Deren, ele surge da repetição e variação de seus experimentos narrativos. Meshes instala um estilo inovador por cortar a ação quando os passos da protagonista passam por terrenos desiguais como a praia, a terra, a grama e o concreto. $\mathrm{O}$ ritmo do atabaque marca a descontinuidade espacial, a lacuna de tempo. Meshes of Afternoon é como a encenação de um sonho, uma trajetória narrativa ilógica, em que o fluxo de movimento e a atmosfera convidam à contemplação e a transcendência, envolvendo o espectador.

\section{Meshes of Afternoon}

A escolha desse filme em específico para pautar a construção da encenação e da pesquisa prática se deve em função dos símbolos que o permeiam: a faca, o espelho e a morte. Em outros curtas-metragens de Deren verificamos a presença de elementos rituais e o uso da expressividade corporal como em uma "dança ritual", mas em Meshes of Afternoon existe uma temática

\footnotetext{
${ }^{7}$ Eisenstein permaneceu cometido à visão de que o cinema é um espetáculo calculado para o espectador. (Bordwell, Narration on fiction film, pg 14).
} 
que me interessa: o duplo, o triplo, a multiplicação de uma mesma figura em várias personas.

A protagonista de Meshes of Afternoon volta a sua casa e percebe um caos doméstico, uma atmosfera de paranóia e desordem faz com que se sucedam diversas cenas onde a protagonista se relaciona com objetos animados e transformacionais, com uma figura encapuzada e com seus vários selfs, que se multiplicam.

Na famosa cena da mesa vemos a figura principal multiplicada em quatro, e nesse momento perdemos a noção de quem é o elemento central e os duplos, pois todas passam a ter a mesma importância, revelando facetas da mesma pessoa que desconhecíamos. Ao realizar esse filme, Deren rompe com a idéia de narrativa linear e constrói uma figura múltipla de potencialidades, inserindo-a em um estado liminal, de potência,de caos e de passagem.

Não há como mapear as sensações da protagonista de Meshes of Afternoon em uma única fisicalidade, uma vez que ela está em uma zona de turbulência e diferentes corporeidades são somadas na construção de seu caráter.

Na seqüência da mesa em que a mulher se multiplica em quatro encarnações dela mesma, Deren faz menção a um ritual africano "julgamento do fogo" em que cada uma das mulheres toca uma chave, que se transforma numa faca. Tais referências aos rituais, como as referências aos jogos são outro padrão externo que Deren visa incorporar em seu trabalho.

Os jogos de infância são outro caminho que Deren escolheu para ligar a sua arte com os rituais que todos nós experimentamos inocentemente e participamos profundamente. O jogo infantil "O que há de errado com essa 
figura?" revela a atmosfera de Meshes of Afternoon, um ambiente de desordem doméstica onde os objetos parecem ter vida e aparecem fora do lugar. Uma chave se torna uma palavra, saída da boca da artista, a mesma chave se transforma em uma faca e uma flor. A faca aparece na cama, o telefone fora do gancho e a chave sai da boca, como evidências do caos do ambiente.

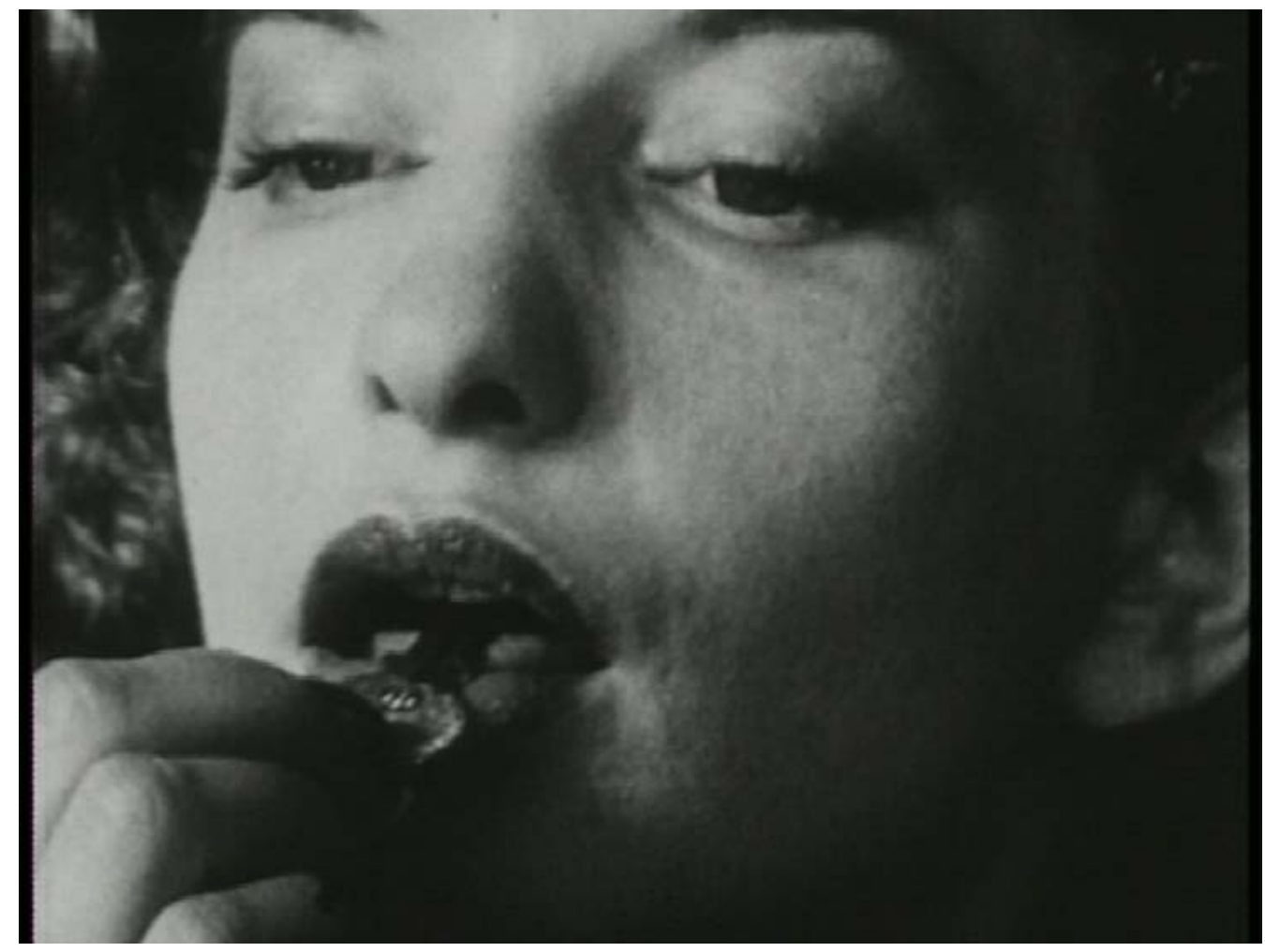

A chave que saí da boca em Meshes of Afternoon

Em Meshes muitas possibilidades co-existem enredadas, assim uma única interpretação não pode dominar esse filme. A forma da morte toma um caráter diferente no fim do filme. Em Meshes o mar não cobre e reivindica o seu cadáver. A imagem da morte é dada na poltrona da própria sala de estar. Mas, o espectador não consegue tomar isso por um fim. A mulher que lança seu corpo na poltrona e fecha seus olhos num sonho que nunca acorda com o beijo do amante para um final simples. Ao invés de acordar, o beijo de contos de 
fada, inserido no meio do sonho é o propulsor de uma reação violenta que conduzirá para a imagem da morte. A violência da faca pela face do homem, que só sucede em atingir um espelho conecta a sala com o litoral como lugar da morte. O golpe no espelho permite ao mar emergir das profundezas e precipitar na praia cobrindo os estilhaços do espelho.

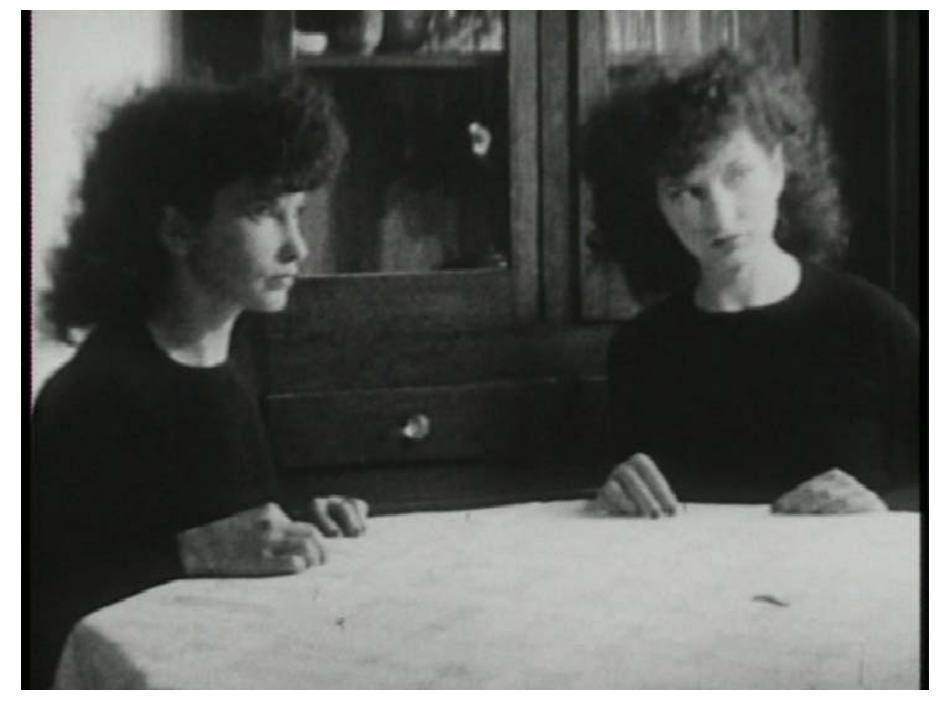

Cena da Multiplicação em Meshes of Afternoon

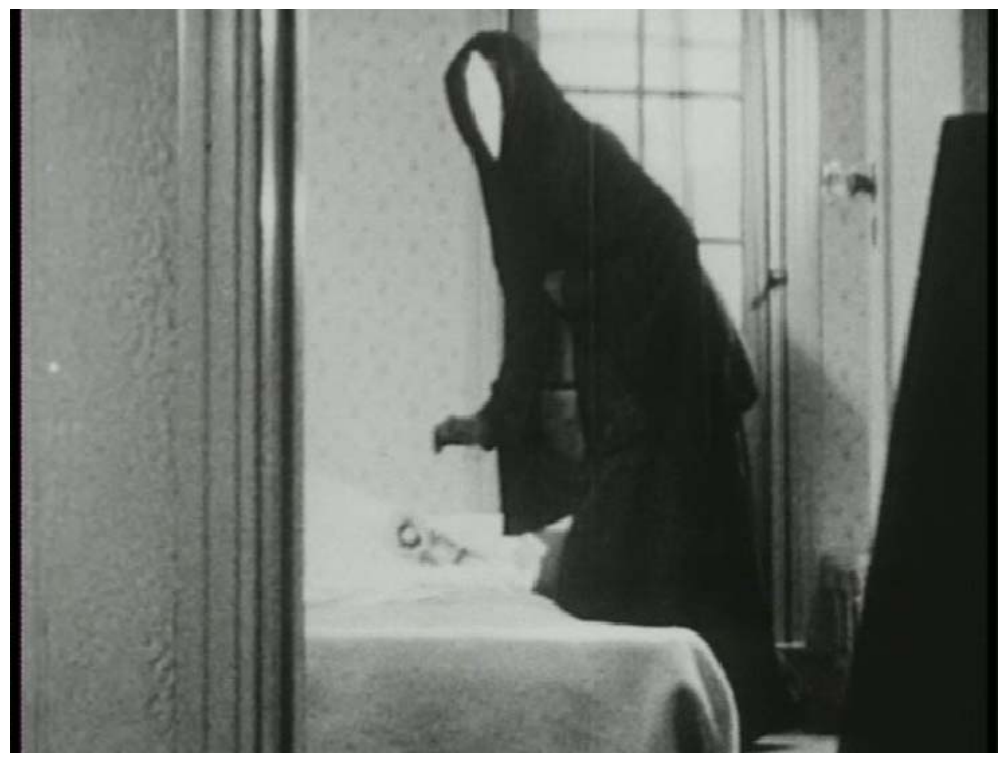

Figura da Morte em Meshes of Afternoon 


\section{A Figura Multifacetada em Cena}

A construção dos estados que permeiam minha figura foram calcadas nas três matrizes simbólicas do filme Meshes of Afternoon - faca, espelho e morte que funcionam como elo dramaturgico. Dessa base se elaboram também alguns estados e ações presentes na cena.

As corporeidades em Meshes se afetam mutuamente, pois trabalham numa zona de fronteira, somando para construir novos significados presentes no mesmo corpo, um corpo múltiplo de qualidades que interagem entre si e que por conseqüência gerará uma figura múltipla.

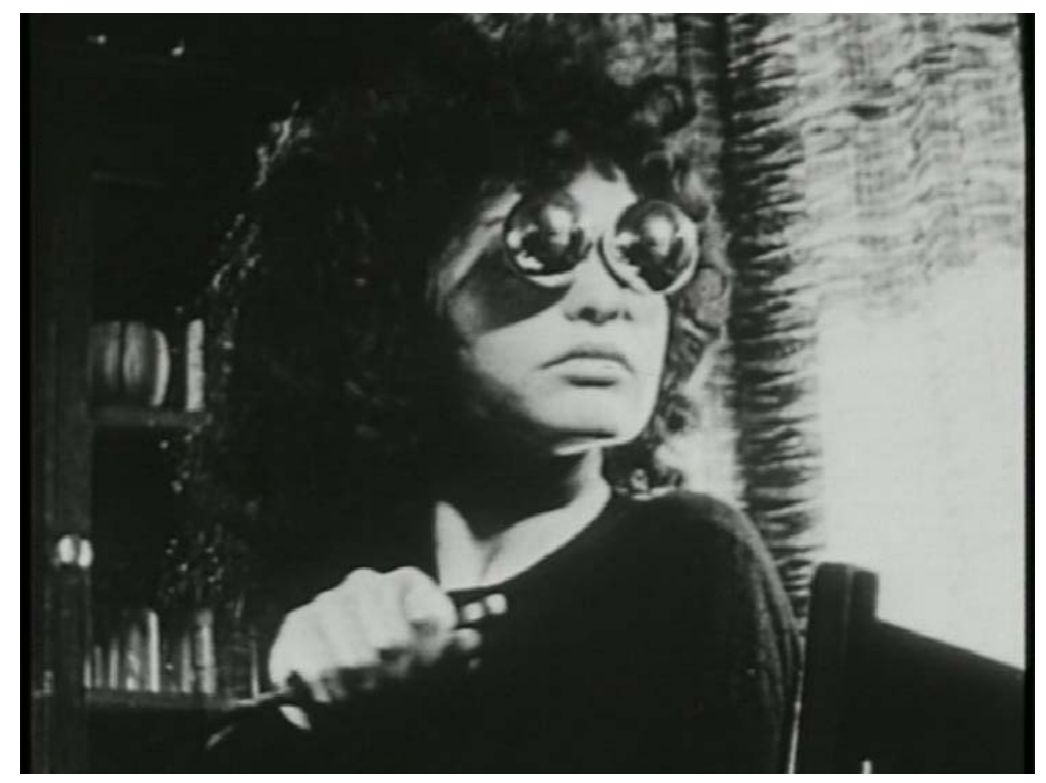

Uma das figuras construídas por Deren em Meshes of Afternoon

Deren considera em seu filme que não existem personagens, pois assume que para o poeta ou o ator é mais interessante fugir da tendência à personalização, pois a multiplicidade da despersonalização é uma fonte criativa 
maior. A visão de Deren sobre a subjetividade individual e expressão estética confere com a de T. S. Eliot's, que afirma em "Tradicion and the Individual Talent":

"O ponto de vista que eu estou batalhando para atacar é talvez relacionado à teoria metafísica da unidade essencial da alma; mas para meu entendimento, o poeta, não tem uma personalidade para expressar, mas um meio particular, em que a impressão e a experiência se combinam em peculiares e inesperáveis caminhos. Poesia não é perder a emoção, mas escapar da emoção, não é a expressão da personalidade, mas a ausência da personalidade." 8

Deren fez seus filmes não de acordo com a lógica de um caráter literal, mas de acordo com leis cinemáticas de espaço, tempo e movimento. Ela chama de forma ritualística :

"Sobre todas, a forma ritualística trata o ser humano não como sendo o centro da ação dramática, mas como um elemento despersonalizado no todo dramático. O intento de tal despersonalização não é destruir o individual, pelo contrário, é engrandecê-lo além da dimensão pessoal e libertá-lo das especializações e confinações da personalidade. “9

\section{A Despersonalização como elemento do Ritual}

Deren chamava o seu método de construção dos filmes de ritualístico. Esse fato se deve a Deren privilegiar em seus filmes a dimensão do tempo, espaço e movimento ao invés da linearidade conferida por uma trama de

\footnotetext{
${ }^{8}$ Michelson, "Poetics and Savage Thought: About Anagram". Maya Deren and the American Avant-Garde. Pg. 33.

${ }^{9}$ Deren, An Anagram, of Ideas on Art, Form and Film, pg. 20
} 
personagens. A persona, como podemos nomear, presente nos filmes de Maya Deren e que em grande parte das vezes era interpretada por ela mesma, é uma figura sempre situada em um momento de passagem. Os filmes como Meshes of Afternoon, At Land e Ritual in a Transfigured Time não garantem nenhuma estabilidade aos seus protagonistas, pois a ênfase é no ritual, na liminaridade e transição, ao invés da permanência. Nessa trilogia, por Deren representadas como atriz, nos deparamos em todas com uma mulher no estado liminal que refuta ser definida como homem ou mulher. O nível de despersonalização é tal que rompe com a idéia de sexo, ao ampliar o ritual além do limite dos gêneros. Maria Pramaggiore faz uma leitura dos filmes de Deren como bissexuais. ${ }^{10}$ Uma relação que não se refere à sexualidade do autor ou do personagem, mas justamente a característica de despersonalização conferida em um ritual. Esse argumento, segundo Pramaggiore, de que o filme convida a uma leitura bissexual reside no fato de que não há clareza entre a identificação e desejo entre os caracteres e potencialmente entre os caracteres e os espectadores. Portanto, a indeterminância do tempo e espaço que não progridem a uma resolução admitem a possibilidade de contingentes identidades, ou sujeitos em processo.

Esse estado liminal em que se encontram as figuras dos filmes de Deren é um dos estágios de um ritual ou rito de passagem descritos por Turner.

Victor Turner considera o ritual como agente de mudança e destaca o

\footnotetext{
${ }^{10}$ Pramaggiore, "Seeing Double”. Maya Deren and The American Avant-garde. Pg.241

${ }^{11}$ Turner, “The Ritual Process: Structure and Anti-Structure.” 1969.
} 
estágio liminal. Essa fase do ritual consiste em uma das três etapas dos ritos de passagem: a separação (afastamento do indivíduo da estrutura social ou de referencias culturais conhecidas), liminaridade ou estado liminal (estado de ambigüidade, de transição) e re-agregação (à volta estrutura de maneira transformada). Nas palavras de Turner:

" Liminaridade pode ser talvez descrita como um produtivo caos, uma ausência fértil, um armazém de possibilidades, de maneira nenhuma uma organização ao acaso, mas uma busca de novas formas e estruturas, um processo em gestação, uma fecundação de modo apropriado antecipando uma existência pós liminar." ${ }^{11}$

Essa liminaridade é uma das características que conferem uma noção de desestruturação da noção de sujeito e se nos utilizarmos da metáfora dos espelhos partidos, podemos analisar essas "personas" de Deren como sujeitos em processo, em densa transição, ao longo desses três filmes.

\section{O transe na Obra de Deren - Estudo Etnográfico do "Vodu" - Ritual e Mitos do Haiti}

Maya Deren realizou em 1946 um estudo profundo sobre a religião haitiana Vodu que resultou no documentário "Divine Horsemen: The Living Gods of Haiti". Ela penetrou a cultura haitiana para perceber que ela estava lidando com uma forma que definia os limites de sua própria estética. $\mathrm{Na}$ realização a dança haitiana se torna algo maior do que uma forma de dança, 
mas algo mais amplo, um ritual mitológico.

O vodu apresenta uma forte conexão com os preceitos do candomblé e se enquadra dentro de uma religião de matriz africana por seu caráter ritualístico, por suas divindades arquetípicas, por a dança ritual e por o fenômeno da possessão. O foco inicial de Deren estava justamente na "personalidade do possuído", mas em Divine Horsemen ela assume que a individualidade do "cavalo" é completamente anulada durante a possessão.

Deren e Graham eram ambas engajadas no discurso modernista que conectava raça e nacionalismo. Graham associou a dança africana com o ritmo de desintegração.

" A dança do negro é uma dança em direção a liberdade, a dança do esquecimento, sempre dionisíaca em seu abandono e esplendor cru do ritmo - é um ritmo de desintegração." 12

Ao examinar as técnicas do transe e os efeitos que tem na percepção e consciência, Deren conclui:

" Tais como vários recursos mecânicos tais como cristais e luzes empregados no hipnotismo, assim, eu acredito que o ritmo percussivos são extremamente importantes ao induzir a possessão.

Como nós sabemos, o ritmo consiste na regularidade de intervalos entre sons. Uma vez que esse intervalo é estabelecido, nossa percepção sensória gera uma expectativa de sua recorrência. Ainda mais importante, sustentar a regularidade rítmica que a fonte é fora do

\footnotetext{
${ }^{12}$ Franko, “Aesthetic Agencies in Flux” Maya Deren and the American Avant-Garde, pg. 135.
} 
individual ao invés de dentro, significa que a consciência é desnecessária, como é, na manutenção da concentração." ${ }^{13}$

Com o entendimento da inconsciência e seu entendimento técnico, Deren engrandece o uso antropológico do termo "ritual".

"Rituais são eventos coletivos com leis comuns de espaço e tempo, que não simplesmente terminam no êxtase e dissolvem a pessoa de seu ser social, ao contrário, durante semelhante processo anárquico do ritual, os participantes são transformados dentro de um novo status social" ${ }^{14}$

Enquanto o corpo dos participantes dançam e tremem em seu estado de inconsciência, as mesmas técnicas que afetam os seus sistemas nervosos irão implantar novos significados culturais e identidades sociais.

O interesse de Deren no Vodu é associado a "encruzilhada" - a figura central do discurso ritualístico haitiano. No Vodu a encruzilhada representa a intersecção entre dois mundos. No ritual haitiano o fenômeno da possessão anula a personalidade da pessoa e faz com que o corpo seja um receptáculo dos $\operatorname{loas}^{15}$ (deuses do vodu).

Em filmes de Deren como "Ritual in Transfigured Time" e "The Very Eye of Night" Deren usa um recurso de imagens negativas. Essa iniciativa de inserir figuras no escuro foi uma correspondência feita pela cineasta com o mito do vodu ao simbolizar o "abismo", o lar permanente dos loas, localizado no fundo do mar. A escuridão foi utilizada por Deren também como uma metáfora do

\footnotetext{
${ }^{13}$ Holl. "Moving the Dancer's Souls". Maya Deren and the American Avant Gard. pg 159.

${ }^{14}$ Michelson, Poetics and Savage Thought: About Anagram. pg. 40.

${ }^{15}$ Loas são as divindades do Voodoo. Habitam as profundezas abissais do mar.
} 
processo em que o indivíduo tenta encontrar sua própria divindade, um princípio dentro do Vodu.

Deren filmou os movimentos de dança e rituais do vodu em slow motion com objetivo de delinear claramente a ação do corpo em seus principais estados. Com a exatidão de uma artista-pesquisadora ela cartografou os domínios interiores e exteriores dessa experiência.

Esse estudo antropológico de Deren se transformou em um documentário e foi definitivo para o aprofundamento de sua estética, funcionado como pilar de seu método ritualístico.

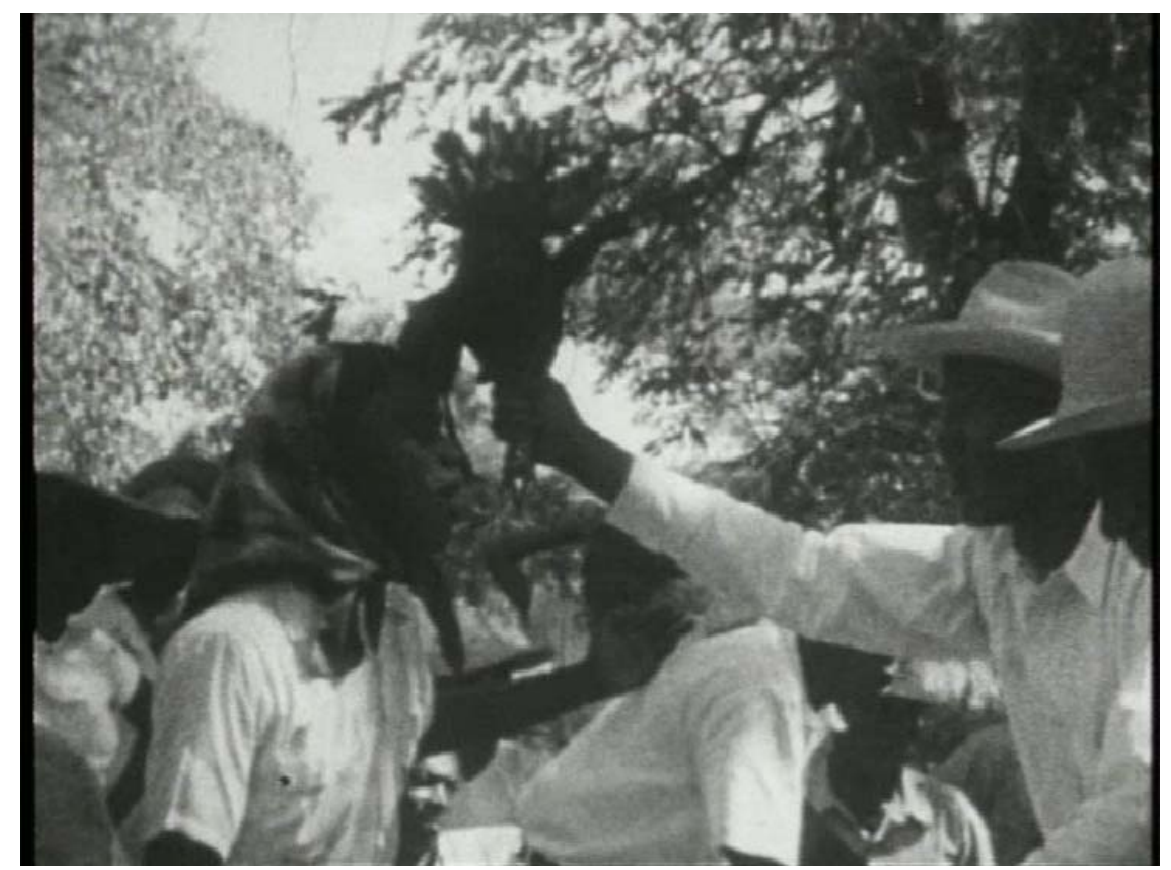

Rito de Oferenda na cerimônia do Vodu - cena do documentário "Divine Horsemen: The Living Gods of Haiti" filmado por Deren no Haiti. 


\section{“Anagrama" de Deren/ relação com a construção da cena}

Um ano depois da sua primeira viagem ao Haiti, Deren escreveu "An Anagram of Ideas on Art, Form and Film" em que ela analisou a ruptura da consciência causada pela divisão da magia, ciência, religião e filosofia século no século XVII e seu efeito na arte.

Deren argumenta que o processo de criação do artista/mágico e do cientista são similares: o ato de fazer o invisível se tornar visível. Agrupando uma rica visão metafísica, Deren trabalhou para combinar elementos do ritual, mito e dança na linguagem cinematográfica e representação escrita.

Segundo Moira Sullivan, uma pesquisadora de Deren "O Anagrama pode ser visualizado por uma série de gelos flutuando no mar aberto. O viajante pode se mover de um gelo para outro mantendo sua jornada em movimento, mas ao permanecer em uma peça por muito tempo resultará no isolamento. A chave reside em ligar as partes com o todo". ${ }^{16}$

"O todo é relacionado com cada parte" escreveu Deren no Anagrama, “assim pode-se ler horizontalmente, verticalmente, diagonalmente, ou mesmo de trás pra frente, a lógica do todo não é rompida e permanece intacta". ${ }^{17}$

Deren defende a poética "vertical" em oposição a "horizontal" ao não se prender a noção lógica de um tempo contínuo como em uma narrativa linear em que um acontecimento sucede ao outro em uma relação de causa e conseqüência. Na narrativa vertical presenciamos a lógica da simultaneidade -

\footnotetext{
${ }^{16}$ Sullivan. "Deren's Ethnographic Representation of Haiti." Maya Deren and the American Avant Gard. pg. 208.

${ }^{17}$ Deren, "An Anagram of Ideas on Art, Form and Film". Maya Deren and the American Avant Gard. pg. 5.
} 
rizomática ${ }^{18}$. A noção vertical de tempo transforma a antítese em ambigüidade, o sucessivo, em descontínuo.

Bachelard em "A Intuição do Instante" amplia a idéia do historiador francês Gaston Roupanel em parte de um dos seus estudos mais importantes Siloe - que propõe um olhar sobre a história numa perspectiva de tempo descontinuada - em instantes. Nessa obra Bachelard define o tempo poético como um tempo andrógino, onde princípios femininos e masculinos coexistem, ao provocar uma relação dual. Deren compartilha dessa visão descontínua do tempo que não segue uma cadeia lógica e natural, pois os fragmentos são instantes autônomos compondo o todo.

" O anagrama é uma combinação de letras em tal relacionamento que cada uma é um elemento simultâneo ao contrário de uma série linear... Consequentemente, nenhum é o primeiro, nenhum é o último, nada é futuro e nada é passado, nada é velho e nada é novo..." 19

Deren atribui a seu método ritualístico uma manipulação consciente pela eliminação do que ela chama de "expressão espontânea" ou representação realista.

O Anagrama como Deren mesmo fez questão de assumir não é um manifesto, mas uma organização de idéias, um complexo anagramático, ao invés de uma lógica linear, como estamos acostumados.

\section{Os Símbolos Elegidos para a Criação - Análise temático e função}

\footnotetext{
${ }^{18}$ Qualquer ponto de um rizoma pode ser conectado a qualquer outro e pode sê-lo. É muito diferente da árvore ou da raiz que fixam um ponto, uma ordem...As multiplicidades são rizomáticas (...) O rizoma é mapa, não decalque. (...) O mapa é aberto, é conectável em todas as dimensões, desmontável, reversível, suscetível de receber modificações constantemente. (Deleuze e Gatarri, Capitalismo e Esquizofrênia, Vol. 5 , pg 15-32)

${ }^{19}$ Deren, "An Anagram of Ideas on Art, Form and Film". Maya Deren and the American Avant Gard. pg. 06.
} 


\section{dramaturgica na obra de Deren}

Os símbolos são os ícones estruturadores do universo temático do filme Meshes of Afternoon. A presença do símbolo é fundamental na composição da linha narrativa, linha que não se processa num tempo "horizontal", como Deren denomina, num plano linear de sucessão, mas sobre uma perspectiva "vertical" de simultaneidade e descontinuidade. As lacunas do filme, suas repetições ganham força e se constituem numa narrativa em que se cria um sentido porque os símbolos são o "elo", a costura entre os fragmentos do filme. O símbolo é o esqueleto do filme, que propõe o sentido às cenas e conecta-as entre si. A relação da "persona" de Meshes com a faca, a morte e os espelhos é que determina a narrativa de Meshes of Afternoon

Nessa perspectiva, utilizo os símbolos da faca, espelhos e morte como motes inspiradores da composição das cenas que formarão o espetáculo resultado dessa pesquisa. Eles serão a fonte geradora da narrativa cênica, o tema provocador da trajetória dessa "figura" no espetáculo. Os símbolos, assim como em Meshes, serão nessa investigação os motes poéticos e o eixo central condutor da dramaturgia.

Para entendermos melhor o universo contido em cada símbolo, explanaremos abaixo sobre seus fundamentos geradores e relacionaremos sua presença em Meshes of Afternoon e as significações por ele provocadas.

\section{O Espelho}

O espelho simboliza a identidade, a vaidade, a contemplação da sexualidade. Em outro momento o espelho constrói um símbolo inverso - o 
espelho partido - ícone da desestruturação do ego, da vaidade, a metáfora da

perda da identidade, do estilhaçamento do ser. Essa dualidade do espelho inteiro e partido é essencial para compreender os dois momentos da personagem de Meshes, que rompe drasticamente uma relação de feminilidade para caminhar a loucura, ao caos e a ausência de identidade.

\section{Espelho - identidade e narcisismo}

Os escritos de Lacan sobre a fase do espelho o caracterizam o objeto de contemplação como um fenômeno limiar, que demarca as fronteiras entre o imaginário e o simbólico. ${ }^{20}$

O espelho registra fielmente aquilo que o atinge. O espelho não interpreta os objetos que reflete, ele simplesmente revela a verdade. Ele gera um "eu especular" sem distorções. Confiamos nos espelhos assim como confiamos nos órgãos perceptivos.

O espelho pode assumir também conotações narcisistas. $O$ espelho de Oxum $^{21}$ no candomblé, por exemplo, é símbolo da vaidade, da contemplação da beleza, evidenciando a sensualidade e o narcisismo.

O espelho como metáfora da identidade aparece em Meshes na reflexão da "persona masculina" que aparece no fim do filme e na face da morte. O elemento masculino e a morte são as manifestações da obra que possuem unidade e forma, se projetando em um campo da realidade, em contraponto

\footnotetext{
${ }^{20}$ No momento em que se delineia a "virada” do eu especular para o eu social, o espelho é a "encruzilhada estrutural” ou, como dizíamos, fenômeno-limiar. Eco. 1989. p 13

${ }^{21}$ Orixá feminino do candomblé símbolo da vaidade e beleza. ( Silva, Candomblé e umbanda: Os Caminhos da Devoção Brasileira. pg. 78) Oxum é símbolo da vaidade narcísica. Porta sempre um espelho na mão.
} 
com a "persona feminina" que sempre é refletida de maneira distorcida, se projetando, por sua vez, em um plano ficcional.

\section{Espelho como desfigurador}

Em outro momento o espelho constrói um símbolo inverso - o espelho partido - ícone da desestruturação da identidade, da vaidade, a metáfora do estilhaçamento do ser. Essa dualidade do espelho inteiro e partido é essencial para compreender os dois momentos da personagem, que rompe drasticamente uma relação de feminilidade para caminhar a androginia.

O espelho partido como ícone desse estilhaçamento do "eu", de dissolução do ego convida para o mergulho nesse abismo de potencialidades infinitas que nos habitam. Nesse sentido, esse estilhaçar da identidade é um rito de passagem por uma zona de turbulência, onde linhas de fuga ${ }^{22}$, como se refere Deleuze e Focault, nos conduzem para uma zona de potências. Esse momento de transição, da perda da identidade é sempre seguido de uma sensação de ausência - de uma não-forma, nos provocando um fenômeno de desterritorialização. Esse desenraizar-se nos lança no universo de potencialidades múltiplas que nos habitam. Nos ritos de passagem a metáfora do espelho partido é a do vazio, do abismo de possibilidades, do caos que antecede a morte.

O símbolo do espelho destroçado corresponde às partes do eu que se

\footnotetext{
${ }^{22}$ Linhas de fuga são momentos de desestruturação de molaridades, de desenraizamento de estratos para lançar-se em territórios desconhecidos.
} 
fissuraram da identidade. Os cacos de um ser só poderão ser recompostos após se observar atentamente a essas partes que os constituem, assim, algumas se preservarão e outras serão liberadas. Essa ruptura com a identidade - a representação da ausência - é tema central da dramaturgia contemporânea. Em Hilda Hilst, todos as suas figuras são calcadas em suas zonas de incerteza, de turbulência, de crise e questionamentos - funcionando como mote condutor da trajetória dramaturgica.

Nesses momentos de cisão, de fortes mudanças pessoais, retornamos a velha metáfora do espelho - partimos-nos, para depois nos recompor. Esse processo de reconstituição do "eu" se dá assim como a formação de identidade da criança no estágio do espelho ${ }^{23}$ classificado por Lacan. Primeiro ela reage como se a imagem refletida não fosse sua, depois reconhece as partes, para por fim reconhecer esse "outro" como sua própria imagem.

No meu processo de criação existe um momento de "possessão" da figura feminina pelo animal serpente. Nesse momento ocorre uma ruptura do eu especular e do eu corporal do sujeito. O corpo é o "cavalo" - a casa - onde um outro ente habitará, seja humano ou animal. Quinet reflete sobre o fenômeno de possessão em um paciente e cita o $\mathrm{Horla}^{24}$, como um outro vindo de alhures (dos selvagens trópicos), com tal poder que termina tomando sua casa, seu Heim. O estrangeiro tomou-Ihe o que ele tinha de mais familiar. Não só sua casa, mas sua imagem especular tornaram-se objetos do gozo do outro.

\footnotetext{
${ }^{23}$ Lacan introduz aqui o tema do corpo próprio (corps propre). A criança realmente não distingue seu corpo do mundo ambiente. Mas, entre os 16 e 18 meses - a terceira etapa do estádio do espelho - identificando-se a uma imagem que não é ela própria, acaba por se reconhecer, por apreender a forma global ( a gestalt) de seu próprio corpo, como uma imagem exterior de seu próprio corpo. Assim, o sujeito antecipa sua própria maturação. Fages. 1977. p. 25

${ }^{24}$ Quinet. 2002. pg 141.
} 
Em Meshes of Afternoon o espelho aparece em vários contextos e gerando diversas possibilidades de significação. Ele aparece no reflexo da "persona" através da lâmina da faca, no rosto da morte reproduzindo quem lhe olha na face, nos seus estilhaços lançados ao mar.

As possibilidades de significação do espelho na narrativa liminal de Meshes of Afternoon são primordialmente conectadas com a distorção da imagem, da identidade da figura central. O único momento em que ele reflete sem distorcer - em sua inteireza - é no momento da aparição da Morte, em que seu rosto especular reflete a identidade do corpo que espera por um fim.

\section{A faca}

A faca se manifesta como símbolo em vários movimentos "cortantes" da personagem e na narrativa não linear. David Mamet ${ }^{25}$ lança um olhar sobre os usos da faca enquanto símbolo, enquanto a que corta o pão e a que mata. Esse duplo significado da faca permite diversas construções do corpo em cena. Ora a faca é sinuosa feminina ao cortar o pão e ora age incisiva e cruel, como no movimento do bote da cobra, extremamente masculino. Assim, a faca é dual e mimetiza o poder feminino e masculino.

Em Meshes of Afternoon a faca aparece junto ao pão e depois como instrumento de instintos assassinos. Seu simbolismo no filme cria esses dois sentidos paralelos.

A faca tem seu simbolismo, em geral, como outros instrumentos cortantes, como princípio ativo (masculino) que modifica a matéria passiva

\footnotetext{
${ }^{25}$ Mamet, Os Três usos da Faca, 2001
} 
(feminino). Ela é o instrumento essencial dos sacrifícios, das provas iniciáticas e em muitas tradições é associada ao falo.

\section{A morte}

A presença da morte representa uma etapa da investigação do Ritual no Teatro. A morte é a metáfora essencial para essa investigação. Ela é a destruição e a regeneração. Em nossa cultura foi-lhe atribuído um sentido angustiante e sua figuração tem traços assustadores. Resistimos à morte, à mudança e a toda existência de forma desconhecida que ela provoca.

A morte em Meshes of Afternoon aparece como premonição. A figura central se dissolve no caos de seu estágio liminal e a morte surge como a antecipação de um desfecho trágico.

Ela se manifesta com uma flor e invade a casa da "persona feminina", sobe as escadas, deposita a flor sobre a cama e depois desaparece subitamente.

A manifestação da morte enquanto símbolo em Meshes of Afternoon é essencial enquanto " salto qualitativo" ${ }^{26}$ na narrativa lacunar. Sua manifestação é que conduz a persona feminina para a intensificação do estado liminal e desfecho mórbido.

\footnotetext{
${ }^{26}$ Terminologia utilizada por Roberto Alvim, dramaturgo e diretor do Club Noir, para significar uma mudança brusca na situação dada em cena. A instauração de um novo dado dramaturgico que modificará a trajetória corrente.
} 
CAPÍTULO 2

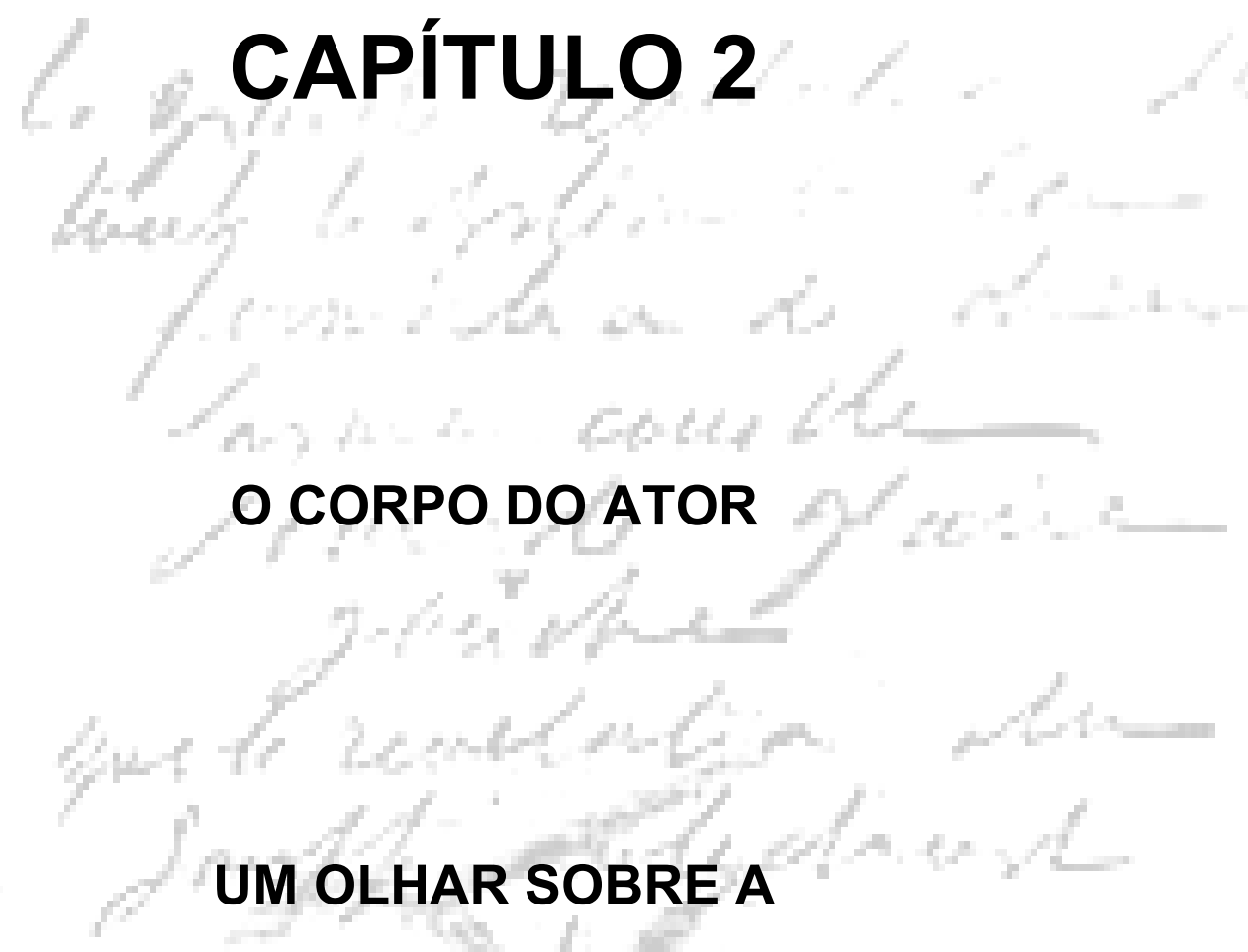

DESPERSONALIZAÇÃO, RITO E MITO NO TEATRO

Capítulo 2 
Nesse capítulo descreverei a contribuição de alguns dos grandes mestres da arte teatral como Antonin Artaud, Jerzy Grotowski e Eugênio Barba na busca de um teatro ritual e na experiência de um corpo múltiplo. A ênfase desse capítulo de forma alguma se dedica a estudar as abordagens ou metodologias desses mestres, ao contrário, o intuito é apenas refletir esses temas, motes de minha investigação, no campo teatral.

Com esse objetivo de lançar um olhar sobre o tema do rito, mito e despersonalização elegi Artaud, Grotowski e Barba como nomes que legaram ao teatro experiências muito interessantes e que se expandiram para outros campos do conhecimento. Artaud nos legou a sua vivência com os Tarahumaras, Grotowski com o Kathakali e o Nô japonês e Barba com o estudo minucioso do candomblé - experiências repercussoras de um novo fazer e pensar o teatro.

$\mathrm{Na}$ investigação do ator como corpo de passagem entre territórios de despersonalização e multiplicidade em seu fazer artístico é que pretendo lançar um olhar sobre rito, mito e despersonalização no teatro. Essa reflexão, portanto, não se aterá a métodos, mesmo porque Artaud não pretendeu sistematizar nenhum, mas em experiências possibilitadoras de rever a arte teatral a partir do contato com outras culturas e tradições mais próximas do sagrado. 


\section{Antonin Artaud}

“O corpo é uma multidão excitada, uma espécie de caixa de fundo falso que nunca mais acaba de revelar o que tem dentro. $\mathrm{E}$ tem dentro toda a realidade.

Querendo isto dizer que cada indivíduo existente é tão grande como a imensidão inteira, e pode ver-se na imensidão inteira." ${ }^{27}$

Esse estudo da despersonalização em Deren pode ser comparada com a idéia do Corpo sem Órgãos e da ação ritual elaborada por Artaud. Apesar de aprofundar uma ampla discussão e uma proposição radical de um corpo liberto, ele não sistematizou um método. Assim, traçaremos alguns paralelos, entre conceitos de corpo estudados por Artaud com o tema da despersonalização e ritual presentes em Deren - fundamentos centrais dessa investigação.

Esse grande pensador surgiu como um grito de revolução em uma época em que a cisão entre o interior do homem e a sociedade começou a se intensificar. Diante dessa realidade ele incitou o fim da ruptura entre pensamento e carne em prol de uma arte que mais do que representar, conseguisse afetar o homem. Keleman em seu livro "O Corpo diz sua Mente" propõe sobre um viés terapêutico a cura desse abismo que Artaud tanto alertou em suas reflexões - a integração da experiência do corpo e mente como um

\footnotetext{
${ }^{27}$ Palestra proferida no evento "Vestígios do Butoh”, em homenagem ao artista Takao Kusuno. Sesc/Consolação, 2/09/2003.
} 
todo.

O CsO (Corpo sem Órgãos) é organismo libertado de seus automatismos, agente do desconhecido, desengrenado da máquina social e conectado com seus próprios apetites.

“ Um corpo assim vivido ultrapassa também os contornos que normalmente atribuímos a um corpo individual. O indivíduo que carrega a imensidão inteira dentro de si não é mais uma entidade destacada do ambiente, uma mônada fechada e indivisível. Ele descobre-se vazado, atravessado pelo infinito de fora, e por isso mesmo pode se ver na imensidão inteira. Um indivíduo que não é mais um indivíduo, mas um lugar, habitado por uma multidão. Multidão de impulsos, sensações, excitações, pensamentos, num movimento veloz e perpétuo de aparição e dissolução. Um corpo-multidão, onde circulam uma miríade de experiências impossíveis de serem completamente catalogadas e fixadas". ( Quilici, 2004. p.198.)

Para investigar essa multidão, esse vazio-fonte de todas as possibilidades de manifestação é necessário criar espaços, ato que implica o esvaziamento de certas representações sedimentadas. Nesse sentido pode-se traçar um paralelo entre a idéia de um $\mathrm{CsO}$ de Artaud e os corpos nômades ${ }^{28}$ classificados por Deleuze, uma vez que eles fogem da fixidez ao construir seus territórios sobre as suas próprias desterritorializações. Assim, a criação é buscada nas linhas de fuga, nas zonas de experiência e do desconhecido.

A proposição do $\mathrm{CsO}$ é o despovoamento de comportamentos viciados

\footnotetext{
${ }^{28}$ É nesse sentido que o nômade não tem pontos, trajetos, nem terra, embora evidentemente ele os tenha. Se o nômade pode ser chamado de o desterritorializado por excelência, é justamente porque a reterritorialização não se faz depois como no migrante, nem em outra coisa, como no sedentário (...) Para o nômade, ao contrário, é a desterritorialização que constituí sua relação com a terra, por isso ele se reterritorializa na própria desterritorialização. ( Deleuze e Gatarri, Capitalismo e Esquizofrênia, pg. 51).
} 
para se encontrar espaço para a verdadeira criação. Construir esse corpo é um ato de revolução interna, que lida com a angústia da morte. É uma reviravolta para se chegar ao humano, no corpo e sua história, afastando-se de qualquer tendência à idealização, como se alicerçam muitas tecnologias atuais. Focault sobre isso afirma: "A liberação das reações automáticas e dos condicionamentos orgânicos fabricados pelo poder é a condição para qualquer revolução". ${ }^{29}$ O corpo é programado e organizado em função de uma ordem social, a que está engrenado. A civilização se alicerça em um projeto de dominação da natureza, os "dispositivos disciplinares" (Focault) se impõem sobre os afetos transformando o homem em um corpo dócil, adaptado e funcional.

O CsO é um corpo nômade por excelência, desterritorializado, que se coloca em constante ato de experiência, de gênese, de descoberta, sem catalogar e mapear a experiência a partir de vivências anteriores, mas simplesmente reconhecer o corpo como zona instável e parcialmente conhecida.

A busca desse corpo nômade é essa busca constante de evolução, de desorganização e reorganização, de ruptura com o lugar-comum, de desautomatização e transcendência. É esse fenômeno de reorganização que se processa no transe das religiões afro-brasileiras por meio da vivência de uma experiência extática que nos reconecta com corporeidades desenraizadoras de nossas molaridades. Para Mário Perniola o ritual é uma

\footnotetext{
${ }^{29}$ Foucault, Vigiar e Punir, 1967.
} 
forma de pensamento do corpo $^{30}$ pautado na desorganização, na angústia, que está ligada a sentir-se deslocado, a não sentir-se em casa. Perniola traz uma importante contribuição ao analisar a religião romana, e perceber o "rito sem mito". ${ }^{31}$ A partir dessa constatação distingue rito de mito, separação segundo ele enraizada na diferença entre milagre e história. "Se o mito remete ao originário, ao arquetípico, ao excepcional, o rito, ao contrário, designa a repetição, a continuidade."

O ritual em sua origem tem essa forte dimensão de trânsito, de mobilização de energias reservadas ou esquecidas. Nesse sentido, podemos relacionar o ritual com o simbolismo da morte e do espelho partido, manifestos em Meshes of Afternoon. A primeira gera a angústia, o caos, que sempre antecedem o luto, o segundo é o próprio símbolo da desestruturação da identidade, do rito - os estilhaços de um espelho são signos essenciais desse fenômeno de desorganização do "eu", de transição.

Esse campo da revolução, da transformação, das zonas de instabilidade, dos processos de transição é o que interessa ligar ao trabalho do artista, pois é desse perder-se que se gera o novo. O intérprete que trabalha a partir de estruturas prontas não cria, pois o conhecido não permite com que se vivencie o verdadeiro ato de gênese - a concepção artística. É no domínio dessa dissolução de imagens congeladas de si mesmo e do mundo que se

\footnotetext{
30 “Pensamento Mítico, pensamento pré-lógico, pensamento simbólico ...com essas e outras expressões semelhantes foi definida a atividade intelectual dos membros das sociedades primárias, em oposição ao pensamento racional, lógico e discursivo das culturas históricas. (...) a expressão pensamento ritual: não se trata de modo algum de comparar o caráter tradicional e estático das sociedades primitivas com o caráter progressivo e inovador da civilização ocidental, mas de apresentar uma mentalidade, uma forma de pensar, uma maneira de se comportar que ultrapassa a distinção entre tradição e inovação, entre sociedade primária e histórica , entre primitivismo e civilização. ( Perniola, 2000. p. 23)

${ }^{31}$ Perniola, 2000. p.19.
} 
calca a metáfora dos espelhos partidos. Nessas zonas de transição que se elaborará meu trabalho - a investigação de territórios desconhecidos. Os repertórios devem sempre se expandir e nunca se estagnar. Para se lançar a um verdadeiro ato de criação é necessário provocar fissuras com camadas estratificadas, lidar com a angústia da morte. A "morte" aqui não se reduz à morte física, mas traduz o desprendimento em relação às formas, visando a não-forma, aproximando-se da experiência do vazio. A morte é inclusa nessa pesquisa como elemento primordial, pois é a experiência do corpo não manifesto - canal de transe entre formas e estados - o "ente" que possibilita todos os movimentos.

Essa figura da morte como experiência ritualística de ruptura de estratos é algo presente na obra de Maya Deren. Em Meshes of Afternoon observamos a morte como o ente desestruturador do cotidiano e provocadora do caos. Essa liminaridade instaurada pela morte é eixo da maior parte dos filmes de Deren. Em alguns filmes aparece de forma implícita e em outros explicita, como no caso de Meshes of Afternoon. A idéia do CsO (Corpo sem Órgãos) como corpo múltiplo e despersonalizado, no intuito de se abrir para diversas possibilidades de experiência, ao invés de se enraizar e se confinar em uma única, é algo comum no pensamento de Deren e Artaud.

Um grande interesse comum entre Artaud e Deren é a dança balinesa. A experiência de Bali para Artaud possibilitou a criação da idéia de um teatro metafísico. Para Deren a experiência de Bali contribuiu para seu projeto pessoal, na sistematização de três formas rituais: os jogos de criança, a performance balinesa e o Vodu haitiano. 
" A revelação do teatro balinês deu-nos a idéia física e não verbal do teatro pela qual o teatro está dentro dos limites de tudo que pode acontecer em cena, independentemente do texto escrito, ao contrário do teatro como concebemos no Ocidente, ligado ao texto e limitado por ele.

No teatro Oriental, de tendência metafísica, oposto ao teatro Ocidental, de tendência psicológica, as formas tomam posse de seus sentidos e suas significações em todos os planos possíveis, ou, se quiserem, suas conseqüências vibratórias não se projetam num só plano, mas sobre todos os planos do espírito, simultaneamente" ( Artaud, 1987, p.56)

O interesse de Artaud por Bali e outras culturas orientais fez com que, hoje, muitos paralelos fossem traçados entre seu teatro e a dança japonesa butoh. $\mathrm{Na}$ década de 60 , ela é afetada profundamente pelas inquietações do criador do teatro da crueldade. Hijikata criou o Ankoku Butoh, cujo radical da palavra Ankoku quer dizer "trevas" e Bu a idéia de evocação. Essa significação remete ao transe, a manifestação de vibrações obscuras, o que permite criar uma relação entre os Tarahumaras, o teatro artaudiano e dança butoh.

Baiocchi expressa na sua descrição da essência do butoh uma idéia que serve em todos os pontos a construção dessa pesquisa de um corpo despersonalizado.

“ Kazuo Ohno explora as faces do ambíguo, fazendo com que os disparates se reconheçam. (...) Suas self-personagens são atemporais e despolarizadas. Sintetizam de uma só vez a criança e o velho, o elemento masculino e o feminino, a treva e a luz, dor e prazer, o feio e o belo, vida e morte. Só através dessa ligação de idéias antípodas é que se torna possível adentrar na pluralidade dos sentidos, exercício do "sair-de-si". O corpo sensorial pode então embrenhar-se 
no oculto e perder a identidade nas múltiplas possibilidades que excitam a própria idéia de loucura. Neutro, ativo, numa fuga de si mesmo, o mais longe do eu narcísico, pois cada salto nômade despersonaliza-se e deixa para trás mais um pedaço de auto-reconhecimento" (Baiocchi, 1995)

Artaud se refere ao seu teatro como ritual. Esse universo do rito é da passagem, da morte, da desestabilização de conceitos e referências para daí se extrair um impulso revitalizante. O sentido do rito vem para romper com comportamentos cotidianos e condicionamentos a fim de atingir uma reorganização pessoal e nos devolver à realidade modificados. Turner classificou como liminal, esse estágio ritual de corpo ainda não manifesto, em zona de passagem.

Artaud fala de uma ação ritual para o artista, no sentido de transcender o tempo cotidiano para criar o tempo da ação poética. É um ato de redescoberta do tempo. Assim, a metafísica da palavra se faz, com esse impulso de transmutação do conhecido. No domínio da poesia é que se instaura a mágica do teatro, a conexão com a experiência do sagrado.

A criação desse tempo ritual será alicerce para o desenvolvimento da minha investigação, pois no tempo poético é possível se reinventar os significados. Nesse momento acontece à mágica do artista em que cria a partir de sua experiência com o sagrado - a sua mitopoética corporal.

\section{Artaud e os Tarahumaras}


Artaud viajou ao México em 1936 para entrar em contato com os índios Tarahumaras, grupo do tronco lingüístico "nahuas", cuja tribo era dos astecas, habitantes das montanhas do noroeste do México. Ele parte obcecado pela idéia de esquecimento de si e pelo processo de desindividualização. Esse povo nômade, provindo da América do Norte, vive da caça e da coleta e possui rituais religiosos nos quais são ingeridas porções da planta Peyotl, chamada por eles de Ciguri. Na dança do peyotl, o rito é executado em círculo. Ali, o delírio da planta jorra para fora do corpo através dos movimentos. Labaredas agitam as sombras dos corpos em transe.

Artaud observou uma série de diferenças dos Tarahumaras em relação a padrões europeus no que se refere ao tratamento e valor que é dado ao corpo.

"Não se trata de uma visão pecaminosa do corpo, que justificaria práticas ascéticas, já que para eles o mal não é o pecado. Para os Tarahumaras, não há pecado: o mal é a perda da consciência Ao invés disso, haveria o cultivo de uma impessoalidade na relação com o organismo: a realidade corporal não é percebida como fundamento de uma identidade. O corpo existe como uma exterioridade descolada da noção de eu." (Quilici, 2004. p.174)

Para os índios Tarahumaras não existe a dualidade do corpo-alma, pois o corpo é um canal de passagem de emoções e estados, sem que eles se fixem, não existindo entre eles o culto de uma subjetividade que se constrói a partir de estados psíquicos geradores de identificação. Ao contrário, os Tarahumaras fazem o "sacrifício de sua consciência" através do Peyotl, deslocando seu sentimento de identidade para restaurar a experiência do corpo. 
O sacrifício dessa consciência traria aquilo que Maya Deren chama de despersonalização, uma vez que os Tarahumaras constroem sua relação com o corpo na base da não identidade a ponto de apagar as marcas distintivas pelas quais figuramos um rosto, região que confere a singularidade ao ser humano. Dessa forma, no rito do Peyotl os sentimentos e estados fluiriam pelo rosto como sobre as águas de um rio, sem se estratificarem, proporcionando assim uma experiência de despersonalização, não condicionada as limitações de um "eu".

Se Ciguri é uma divindade, ela não possui forma ou rosto. Ciguri é apenas uma representação que mascara uma experiência do corpo em êxtase, a celebração da vinda do desconhecido.

Artaud mergulhou nos ritos Tarahumaras e estes contaminaram profundamente sua forma de pensar o teatro, pois revelaram o seu pensamento na desconstrução, no CsO.

A experiência de dissolução da individualidade pelo rito do Peyotl sobre o ponto de vista do corpo é algo que se aproxima do ritual de possessão no candomblé e no Vodu pois é necessário que a pessoa se despoje de suas características para receber uma divindade. O corpo é canal, é passagem, rompendo com sua individualidade e identidade para se permitir vivenciar a elevação ao sagrado. O sagrado nas religiões e sociedades mais primitivas não pode, portanto, ser enquadrada no pensamento ocidental da moralidade religiosa, que aniquila o dual e instaura o maniqueísmo unilateral, responsável pela divisão entre bem e mal.

O rito dos Tarahumaras desejava, portanto, abalar o "eu" em sua raízes 
dissolvendo os limites de uma individualidade.

"Na percepção de Artaud, o ethos primitivo, mais do que um código moral inculcado por uma educação moral, resultaria do cultivo de uma espécie de empatia com a natureza, apoiada na sensibilidade às similaridades e ao destino comum de todos os seres, e numa abertura para fora de si que pode atenuar os limites rígidos do próprio eu. (...) O sacrifício da individualidade enclausurada e a abertura para uma realidade ainda não codificada e não sedimentada passaria por tais distensões preliminares, lapidações necessárias, cultivadas nas situações mais cotidianas." ( Quilici, 2004. p.178)

Artaud descreve em seu livro Les Tarahumaras os vários acontecimentos de sua viagem como etapas de provação e purificação para os cerimoniais do Ciguri. Em Bali Artaud foi um observador, mas nos ritos tarahumaras ele foi um participante, fato que trouxe uma grande repercussão em sua trajetória.

O fato de Artaud ter vivido a experiência do rito do Peyotl - uma planta de poder alucinógeno - faz com que sua descrição não seja sistemática, mas sim poética.

A experiência mexicana de Artaud sobre um ponto de vista antropológico não tenta codificar ou sistematizar elementos rituais para reproduzi-los em outro contexto, pois eles só tem significado dentro do contexto cultural em que eles pertencem. A transposição para uma outra realidade, como a teatral, implica a resignificação.

A aventura de Artaud na tradição dos índios Tarahumaras estimula o interesse antropológico de diversos criadores teatrais por meio de iniciativas 
multiculturais de pesquisa com outras tradições orientais, como é o caso de Grotowski, de Baurrault, como o "Teatro das Nações", Peter Brook e Eugênio Barba com a Antropologia Teatral.

\section{Grotowski - Mito, Transe e teatros orientais}

As experiências multiculturais iniciadas por Artaud com os Tarahumaras influenciaram outros criadores contemporâneos, entre eles podemos destacar Grotowski.

Grotowski em suas pesquisas investigou a preparação dos atores na Ópera de Pequim, no Nô e no Kathakali. A partir dessas experiências ele estrutura um treinamento para se chegar ao que ele denomina de "espiritual". 0 Nô e o Kabuki contém os princípios que regem o uso do corpo vivente em situação de representação. O ator oriental aprende exercícios corporais que são passados de geração para geração, na relação de mestre/discípulo.

No Oriente a arte e a religião ainda estão muito imbricadas e o aprendizado do ator se processa de forma ritualística. O teatro oriental é feito de símbolos de ações e gestos metafóricos que fogem à lógica corporal cotidiana.

"Todos os atores-bailarinos do teatro oriental (Nô, Kabuki, Kyogen, Kathakali, Ópera de Pequim, Odissi e Teatro Balinês), assim como os de técnicas codificadas ocidentais (balé clássico ou mímica Decroux) não partem do princípio da identificação psicológica ou da interpretação de um texto. Eles partem de elementos objetivos que são aprendidos durante 
anos de treinamento. Eles buscam usar o corpo de maneira diferenciada, extra cotidiana, utilizando para isso o que Eugênio Barba chama de 'técnica de aculturação', através da qual o ator busca renegar o natural, impondo-se um outro modo de comportamento cênico. Eles se submetem a um processo de aculturação forçado, imposto de fora, como uma maneira própria de se colocar em pé, de andar, de parar, de olhar, de estar sentado, distinta do cotidiano" (Ferracini, 2001. p. 46)

O contato com o teatro oriental foi determinante na trajetória de Grotowski para a formação do Teatro Laboratório. Essa vivência fez com que se criasse um método de experimentação e não uma "coleção de habilidades", como ele se referia.

"Tudo está concentrado no amadurecimento do ator, que é expresso por uma tensão levada ao extremo, por um completo despojamento, pelo desnudamento do que há de mais íntimo - tudo isso sem o menor traço de egoísmo ou de auto-satisfação. O ator faz uma total doação de si mesmo. Está é uma técnica de 'transe' e de integração de todos os poderes corporais e psíquicos do ator, os quais emergem do mais íntimo do seu ser e do seu instinto, explodindo numa espécie de 'transiluminação'." ( Grotowski, 1987. p. 14)

Grotowski ressalta que seu teatro não educa o ator, mas ensina-lhe a eliminar a resistência ao processo psíquico de transiluminação. Esse caminho de irradicação de bloqueios em prol de um impulso de ação conectada com o interior, ao invés da coleção de técnicas, é o que ele chama de "via negativa". ${ }^{32}$

Grotowski confronta-se com os valores da tradição e percebe o uso do

\footnotetext{
${ }^{32}$ O resultado é a eliminação do lapso de tempo interior e reação exterior. Impulso e ação são concomitantes: o corpo se desvanece, queima, e o espectador assiste a uma série de impulsos visíveis. Grotowski, 1987. p. $14-15$.
} 
mito nos primórdios do teatro, quando ainda era indissociável da religião. Nessa época as pessoas se organizavam como em tribos e incorporavam o mito profanando-o e sacralizando-o. Hoje, o fenômeno catártico de identificação com o mito é inviável em função do declínio da religião.

"A identificação do grupo com o mito - a equação da verdade pessoal, individual, com a verdade universa - é virtualmente impossível em nossos dias.

O que é possível? Primeiro a confrontação, antes que a identificação, com o mito." (Grotowski, 1987. p. 20) (...) a comunidade do teatro não pode, possivelmente, identificar-se com o mito, porque não existe nenhuma fé única. Só um confronto se torna possível. (Grotowski, 1987. p. 96)

Grotowski define a busca de um "ator santo" que retire sua máscara do cotidiano, anulando sua personalidade para penetrar no território do sagrado. Esse fenômeno de sacrifício, de despersonalização que ele compara com a santidade.

"A técnica do ator santo é uma técnica indutiva (isto é, uma técnica de eliminação), enquanto a do ator cortesão é uma técnica dedutiva (isto é, um acúmulo de habilidades)." (Grotowski, 1987. p. 30)

Grotowski busca nesse sacrifício do ator, nessa despersonalização, um "ato total" - um misto entre espontaneidade e disciplina.

No teatro pobre o ator trabalha na criação de uma máscara facial determinada por sua musculatura, cuja expressão permanece ao longo do 
espetáculo, causando uma despersonalização das figuras que passam a ser estereótipos das espécies.

"Enquanto todo o corpo se move de acordo com as circunstâncias, a máscara permanece estática, numa expressão de desespero, sofrimento e indiferença. O ator multiplicase numa espécie de ser híbrido, representando o seu papel polifonicamente. As diferentes partes do seu corpo dão livre cursos aos diferentes reflexos, que são muitas vezes contraditórios..." (Grotowski, 1987. p. 59)

Grotowski, portanto, por meio do seu Teatro Laboratório, verticalizou a experiência de um corpo despersonalizado, múltiplo e confrontador de mitos. Seu legado é fundamental no resgate do fenômeno ritual no teatro.

\title{
Barba e a Antropologia Teatral
}

\author{
Eugênio Barba é fundador do Odin Theatre e a ISTA (Internacional \\ School of Theatre Antropology) - escola sistematizadora da Antropologia \\ Teatral.
}

“Antropologia Teatral é o estudo do comportamento cênico pré-expressivo que está na base dos diferentes gêneros, estilos, papéis e das tradições pessoais ou coletivas.(...) A Antropologia Teatral indica um novo campo de investigação: o estudo do comportamento préexpressivo do ser humano em situação de representação organizada" (Barba, 1994, p. 23 -24) 
Barba ao conhecer diversos princípios de treinamento físico no teatro mundial reconhece o nível pré-expressivo ${ }^{33}$ com "princípios que retornam" presentes no trabalho do ator em diversas culturas que dilatam sua presença e suscitam um corpo em vida.

A descoberta dos princípios que retornam é uma das tarefas da Antropologia Teatral. Nesse contexto observa-se que o corpo cotidiano é condicionado pela cultura, sociedade, entre outras molaridades. Em situação de representação o corpo deve buscar uma técnica extra-cotidiana. Dessa forma, a presença cênica do ator estaria ligada a uma qualidade de ação extracotidiana.

$\mathrm{Na}$ observação de outras tradições teatrais, principalmente orientais Barba classificou como princípios que retornam no corpo extracotidiano o equilíbrio de luxo, a dança das oposições e a equivalência. Não me aterei muito na descrição desses princípios pois o foco dessa investigação é revelar como a experiência desse grande criador do teatro com outras culturas e tradições possibilitou a composição de seu próprio pensamento e técnica de trabalho do ator no teatro.

Barba na formulação da Antropologia Teatral busca distinguir as vibrações da energia do ator em dois pólos: forte (Animus) e suave (Anima) ${ }^{34} \mathrm{~A}$ premissa da sua investigação é definir polaridades que possam ser experienciadas pelo ator. Barba na necessidade de classificar forças

\footnotetext{
${ }^{33}$ A pré expressividade está conectada às técnicas extra cotidianas que geram o “corpo em vida” e dilatam a presença do ator".

34 “Energia Anima (suave) e energia Animus (vigorosa) são termos que não tem nada que ver com a distinção masculina-feminina, nem com os arquétipos de Jung. Referem-se a uma polaridade pertinente a anatomia do teatro...O bayu balinês interpreta literalmente o crescer e o decrescer de uma força que eleva o corpo todo cuja complementaridade Keras/vigoroso e manis/suave reconstrói as variações e matizes da vida.” Barba, 1994, p. 93-96.
} 
arquetípicas para o trabalho do ator estuda Zeami, no tratado de Shikado, e destaca a importância de três figuras: A Mulher (Anima), o Guerreiro (Animus) e o Velho (Anima/Animus).

Essa inclusão do estudo de teatros orientais é algo repercussor nos criadores teatrais contemporâneos. A busca de Barba foi estudar diferentes tradições e culturas para a formulação de um treinamento do ator que fosse universal. Nesse intuito é que estudou profundamente também o candomblé e Vodu haitiano. Adiante segue reflexões sobre esse contato.

\section{Barba e Considerações sobre o Candomblé}

Barba ao analisar o fenômeno da possessão nos transes afro-americanos coloca em discussão o congelamento desse acontecimento em regras estéticas. Ele nos expõe a seguinte questão: "Não será por acaso, porque a crise da possessão modela o homem e seu delírio segundo marcos previstos pela história mítica e como conseqüência ele representa um papel?" A partir dessa questão, ele determina que se a resposta for afirmativa, o transe no teatro surgiria da mimesis e não da convulsão sagrada.

Barba retoma o culto de possessão para verificar a manifestação desses estados de efervescência, que segundo a descrição de Durkheim se encontra a origem de todas as religiões. ${ }^{35}$

O criador da Antropologia Teatral estudou o fenômeno de possessão no

\footnotetext{
${ }^{35}$ Disciplina y Espontaneidad en los trances afroamericanos. Bastide/ Odin Theatre. 1972. p. 104.
} 
candomblé do Brasil e no Vodu do Haiti, assim como Deren. Ele destaca que os cultos de possessão nessas religiões obedecem a uma série de convenções e desconhecem, portanto, o "transe selvagem". Desse modo, a cerimônia do transe é uma socialização que segue as seguintes postulações:

- individual: Barba define o transe quase como uma loucura e sua regulação para que não seja perigoso para as pessoas deve respeitar cerimônias de iniciação, como o bori - dar comida ao Ori - com a finalidade de fortalecer a cabeça e impedir que a manifestação de um ou vários deuses signifiquem uma catástrofe para a saúde mental do filho de santo.

- coletivo: a socialização se efetua por meio da iniciação.

A socialização do transe nas religiões afro-americanas na observação de Barba obedece a um sistema mítico.

"Cada divindade tem um certo rosto e determinada história ... A cerimônia religiosa, desse modo, torna-se mimese e por conseguinte representação de papéis, fato que lhe confere seu caráter teatral." (Bastide ${ }^{36}$. Odin Theatre 1972. p. 108)

Na iniciação existe uma educação da expressão corporal que implica na aprendizagem de danças, gestos e contato com ritmos musicais. Toda religião africana está dirigida, portanto, contra o transe selvagem. Isso torna o transe a mimeses da história dos deuses o que configura alguns transes como mais violentos, porém não selvagens. A fúria de algumas possessões está relacionada com o caráter da divindade, como Ogum e Exu-Legba que possuem uma força

\footnotetext{
${ }^{36}$ Coletânea de Bastide - Disciplina y Espontaneidad en los trances afroamericanos, Odin Theatre. 1972.
} 
masculina mais agressiva.

Barba fez essa interessante observação dos procedimentos que amparam o transe nas religiões afro-americanas para refletir sobre regra e espontaneidade. Rebate a opinião dos psiquiatras que vêem o transe da matriz africana como uma regra que impede a espontaneidade e se transforma em manifestação de histeria coletiva. Ele enfatiza que a repetição não atrapalha a liberdade de jogo e a imaginação criadora e a espontaneidade só se desenvolve com base na tradição dos gestos, das palavras e dos ritmos impostos.

Barba percebe a função lúdica que existe nos cultos de possessão devido a sua organização festiva, que invoca a celebração.

"A possessão é algo demasiado sério. A tomam um tanto, que organizam festas, e como bem observou Durkheim - é o elemento festivo que permite que apareça o lúdico." (Bastide $^{37}$. Odin Theatre 1972. p. 108)

Barba conclui que não existe verdadeira criação, senão dentro da exigência de regras, pois são elas as bases fomentadoras do jogo e da espontaneidade.

${ }^{37}$ Coletânea de Bastide - Disciplina y Espontaneidad en los trances afroamericanos, Odin Theatre. 1972 


\section{CAPÍTULO 3}

\section{O CORPO RELIGIOSO}

$$
41
$$

A DESPERSONALIZAÇÃO, RITO E MITO NO

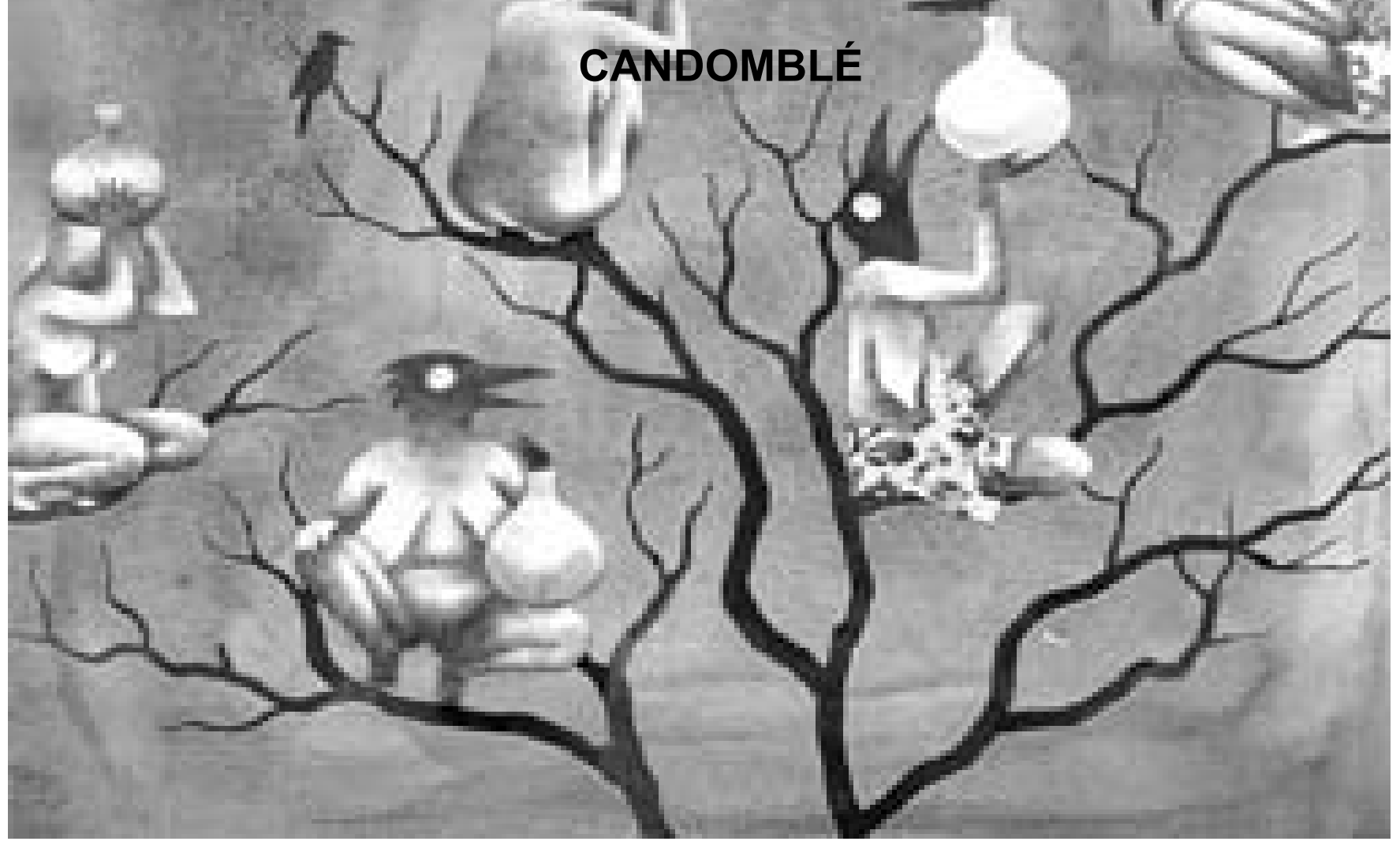




\section{Capítulo 3}

Uma segunda fonte de inspiração desse trabalho será o estudo de alguns arquétipos do candomblé como estímulo na composição cênica.

Nesse capítulo abordar-se-á alguns fundamentos do candomblé em correspondência com conceitos elaborados por Deren para estruturar os motes de interferência dessa tradição religiosa nessa pesquisa: o corpo extático, o corpo múltiplo, a androginia (nos arquétipos elegidos) e o transe.

A análise do fenômeno da possessão será a fonte essencial para o desdobramento de outros fundamentos corporais como a dança em êxtase, a pluralidade de estados e as polaridades entre energia masculina e feminina.

Nesse capítulo explaná-se cautelosamente sobre a escolha de algumas divindades do panteão africano como aparatos da criação da "figura" cênica. Os arquétipos selecionados se encaixam em relações de dualidade, androginia e multiplicidade, fugindo profundamente a qualquer tendência a personalização.

Nesse capítulo, portanto, se estruturará uma análise do corpo religioso do candomblé e suas divindades como matrizes geradoras de um corpo despersonalizado. O "rito com mito" do candomblé remete aos primórdios do teatro enquanto manifestação artística e possibilita uma forma de pensar o "corpo em arte" hoje. 


\section{Considerações do Candomblé à Umbanda}

Uma fonte de inspiração para o estudo do tema "rito com mito" e corpo simbólico será o estudo do candomblé, de seu conteúdo sobre o viés da antropologia: ciência que irá relacionar está manifestação religiosa com as demais na construção de uma identidade mais ampla e não se debruçar simplesmente sobre um estudo etnográfico.

As religiões afro-brasileiras tem sofrido ao longo de sua história muitos preconceitos e julgamentos equivocados, uma vez que são originadas de segmentos sociais marginalizados e explorados. Por elas utilizarem em seus rituais o sacrifício a animais e oferendas as divindades tem sido muitas vezes associadas a "a magia negra". Essa conotação de primitividade foi até afirmada por muitos estudiosos da teria evolucionista, entre eles está Nina Rodrigues. Ele fez uma pesquisa nos terreiros da Bahia e comparando-os com os padrões de evolução da sociedade industrial européia considerou os afro-brasileiros uma sociedade animista e fetichista, que parecia estar muito longe do século XIX.

Assim, a história das religiões afro-brasileiras está intrinsecamente relacionada com o contexto de relações sociais entre negros, brancos e índios. O candomblé, por exemplo tenta preservar até hoje as matrizes religiosas de origem africana e por isso se fala hoje do fenômeno de "empretecimento" do candomblé.

No que se refere a umbanda seu desenvolvimento foi marcado pelo fenômeno de "embraquecimento" das matrizes afro, pois foi uma busca de segmentos brancos da classe média que pudesse agregar a contribuição religiosa 
de outros grupos da sociedade brasileira.

Essa investigação estudará a fisicalidade de orixás primordialmente do candomblé. A pomba gira é uma referência criada pela umbanda no processo de sincretismo brasileiro que está relacionada com as divindades africanas lá Mi. Adiante me aterei melhor sobre essa questão da derivação das lá Mi, mães ancestrais em pomba gira no decorrer do percurso de "embranquecimento" do candomblé.

No candomblé as divindades são compostas só por orixás, que são os santos louvados na raiz africana. $\mathrm{Na}$ umbanda usa-se o termo entidade pois ela integra em seu panteão espíritos de mais luz - de direita - composto pelos orixás e espíritos de mortos, de menos luz - de esquerda - formados por várias linhas. Entre elas estão à linha abaixo dos orixás, a dos caboclos e preto-velhos e a linha dos espíritos das trevas, em menor grau de evolução ainda. A linha dos caboclos e preto-velhos é uma linha intermediária entre os orixás e os espíritos das trevas e é representada por espíritos de índios brasileiros e dos escravos africanos. No caso dos espíritos das trevas estão os exus e as pomba-giras. No catolicismo a figura de exu é associada ao diabo e a pomba-gira a prostituta.

Essa criação da vertente de esquerda que inclui no panteão de divindades da umbanda espíritos de pessoas mortas ocorre em função do sincretismo com o espiritismo. Assim, as pomba giras, exus como Zé Pilintra, Exu Tiriri representam espíritos de desencarnados - eternizados pela umbanda como entidades. Adiante me aterei melhor sobre essa diferença entre o exu do candomblé e o exu de esquerda da umbanda.

É importante também destacar essa diferença entre entidade e divindade. $\mathrm{Na}$ linha da umbanda que integra os espíritos de mortos utilizamos o termo 
entidade, enquanto que no candomblé mais tradicional que mantém a matriz africana só existe o culto a divindades, representadas pela figura dos orixás. Assim, o conceito divindade do candomblé associa seus deuses a mitos, energias arquetípicas, figuras sagradas, se distanciando totalmente ao caráter mais profano e humano de uma entidade da umbanda.

\section{Candomblé - Nações e Variações}

O terreiro de candomblé mais antigo foi fundado no século XIX em Salvador - o llê lá Nassô, conhecido popularmente como Casa Branca do Engenho Velho, de origem iorubá. As dissidências desse terreiro formaram o llê lá Omi Axé lyamase, o popular Gantois e o Axé Opô Afonjá.

O culto na África possuía uma dimensão familiar, exclusivo de um clã ou linhagem. Os templos africanos se restringiam ao culto de apenas uma ou poucas divindades. Os deuses iorubás, por exemplo, eram cultuados principalmente em suas cidades: Xangô em Oyó, Oxossi em Ketu, Oxum em Ipondá e assim por diante.

No Brasil essa estrutura não pode se repetir pois a escravidão separou muitas famílias e etnias trazendo escravos de lugares diferente e portanto com cultos divergentes. Somado a isso, o extremo rigor da perseguição aos cultos africanos no Brasil não permitiu que os templos pudessem dedicar o culto exclusivo a apenas um orixá.

Nesse contexto e devido à catolização dos negros e ao contato cultural com os índios, o culto aos deuses africanos se somou ao dos santos católicos e a divindades indígenas. 
No candomblé a forma de cultuar os deuses foi distinguida pelos negros segundo modelos de rito chamados de nação, pois dessa forma os terreiros tentava reproduzir os padrões africanos de culto e a identidade étnica como nos reinos da África. Nesse processo resultaram os dois modelos de culto mais praticados: o rito jeje-nagô e o angola.

O rito Jejê- nagô abrange as nações nagôs e as jejês. Neles foram preservadas com mais "pureza" as origens africanas.

Nos terreiros onde o rito jejê-nagô é praticado, geralmente se cultuam orixás, voduns, erês (espíritos infantis) e caboclos (espíritos indígenas). Os terreiros onde se privilegiam o culto aos orixás são popularmente conhecidos como candomblé queto; os de culto aos voduns são chamados de candomblé Jejê. Nos terreiros onde se pratica a noção de manutenção da "pureza" ritual do candomblé africano, não existe o culto aos caboclos e sincretismo com santos católicos, sendo mal visto e abolido nesses casos.

Nessas tradições o canto aos orixás é feito primordialmente em dialeto africano, os atabaques são percutidos com pequenas varinhas (aguidavis) e segundos ritmos característicos como o adarrum, agueré, bravum, ijexá, sató e vamunha.

O rito Angola destaca a herança das religiões bantos. Essa nação embora seja mais popular é vista pelo povo de santo como "impura", pois se sincretizou com outras tradições religiosas presentes na cultura brasileira. Os praticantes desse rito possuem um panteão muito mais abrangente. Cultuam, além dos inquices (deuses bantos), os orixás, os voduns, os vunges (espíritos infantis) e os caboclos.

Nos terreiros dessa nação, chamados de candomblé de angola, os 
atabaques são percutidos com as mãos e as cantigas possuem muitos termos em português. Seus ritmos característicos são a cabula, o congo e o barravento ou muzenza.

O candomblé de angola é o rito mais difundido no Brasil pelo grande afluxo que teve de escravos bantos em todo país. Em alguns estados, ele recebeu nomes próprios em função de influências católicas e ameríndias como cabula, no Espírito Santos, macumba, no Rio de Janeiro, e candomblé de caboclo, na Bahia.

Mesmo os terreiros se dividindo por nação, não significa, que pratiquem um culto semelhante a essas mesmas nações na África, pois, como vimos, por maior que seja o intuito de preservação do legado religioso africano, o sincretismo é um fator determinante no candomblé do Brasil, seja em maior ou menor grau.

\section{Umbanda - "Uma Religião a Moda Brasileira" 38}

Nesse sentido, a umbanda, ao absorver o sincretismo que caracteriza o universo religioso afro-brasileiro, interviu nesse campo heterogêneo, com vistas a produzir uma síntese, no nível religioso, das contribuições e contradições dos grupos formadores de nossa experiência social e histórica. É por meio dessas características que a umbanda se afirma como religião genuinamente nacional, uma religião à moda brasileira.

A umbanda, como culto oficializado, teve sua origem por volta das

\footnotetext{
${ }^{38}$ Denominação atribuída por Vagner Gonçalves da Silva em Candomblé e Umbanda - Caminhos da Devoção Brasileira.
} 
décadas de 1920 e 1930, quando os Kardecistas do sudeste e sul passaram a mesclar com suas práticas elementos das tradições religiosas afro-brasileiras, assumir publicamente essa "mistura"com objetivo de legitima-la e atribuir-lhe o status de nova religião.

Embora faltem dados para reconstituir as diferentes linhas derivadas da umbanda, as origens afro-brasileiras da religião retornam ao culto de entidades africanas (orixás e voduns), aos caboclos (espíritos ameríndios), aos santos católicos e a outras entidades marcadas pela influência do Kardecismo.

O Kardecismo foi uma religião trazida ao Brasil por Allan Kardec e muito aceita na classe média. Sua base doutrinária que sustenta a idéia de "guias" (espíritos de mortos) cuja missão é ajudar na evolução do homem. O espiritismo crê na reencarnação e divide os desencarnados entre espíritos "de luz" e "das trevas" $^{39}$. O transe praticado no kardecismo absorve entidades dos cultos afrobrasileiros e codifica a umbanda como religião que irmana todas as raças e classes sociais que formavam o povo brasileiro.

A umbanda, constitui-se, portanto, como uma forma intermediária entre as tradições religiosas de uma classe média e uma classe de excluídos da sociedade. Assim, preservou, por um lado, a concepção Kardecista do carma, da evolução espiritual e da comunicação com os espíritos e, por outro, abriu-se as formas de culto africanos. Contudo, excluiu elementos considerados bárbaros perante a sociedade patriarcal brasileira como: o sacrifício de animais, as danças

\footnotetext{
${ }^{39}$ Os espíritos passariam por sucessivas encarnações ao longo das quais, dotados do livre arbítrio, poderiam evoluir através da prática do bem, ou regredir, cedendo aos vícios do corpo material (promiscuidade, alcoolismo, drogas, etc.) Pela "lei do carma (de inspiração hinduísta), a cada reencarnação na Terra os espíritos colhem os frutos das boas ações praticadas no passado ou pagam pelas más. De acordo com essas ações é que eles se tornam espíritos “de luz”ou “das trevas”. Silva em Candomblé e Umbanda - Caminhos da Devoção Brasileira. Pg. 108.
} 
frenéticas e em alguns casos aboliu o álcool. Nessa re-agregação de valores presentes na formação da umbanda se tornou possível uma maior aceitação da religião entre diversos segmentos da sociedade brasileira.

\section{O transe - a Despersonalização no Rito Religioso. Noção do Sujeito e Corpo no Candomblé}

O candomblé é outra referência importante na construção de corpo do ator em que pauto minha investigação, pois nessa religião ritualística o corpo é despersonalizado funcionando como um elo entre o visível e invisível - meio para manifestação do desconhecido. No momento do transe o humano se diviniza e o divino se humaniza proporcionando a experiência do sagrado.

No candomblé a noção do corpo é extática ${ }^{40}$, ou seja, de corpo em êxtase. Diferentemente da tradição cristã é por meio do corpo que os deuses vêm ao mundo, para celebrar e dançar com os homens. O corpo funciona como um canal para que o "axé" 41 , a energia dos orixás, possa se manifestar. A cerimônia religiosa é um ritual celebrado com oferendas, cantos e danças. Mesmo as oferendas como comidas e perfumes (no caso de orixás femininos) são constituídas de atributos ligados aos prazeres do corpo.

No momento da incorporação o corpo do médium é um "cavalo" ${ }^{42}$ que

\footnotetext{
${ }^{40}$ Corpo em êxtase. Entre a Gira de Fé e Jesus de Nazaré. Silva. p.

${ }^{41}$ Axé; Energia Vital. Força espiritual que reside na natureza (em objetos inanimados como pedras, ou animais e plantas) e representa o poder de realização e a dinâmica das entidades do candomblé. (Silva, Candomblé e Umbanda, Caminhos da Devoção Brasileira, pg. 136).
} 
recebe e se deixa possuir pela entidade. Nesse instante existe uma grande turbulência do corpo, tremores e movimentos bruscos, evidenciando a chegada de uma energia diferente da pessoa que será possuída.

O corpo é um elo entre os dois mundos - o Aiê (humano) e o orum (divino) - manifestando a energia primordial da natureza. Pode-se dizer então que a possessão suprime a distância entre o aiê e o orum, "fazendo com que os orixás encarnem nos homens e transmitam a estes alguma coisa de sua essência divina, ao mesmo tempo em que uma certa dose de humanidade Ihes é insuflada pelos fiéis que concordam em recebe-los" (Goldman, 1987, pg. 111)

Não existe a noção de gênero no candomblé. Dessa forma, uma mulher pode incorporar uma divindade masculina, bem como o inverso também é possível. Não há, sobretudo, a divisão entre o bem e o mal. Todos os orixás contém uma dualidade, conservando atributos divinos, poderes especiais, bem como características essencialmente humanas, como o ciúme, a vaidade demasiada, a ira, a inveja.

“ Os deuses do candomblé são extremamente humanizados, no sentido de que suas emoções e atitudes, narradas nos mitos, são absolutamente inteligíveis e compatíveis com a dos seres humanos (...) Exu é o mais amoral dos orixás, para quem o bem e o mal são contextuais. Várias são as versões dos mitos nas quais é possível perceber que os orixás tem sentimentos humanos. E, que, se são capazes de 'erros', também tem virtudes essenciais." ( Amaral, p. 60 - 61)

\footnotetext{
${ }^{42}$ Cavalo é o termo usado no candomblé e na umbanda para determinar o corpo do médium que funcionará como receptáculo da manifestação das entidades. O corpo é "cavalgado" por uma vibração alheia. (Silva, Entre a Gira de Fé e Jesus de Nazaré, pg. 236).
} 
O ethos do povo de santo é muito diferente do ethos cristão. Os parâmetros do bem e do mal são dados pela mitologia dos orixás e rompem com a idéia de maniqueísmo. O candomblé não rejeita o mundo e nem pretende mudá-lo, ao contrário, ele afirma o mundo, valoriza aquilo que é considerado negativo e demoníaco em outras religiões, como o dinheiro, os prazeres (inclusive os da carne), sucesso e poder.

Na umbanda existe uma divisão, na linha da esquerda ${ }^{43}$, que incorpora até os espíritos de menos luz, como os das pomba-giras e exus, entidades classificadas pelo catolicismo como demoníacas.

Com base nesses preceitos que estruturam o corpo nas religiões afrobrasileiras defino minha investigação na busca de um corpo despersonalizado, estático, andrógino (dupla potência entre o ying e yang) e dual.

O fenômeno da despersonalização, terminologia utilizada por Deren, na designação de um corpo múltiplo, no candomblé é algo fundamental na formação religiosa e no transe.

Essa religião reforça a experiência extática do corpo por meio do ato da possessão, onde o orixá, força divina vêm ao Aiê para dançar com os homens.

Bastide e Lépine defendem que o filho de santo se identifica com a energia do orixá na afirmação de sua identidade e personalidade. Goldmam contrapõe essa idéia, pois define que a identificação já pressupõe dois "eus" que apenas compartilham de características em comum. O orixá é uma força

\footnotetext{
${ }^{43}$. Esquerda é uma subdivisão da umbanda que incorpora espíritos de menos luz como caboclos, marujos, ciganos, pomba-giras, entre outros. (Silva,Entre a gira de Fé e Jesus de Nazaré , pg. 199).
} 
natural composta de uma infinidade de planos ou qualidades e não uma individualidade de qualquer espécie. Assim, o filho de santo no candomblé é pensado como multiplicidade da mesma forma que o orixá. Goldman, propõe a concepção de pessoa e corpo no candomblé como múltiplos. A unidade do eu, é pressuposto da constituição da personalidade nas sociedades ocidentais, onde o desvio desse padrão pode ser visto como uma patologia. Esse entendimento de pessoa e corpo na cultura ocidental é muito diferente do entendimento das religiões afro-brasileiras. Para Goldman:

“...ao contrário do que supõem Bastide e Lépine, acredito ser preciso encarar a noção de pessoa como um sistema mais dinâmico que não só classifica como também visa produzir tipos específicos de pessoas não, certamente, no sentido de gerar 'personalidades' ou 'tipos psicológicos', mas no de uma atualização concreta de certas concepções simbólicas do ser humano e seu lugar no universo."

No candomblé cada orixá também constituí uma multiplicidade, pois eles são subdivididos em qualidades. lansã, por exemplo, possui várias qualidades agrupando uma série de divindades oriundas de diversas cidades africanas. Assim, a lansã que rege os ventos é diferente da que controla os eguns ${ }^{44}$, da que se casou com Ogum. A lansã que se casou com Xangô e também conhecida como deusa dos ventos é a Oyá Petu. Já a lansã que ensinou Oxum Apará a guerrear e era casada com Ogum é a Oyá Onira. Outra lansã é a Oyá Igbalé ou Balé, deusa dos eguns, que os espanta dançando. Dessa forma, percebemos que a atribuição de lansã como mulher que manteve relações com praticamente todos os orixás masculinos é genérica, pois esse arquétipo

\footnotetext{
${ }^{44}$ Espíritos de antepassados mortos, alma ainda não encarnada.
} 
classifica diferentes divindades africanas.

Além da complexidade de qualidades dos Orixás existe a noção de corpo múltiplo, em que a pessoa é formada pelo Ori (cabeça), por sete Orixás conhecidos como "carrego de santo", mais um erêt ${ }^{45}$, um exu e um Egum.

Portanto, a formação religiosa do sujeito no candomblé e a complexidade que abarca seus orixás são configuradas sobre um caráter de despersonalização e multiplicidade.

\section{Os Arquétipos do Candomblé}

Os arquétipos escolhidos surgiram em função da demanda do corpo, que em sua investigação processou estados de androginia, de extrema sexualidade e de dubiedade e por isso foram respectivamente conectados com oxumaré, lá Mi/pomba gira e exu.

A temática da faca, dos espelhos e da morte (elegidos como estímulo a partir do filme Meshes of Afternoon) foram explorados no corpo a partir de alguns exercícios, descritos mais adiante no Capítulo 4. O mesmo tratamento se procedeu com esses orixás, na ampliação de vivências de estados corporais.

Destacarei adiante as qualidades arquetípicas definidoras desses orixás e embasarei suas distinções no candomblé e na umbanda.

\section{Pomba Gira e lá Mi - símbolos da libido}

\footnotetext{
${ }^{45}$ Qualidade infantil do orixá no candomblé. Espíritos de crianças na umbanda.
} 
A pomba gira é uma entidade da umbanda, uma correspondência feminina brasileira do Bombonjira, equivalente de Exu/ Legbáa ${ }^{46}$. A pomba gira é uma entidade de umbanda, nasce do sincretismo brasileiro, não sendo, portanto, cultuada no candomblé.

O termo pomba-gira surgiu de uma "doença de linguagem", resultado de um processo que primeiro transforma o Exu Bombonjira em Bombagira e depois em pomba-gira, recuperando assim palavras que possam fazer sentido em português. A gira na origem bantu é njira que significa rumo, caminho e no português a gira é a roda ritual da umbanda. E " pomba", por sua vez, além de designar ave, designa também os órgãos genitais femininos.

Essa entidade contém um forte caráter sexual e nasce do imaginário popular brasileiro que criou esse arquétipo para incorporar o espírito de mulheres mortas como Maria Padilha, Maria Molambo, Pomba-gira das Sete encruzilhadas, da Calunga, do Cruzeiro, Rosa Caveira, etc.

Segundo Monique Augras as representações das imagens míticas brasileiras explicitamente do poder genital feminino tem sofrido pasteurizações ao serem difundidas numa sociedade mais ampla. Os terreiros tradicionais de candomblé mantêm o culto em toda sua complexidade, enquanto a umbanda parece ter promovido, em torno da figura de lemanjá, um esvaziamento quase total do conteúdo sexual. Essa sublimação ou repressão deu surgimento a uma nova entidade, pura criação brasileira, a Pomba-Gira, síntese dos aspectos mais escandalosos que pode representar a livre expressão da sexualidade feminina aos olhos de uma sociedade ainda dominada por valores patriarcais.

\footnotetext{
${ }^{46}$ Candomblé Tipos psicológicos nas religiões afro-brasileiras. “ De Iá Mi a Pomba-Gira: Transformações e Símbolos da Libido”. Monique Augras. Pg. 31.
} 
Mães, esposas, amantes, as Aiabás $^{47}$, as Rainhas são ancestrais poderosas cultuadas ao lado das lá Mi Oxorongá. Para os iorubás as lá Mi "minha mãe" - eram o símbolo do poder feminino e sexual representado na figura dessas terríveis mães ancestrais. Assim, as lá Mi Oxorongá eram as donas do pássaro da noite, as Awon lá, mães do segredo, andróginas, contém em si todas as oposições, o bem e o mal. São muitos os mitos no candomblé fazem referência à sexualidade das Aiabás, vivida em toda sua plenitude e multiplicidade. A umbanda, porém, castra a sexualidade latente na figura da lemanjá africana e produz o seu contrário: a Pomba-gira, entidade sensual, agressiva, ligada a desordem e muitas vezes associada com a prostituta. No entanto, a umbanda recupera essa figura transgressora, controlando-a, bem como a subversão que ela representa, para reafirmar a ordem vigente e os valores tradicionais da sociedade patriarcal brasileira.

Bastide chamou a atenção também sobre essa tendência de "moralização" que vinha sendo submetida a figura de lemanjá, atribuída no sincretismo como nossa Senhora da Conceição. Essa santificação de lemanjá como "boa mãe, que rejeita aspectos mais explicitamente sexuais não acontece no candomblé tradicional, onde se vivifica essa potência das Mães Ancestrais.

Esse processo da umbanda é explicado em função dessa adaptação as tradições religiosas presentes no Brasil como o catolicismo. Enquanto no candomblé africano a imagem de lemanjá é representada como sereia negra de seios nus, no Brasil ela é uma moça branca, linda, de cabelos compridos, com vestido longo que sai do mar.

\footnotetext{
${ }^{47}$ Termo que designa os orixás femininos
} 


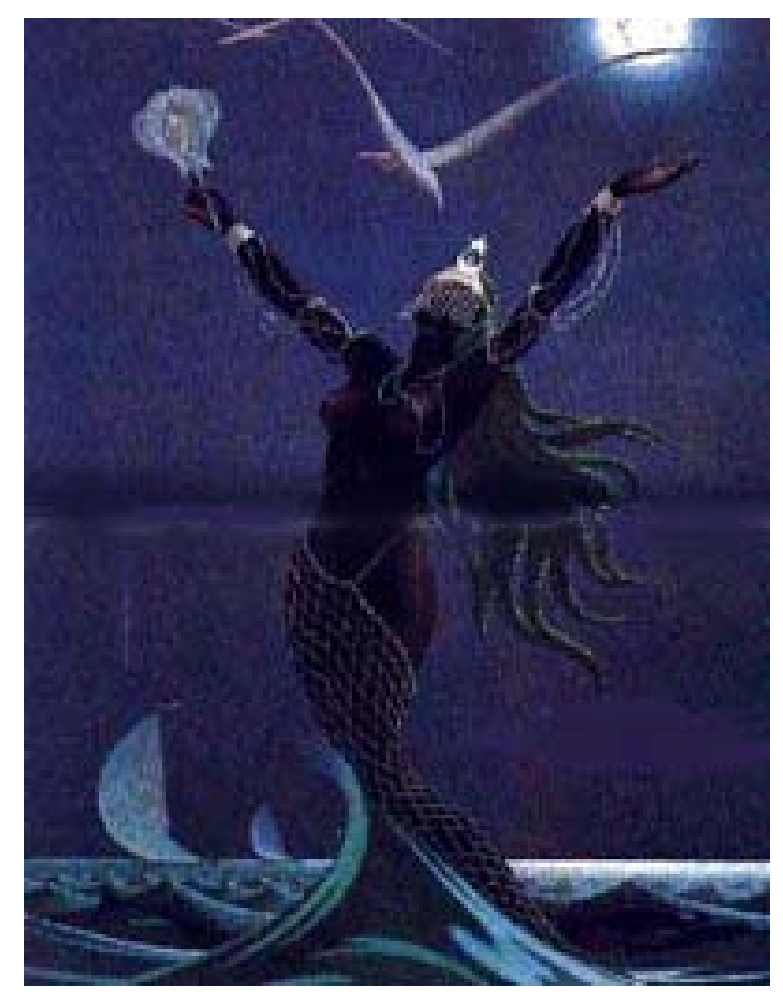

lemanjá do Candomblé

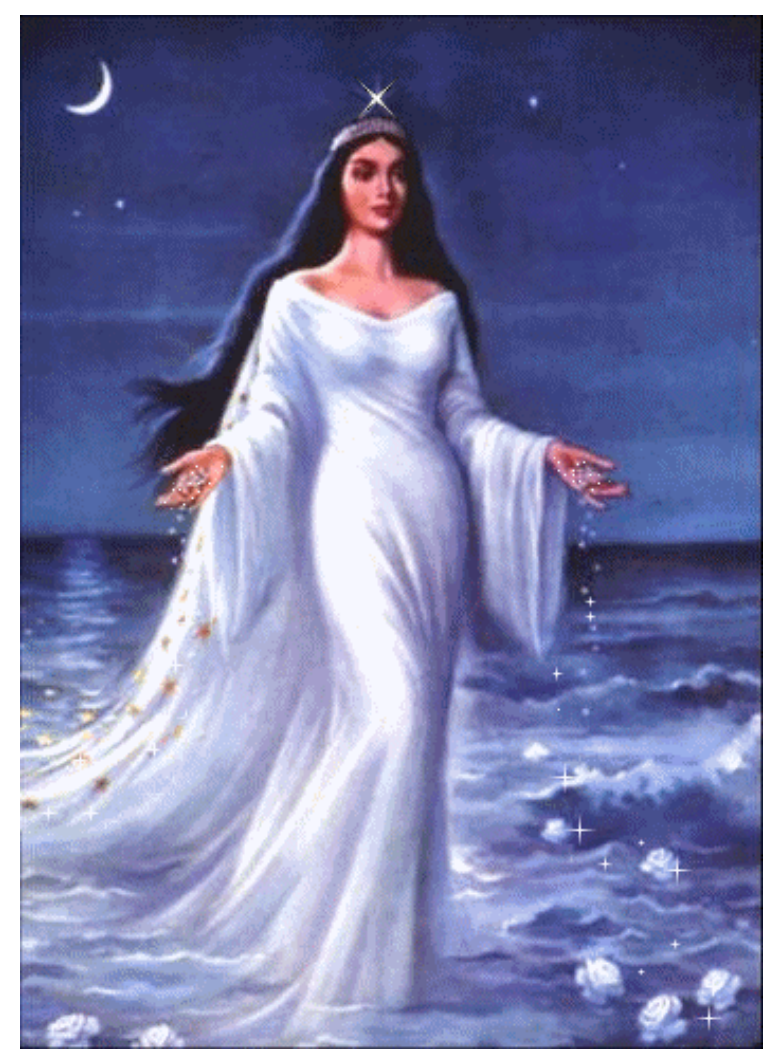

Iemanjá na Umbanda

Nesse confronto entre o candomblé e outras tradições religiosas do Brasil 
é que surgiu o mito da pomba-gira - entidade que começou a ser determinada como o arquétipo classificador de espíritos de mulheres dotadas de erotismo.

Maria Padilha foi inserida no arquétipo das pomba-giras. Ela era uma personagem histórica espanhola, amante de Pedro I, rei de Castela (13501369). D. Pedro abandona D. Blanca de Borbon, poucos dias depois do casamento, para ir atrás de D. Maria de Padilha, de quem estava loucamente enamorado. Estabelece sua corte no Alcázar de Sevilha. Essa transformação de uma figura histórica espanhola em entidade de umbanda está por merecer investigação específica. ${ }^{48}$

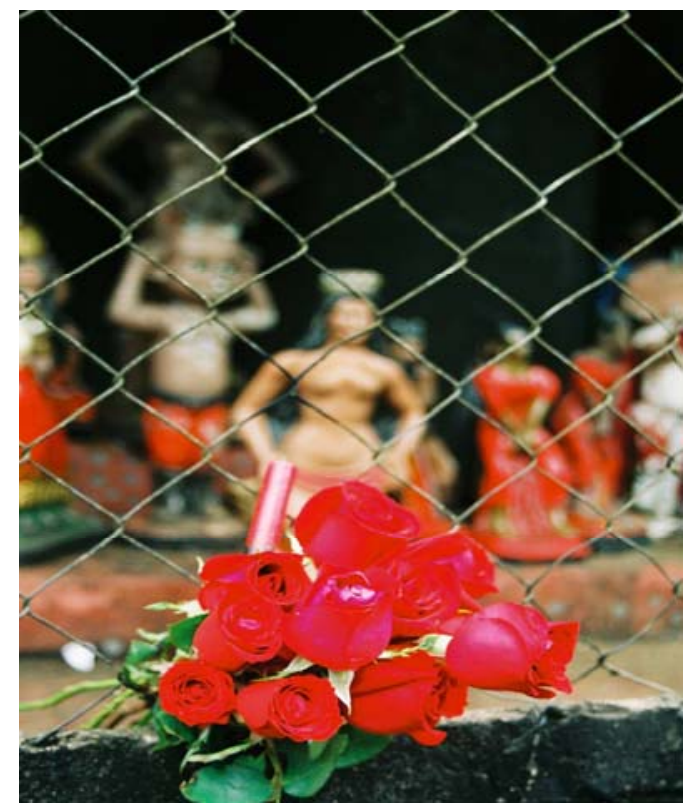

Altar da pomba gira no terreiro de pai Toninho

As pomba-giras são associadas aos prazeres do corpo e portanto sempre bebem bebidas doces, como o licor, fumam cigarrilhas e dão altas gargalhadas. São cultuadas em cemitérios, em encruzilhadas e estão ligadas com os mistérios da morte e a sexualidade do corpo. As pomba-giras são entidades

\footnotetext{
${ }^{48}$ Marlyse Meyer conta a história da transformação de Maria Padilha de amante do rei de Castela a pombagira de umbanda em “Maria Padilha e toda sua Quadrilha” pg. 41.
} 
que por sua vez se dividem em várias falanges. Existem a falange da pombagira das calungas(cemitérios), a das encruzilhadas, a das matas, a das almas.

Meu intuito nesse trabalho é trabalhar com a energia das lá Mi. Utilizo o nome da pomba gira pois é um arquétipo mais difundido no Brasil, mas que remete as mães ancestrais em seu surgimento. Como o foco dessa investigação é a coexistência de diversas potencias em um só corpo, acredito que as lá Mi são um símbolo totalmente pertinente, pois agrupam em seu arquétipo a dualidade entre a "mãe" e a "amante", termos de como se classificariam essa complexidade na estrutura patriarcal de nossa sociedade. Assim, não há nessas poderosas figuras arquetípicas distinção entre a energia de procriação e acasalamento, uma vez que o símbolo da grande vagina, que as representam, é a metáfora do sexo e da maternidade, bem como da feitiçaria. Essas figuras são bastante complexas e adiante me aterei mais detalhadamente sobre elas.

\section{lá Mi (ou lá Mi) - o Poder das Mães Ancestrais}

“As lá Mi Oxorongá são as nossas mães primeiras, raízes primordiais da estirpe humana, são feiticeiras. São velhas mães-feiticeiras as nossas mães ancestrais.

As lá Mi são o princípio de tudo, do bem e do mal.

São vida e morte ao mesmo tempo, são feiticeiras.

São as temidas ajés, mulheres impiedosas. As Oxorongá já viveram tudo o que se tem para viver. As lá Mi conhecem as fórmulas de manipulação da vida, para o bem e para o mal, no começo e no fim. Não se escapa ileso do ódio de lá Mi Oxorongá. 
O poder de seu feitiço é grande, é terrível.

Tão destruidor quanto é construtor e positivo o axé,

que é a força poderosa e benfazeja dos orixás, única arma do homem na luta para fugir de Oxorongá. "

Prandi

Entre os iorubás, o poder feminino é sintetizado por um termo coletivo, Awon lá Wa, "nossas mães". A virtude da maternidade que têm as mulheres é e foi também motivo de temor em muitos povos antigos, algo que era inexplicável, pelo qual as mulheres sempre foram vistas como possuidoras de certo poder especial.

Essas deusas são particularmente homenageadas no festival Geledé realizado entre março e maio, antes do começo das chuvas, entre o povo africano. O objetivo do Geledé é precisamente aplacar as terríveis mães ancestrais para que a fecundidade dos campos se possa processar. As grandes mães, denominadas na forma singular em lá Mi, "minha mãe", na simbologia iorubá são representadas pelo pássaro, com símbolo do poder procriador. Esse poder metaforizado na figura do pássaro permanece impermeável as investidas dos valores patriarcais. É o poder de Ajé, temíveis feiticeiras, aludidas como Eleiye, Dona do Pássaro, pois também formam um coletivo que expressa os poderes da mãe terrível, que se chama lá Mi Oxorongá.

O aspecto cultural que tende a transformar a mulher dotada de grande intuição em "bruxa" é também uma forma de sublimação das sociedades patriarcais dessa força arquetípica das Ajé. Uma das Ajé seriam lá Mi Apaoká, a jaqueira, a verdadeira mãe de Oxóssi. Conforme as tradições africanas "Apaoká a 
árvore ao pé do qual o caçador encontrou mel, e em cujo redor desenvolveu-se a cidade de Ketu, substituída em Salvador pela jaqueira." 49

O poder maternal relacionado a fecundidade por meio do sangue menstrual, que é a marca que pauta a conversão da menina numa mulher, daí em diante será considerada também uma lá $\mathrm{Mi}$, aquela que em qualquer momento deixará de ter a regra, inchando-se o ventre, revelando que tinha em seu interior a "cabaça da existência", o caminho pelo qual todos vêm do Orun $^{50}$ para o Aiê ${ }^{51}$. Para confirmar, porém, a transformação em "mulher", levam-se a cabo os "ritos de passagem" nos que as meninas-mulheres estarão isoladas durante vários dias, alimentadas e vestidas de um modo especial, onde conhecerão todos os segredos relacionados com as mulheres, que serão devidamente dados pelas anciãs de sua comunidade.

Os ritos assegurarão entre outras coisas que seja possuidora de uma "cabaça" fértil e o alinhamento de seu lado espiritual feminino com seu corpo, convertendo-a numa mulher em todo sentido. Há ao final uma apresentação em público das garotas que deixaram atrás a etapa da "meninice", para que os homens Ihes tenham em conta no momento de querer escolher uma esposa.

A palavra lá mi expressa um sentido de reverência àquela que serve de ponte entre os antepassados e os vivos, bem como também reflete seu importante papel maternal. Desse modo todas as divindades femininas são chamadas também lá Mi, não no sentido de "bruxas", mas de mães espirituais.

\footnotetext{
${ }^{49}$ A Jaqueira na África é conhecida como a árvore Apaocá. Lépine, 1978 pg. 32

${ }^{50}$ Orun é o mundo dos deuses.

${ }^{51}$ Aye é o mundo dos mortais.
} 
Quando se fala de lá Mi Oxorongá modifica-se o conceito antes exposto, pois se refere ao mito sobre o poder feminino associado às aves a partir de certas espécies que atacaram a mente do homem. Ainda que também não isolado das mulheres ou dos Orixás o mito das lá Mi se relaciona com o pássaro por seus estômagos, mais precisamente com seu útero, ao qual sempre nos referimos como Igba Iwa (a cabaça da existência). Trata-se da comparação metafórica entre um ovo fecundado e a barriga da mulher grávida, onde se costuma dizer que a mulher tem o "poder do pássaro encerrado na cabaça".

O mito lá Mi Aye então, não é o culto às mulheres feiticeiras nem às aves macabras - mas uma associação metafórica entre o poder feminino da fecundação e o poder místico de algumas aves noturnas, que somado a certos temores e sentimentos negativos dos seres humanos cria no espaço etéreo os Espíritos Coletivos das Eleiye (donas do pássaro) ou lá Mi Ajé (Minha mãe feiticeira).

Estes espíritos podem ter sexo masculino ou feminino e sempre vem em casal, representando o equilíbrio, a dualidade existente em todos os planos. A crença popular iorubá crê que têm forma humana com plumas. 


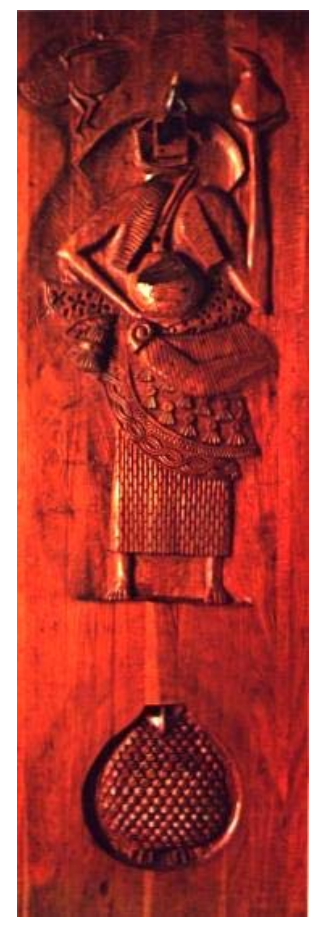

lá Mi Oxorongá - Ilustração Hector Carybé

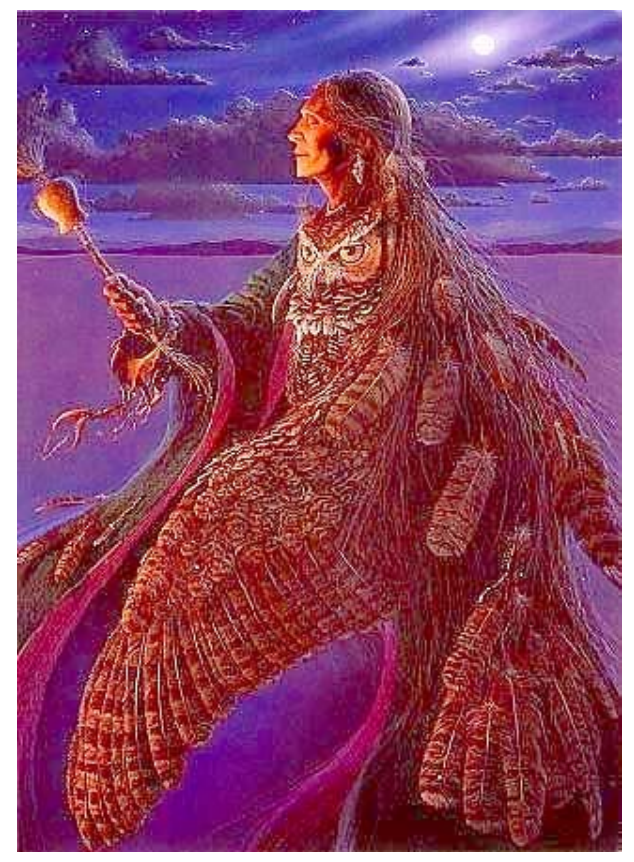

lá Mi

As lá Mi Ajé atuam têm estreita relação com outros Orixás como Ogum - o dono dos sacrifícios e quem provê o sagrado líquido pertencente à Eleiye . 
Crê-se que as lá Mi se reúnem em assembléia numa mesa presidida por Oso, onde se conspiraria e especularia sobre as maldades a se realizar enviando os Ajogun ${ }^{52}$ após o questionamento se foi feito ou não o ebó ${ }^{53}$ marcado por Babalaôs ${ }^{54}$ através de Ifá $^{55}$, deste modo servem de reguladores do comportamento frente às dívidas geradas ante as divindades, por causa de ter rompido o equilíbrio existente de alguma maneira seja numa vida anterior ou na presente.

A lá Mi Aye pertence todo sangue derramado na terra e também são quem controlam o sangue menstrual, o qual quando aparece revela a presença próxima destas criaturas, o que no mito explicaria as dores típicas e o comportamento histérico que costuma ter as mulheres nessa etapa. Isto também é outra razão pela qual nos sacrifícios com sangue não devem tocar a terra - existindo um método ritual que evita isso - e por que a mulheres com sua regra devem manterse afastadas do culto. Ao suceder qualquer das duas coisas ou ambas, seria um tabu e a cerimônia estaria quebrada, devendo conferir ao oráculo por alguma solução.

Presume-se que a palavra Ajé utilizada como "bruxa" prove da contração de lá Ajé (a mãe que come) aludindo a seu voraz apetite, sempre atraída pelo cheiro de sangue e vísceras ela pode vir sob a forma de mosca, pássaro, gracioso ou inclusive outros animais.

\footnotetext{
${ }^{52}$ Egum feiticeiro das Iá Mi Ajé.

${ }^{53}$ Sinônimo de despacho.

${ }^{54}$ Adivinho, praticante dos jogos divinatórios

${ }^{55}$ Oráculo dos deuses africanos
} 


\section{Exu}

Exu é o orixá mensageiro, responsável pela comunicação entre o Orun e Aye, mundo dos deuses e dos homens. É uma das figuras mais polêmicas do candomblé. Desde sua origem na África, está associado ao poder de fertilização e a força de transformação das coisas. Nada se faz, portanto, sem a sua permissão. Entre os objetos que o representam está ogó, instrumento de madeira esculpido em forma de pênis e adornado com cabaças e búzios que representam os testículos e o sêmem.

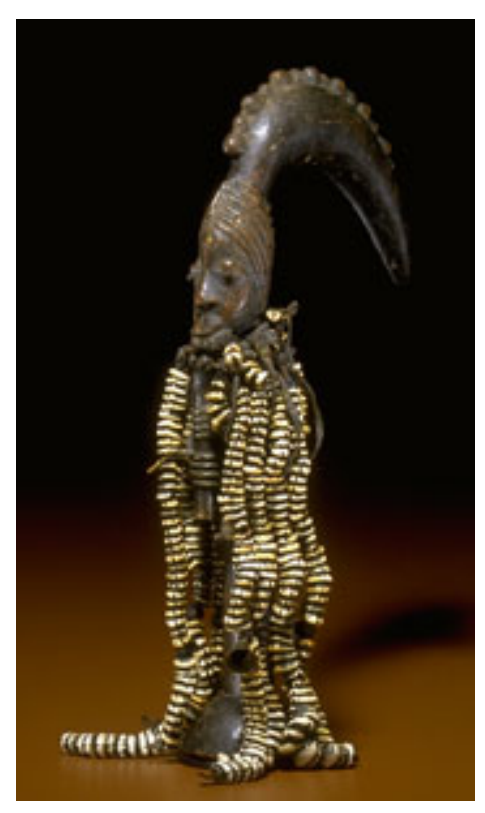

Ogó de Exu na representação do mito africano

No candomblé, como na África, Exu é concebido como divindade múltipla, assim como ocorre com os outros orixás, que são reconhecidos e venerados através de diferentes invocações, qualidades ou avatares, cada qual referido a um aspecto mítico do orixá e a sua função específica no patronato do mundo. Exu, 
nos ritos de candomblé, é sempre o primeiro a ser louvado. É um espírito justo, porém vingativo, nada executa sem obter algo em troca e não esquece de cobrar as promessas feitas a ele.

Na África e no Brasil na época colonial, Exu foi sincretizado erroneamente com o diabo cristão pelos colonizadores, devido a influências católicas, por ter um estilo irreverente, brincalhão e pela forma como é representado no culto africano, com um falo humano ereto, simbolizando a fertilidade.

Exu é considerado o mais humano dos orixás, pois o seu caráter se iguala ao do ser humano em suas ações e atitudes. Assim, Exú é ligado a aspectos sublimados em outras tradições religiosas como os prazeres do corpo, dinheiro e poder. Essa figura demonizada pelo cristianismo é dotada da dualidade bem e mal, sem reprimir os aspectos sexuais e festivos, pois exú gosta de beber cachaça, gosta de sexo e de fazer brincadeiras traiçoeiras na mitologia africana.

As oferendas a Exu são depositadas nas encruzilhadas, os locais de passagem. Exu Elegbara no culto afro é representado por um montículo de terra em forma de homem acocorado, ornado com um falo de tamanho respeitável. Essa metáfora do falo é que confere a Exu seu caráter libidinoso e lascivo.

Os primeiros europeus que tiveram contato na África com o culto do orixá Exu dos iorubás, venerado pelos fons como o vodum Legba ou Elegbara, atribuíram a essa divindade uma dupla identidade: a do deus fálico greco-romano Príapo e a do diabo dos judeus e cristãos. A primeira por causa dos altares, representações materiais e símbolos fálicos do orixá-vodum; a segunda em razão de suas atribuições específicas no panteão dos orixás e voduns e suas qualificações morais narradas pela mitologia, que o mostra como um orixá que 
contraria as regras mais gerais de conduta aceitas socialmente, conquanto não sejam conhecidos mitos de Exu que o identifiquem com o diabo (Prandi, 2001: 3883). Atribuições e caráter que os recém-chegados cristãos não podiam conceber, enxergar sem o viés etnocêntrico e muito menos aceitar. Nas palavras de Pierre Verger, Exu "tem um caráter suscetível, violento, irascível, astucioso, grosseiro, vaidoso, indecente", de modo que "os primeiros missionários, espantados com tal conjunto, assimilaram-no ao Diabo e fizeram dele o símbolo de tudo o que é maldade, perversidade, abjeção e ódio, em oposição à bondade, pureza, elevação e amor de Deus" (Verger, 1999. p. 119).

Transfigurado no diabo, Exu teve que passar por algumas mudanças para se adequar ao contexto cultural brasileiro hegemonicamente católico e patriarcal. Assim, num meio em que as conotações de ordem sexual eram fortemente reprimidas, o lado priápico de Exu foi muito dissimulado e em grande parte esquecido. Suas imagens brasileiras perderam o esplendor fálico do explícito Elegbara, disfarçando-se tanto quanto possível seus símbolos sexuais, pois mesmo sendo transformado em diabo, era então um diabo de cristãos, o que impôs um inegável pudor que Exu não conhecera antes. Em troca ganhou chifres, rabo e até mesmo os pés de bode próprios de demônios antigos e medievais dos católicos.

Exu recebe no culto africano tem diversas qualidades: como Elegbá ou Elegbará, Bará ou Ibará, Alaketu, Agbô, Odara, Akessan, Lalu, ljelu, Ibarabo, Yangi, Baraketu, Lonan, lan.

Não devemos confundir esse exu orixá africano com os exus que constituem o panteão de divindades brasileiras como Exu Tata Caveira, Tiriri, sete porteiras, 
Mangueira, Capa preta, Corcunda etc. Na Umbanda esses Exus não são como os deuses míticos do candomblé, mas sim espíritos de mortos, entidades que buscam, através da caridade, a evolução. Assim, são executores da Lei Kármica do espíritismo.

Criou-se, com isso, um grande jogo de contradições e a umbanda acabou por se situar num terreno ético que Lísias Nogueira Negrão chamou muito apropriadamente de "entre a cruz e a encruzilhada" (Negrão, 1998). Seguindo o modelo católico, no qual se espelhava, a umbanda foi obrigada a ter em conta os dois lados: o do bem e o do mal. Incorporou a noção católica de mal, mas não se dispôs a combatê-lo necessariamente, nunca se cristianizou completamente. Formalmente, a umbanda criou, desde o momento de sua formação, uma espécie de segunda personalidade, uma separação, um universo paralelo, a " linha de esquerda", dos marginalizados, dos renegados, dos espíritos menos evoluídos, de "menos luz" compostos pelos exus e pomba-giras.

No processo de "abrasileiramento" do Exu africano a umbanda se submeteu a moralização imposta pelos valores católicos e a idéia de lei Kármica do espiritismo para que os deuses míticos do candomblé fossem aceitos pela sociedade patriarcal brasileira.

Gostaria de destacar, portanto, que como o objetivo dessa pesquisa é trabalhar com a dimensão mítica de uma forma mais "pura", ou seja, sem agregar valores culturais que sublimem a potencialidade mítica é que focarei minha investigação na figura do Exú africano, onde sua dualidade e complexidade é mais integrada. Sem contar que na Africa ele é cultuado como mito e força da natureza, 
divergindo de sua configuração brasileira que representa espíritos de homens mortos marginalizados na sociedade brasileira.

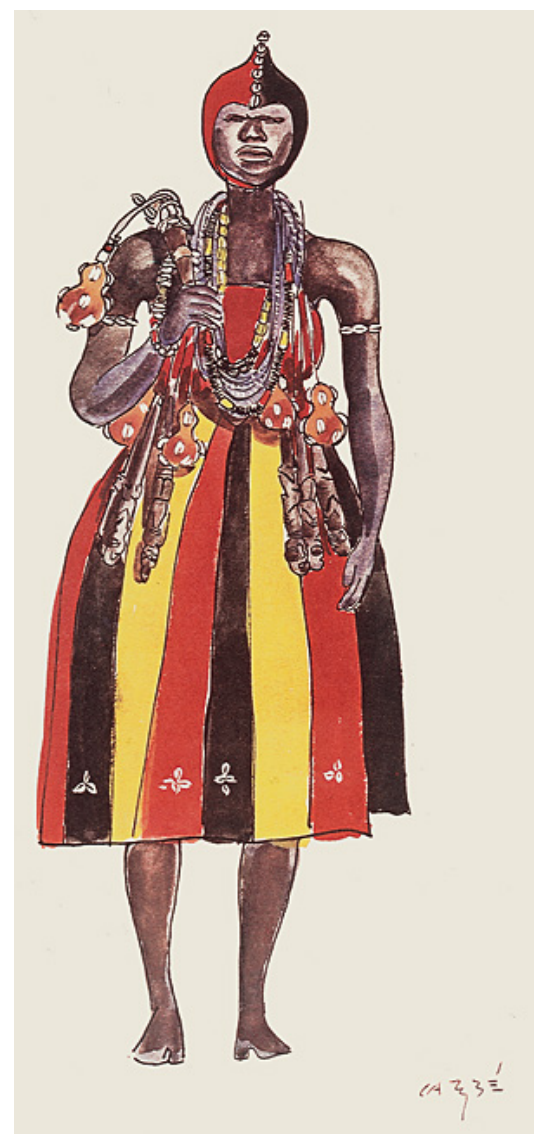

Ilustração de Exu africano de Hector Carybé

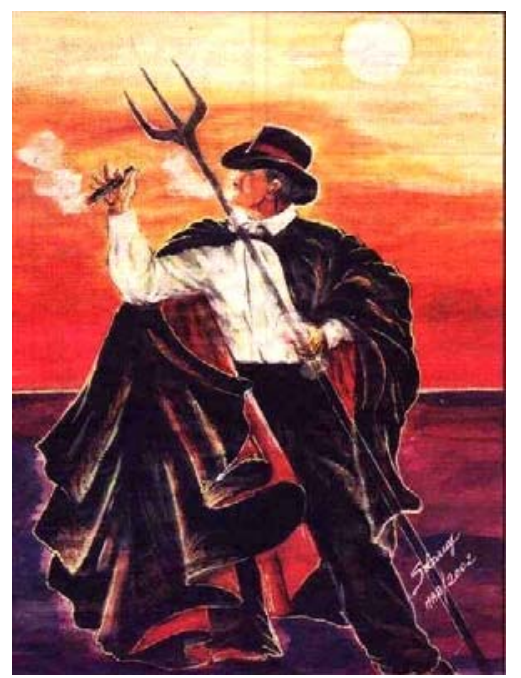

Ilustração do Exu Capa Preta da umbanda 


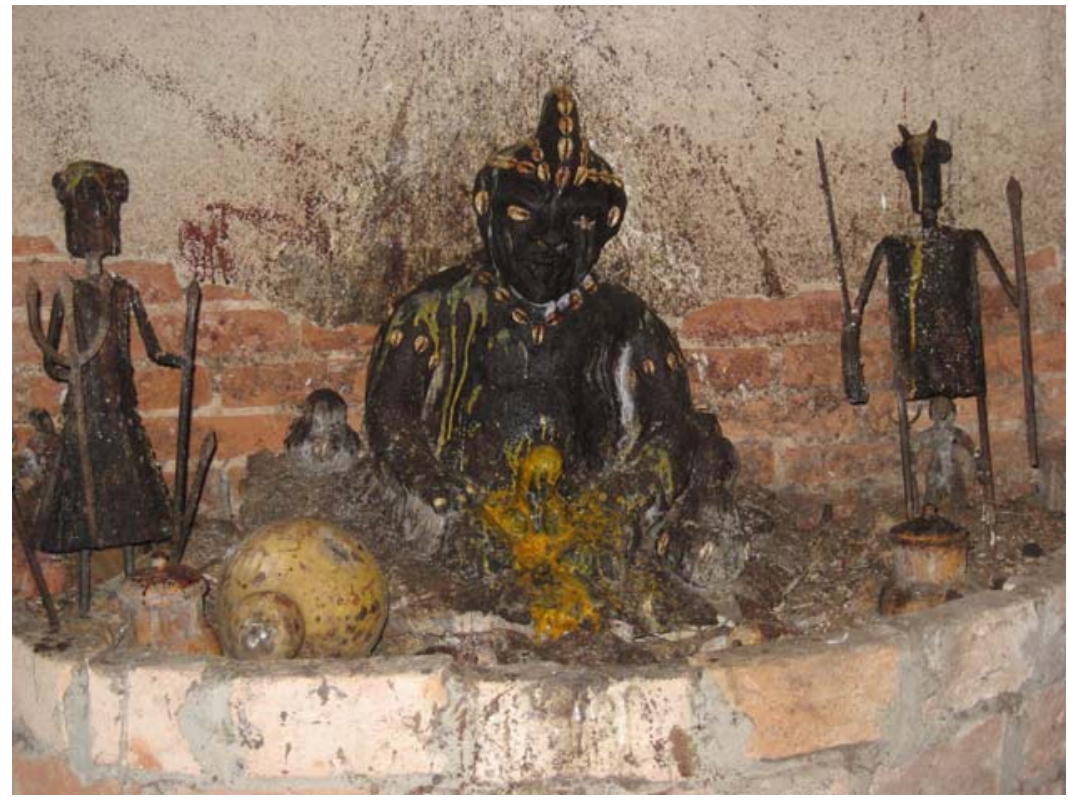

Casinha de Exu - terreiro de mãe Vanda

\section{Oxumaré - a Dualidade da Cobra}

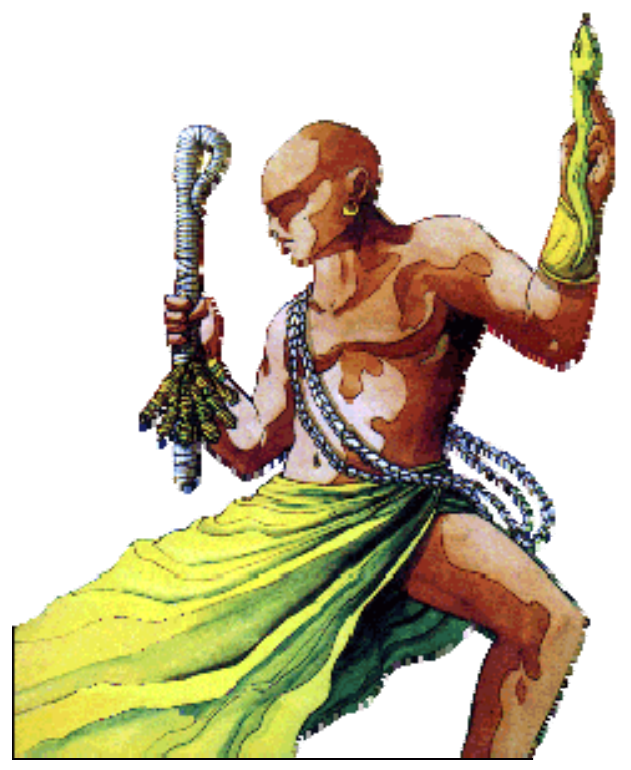

Oxumaré é orixá metá-metá ${ }^{56}$ do panteão africano, pois é durante seis meses metade homem e nos outros seis meses metade mulher. No entanto,

\footnotetext{
${ }^{56}$ É necessário ressaltar que a classificação metá-metá dado ao orixá Oxumaré fica restrita ao plano mítico. Esse, orixá na prática dos terreiros de candomblé, são ditos também aborôs (orixás masculinos). Assim, seu aspecto masculino prevalece, sendo reverenciados na sequência do candomblé, em cerimônias como o Xirê, junto aos orixás aborôs.
} 
quando cultuado prevalece enquanto sexo da divindade seu lado masculino, sendo assim cultuado como aborô. ${ }^{57}$ Os símbolos de oxumaré são o arco-íris e a serpente - animal tão dual quanto o próprio orixá. Adiante falaremos mais sobre o simbolismo da serpente e cobra.

A dualidade é portanto um conceito básico nos mitos desse arquétipo. A ambigüidade de Oxumaré carrega todos os opostos e todos os antônimos básicos dentro de si: bem e mal, dia e noite, macho e fêmea.

Como orixá da Terra, representa as riquezas escondidas no subsolo, mas também desempenha a função de levar a água de volta para o castelo de Xangô, no céu, a fim de garantir a perpetuação do ciclo das águas no planeta. O mito diz que na fase masculina de Oxumaré o arco-íris funciona como a ponte que permite com que as águas de Oxum cheguem ao palácio de Xangô.

Nos seis meses em que o Orixá assume forma feminina ele se torna uma cobra e representa o oposto da fase anterior. Enquanto cobra ele se arrasta agilmente tanto na terra como na água, deixando as alturas para viver sempre junto ao chão, perdendo em transcendência e ganhando em materialismo. Sob essa forma, segundo alguns mitos, Oxumaré encarna sua figura mais negativa, provocando tudo que é mau e perigoso, pois a cobra é traiçoeira, representando a própria dualidade entre bem e mal. A cobra em muitas mitologias é o símbolo da tentação, da transgressão, da provocação e da lascívia.

Oxumaré sobre a forma de serpente é perigoso, mas sobre a forma de arcoíris é pacífico e extremamente belo.

\footnotetext{
${ }^{57}$ No culto as divindades são divididas em aborôs (masculinas), iabás (femininas) e metá-metá (masculino/feminino).
} 
Para os sacerdotes do Ifá, Oxumaré é o mensageiro de Olodumaré, representando o pacto entre os deuses e os homens. Isso lembra a passagem bíblica em que, após o dilúvio, Deus fez um arco-íris aparecer no céu para expressar sua promessa de que o mundo não seria destruído pelas águas uma segunda vez.

Oxumarê é o Orixá do movimento, da ação, da eterna transformação, do contínuo oscilar entre um caminho e outro que norteia a vida humana. É o Orixá da tese e da antítese. Por isso, seu domínio se estende a todos os ciclos regulares, que não podem parar, como a alternância entre chuva e bom tempo, dia e noite, positivo e negativo, em seu movimento de androginia e dualidade intermitente.

\section{A serpente}

Em muitas culturas a serpente é ícone da libido e da fecundidade. No tantrismo ${ }^{58}$, ela é a Kundalini, enroscada na base da coluna vertebral, quando desperta ela opera a ascensão sucessiva dos chacras: a subida da libido, a manifestação renovada da vida. A serpente é ao mesmo tempo signo do masculino, em seu bote, e do feminino ao enroscar-se, beijar, engolir e digerir. Ela é extremamente sensual e imprevisível. Suas decisões são tão súbitas quanto suas metamorfoses, metaforizando assim o ciclo de morte e vida.

A serpente em seu simbolismo, com referência no estudo de Chevalier é a representação da dualidade, da sexualidade profunda, do veneno, do ciclo da morte e da vida, do poder de regeneração e destruição.

\footnotetext{
${ }^{58}$ No tantrismo quando desperta a serpente ( Kundalini) sibila e enrijece, espera-se então a ascensão, a subida dos chacras: é a subida da libido, a manifestação renovada da vida. Chevalier, Dicionário de Símbolos pg. 815.
} 


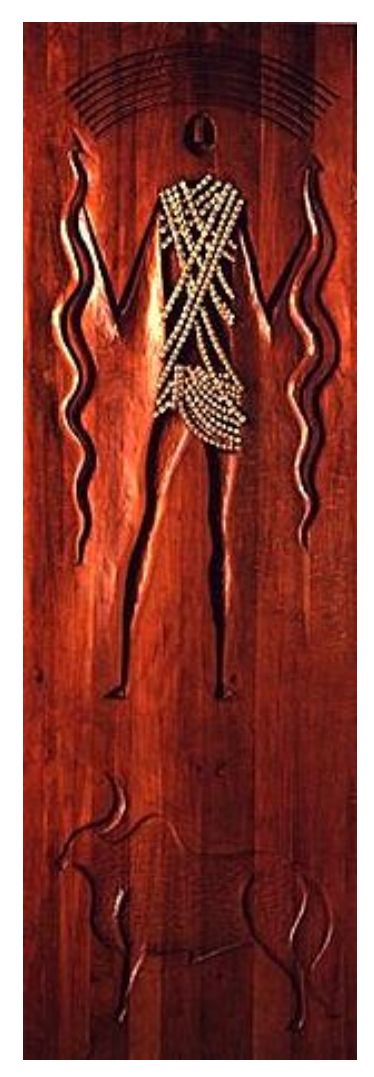

Oxumaré - Ilustração de Hector Carybé

\section{A escolha dos Arquétipos}

A preferência na escolha dos arquétipos do candomblé das lá Mi, Exu e Oxumaré, ao invés de experienciar todo o panteão de divindades compostos por 16 orixás se deve ao fato desses estarem mais próximos dos conceitos corporais que me interessam investigar: a despersonalização, a androginia, a dualidade e a liminaridade.

Essas três forças arquetípicas são complexas demais e como vimos em 
um estudo isolado de cada uma delas, percebe-se uma dificuldade de definilas, de conformá-las ou, como poderíamos dizer, personificá-las, pois elas abarcam diversas características contraditórias em sua expressão. Essa ambigüidade presente nessas três figuras do panteão africano são o material que confere essa capacidade de sair das limitações e confinamentos de uma personalidade. Essa multiplicidade gritante nessas divindades ancestrais possibilita que eles se situem em zonas de passagem, em um caos, uma desordem fértil que é o cerne da fase liminal de um processo ritual.

No próximo capítulo, descreverei com detalhamento como foram explorados corporalmente esses arquétipos como potencializadores de um corpo múltiplo e despersonalizado. Destrincharei o processo de criação e treinamento a partir desses motes poéticos - os possibilitadores de um corpo e dramaturgia comunicante. 


\section{Capítulo 4}

\section{A composição do Espetáculo}

“Eu sinto dor e todos os dias recebo vários golpes!

Golpeio-me! Atiro golpes.

Existir com esse meu contorno é ferir-se, agredir múltiplas

formas dentro de mim mesmo, é não dar sossego as várias caras que irrompem em mim de manhã à noite!"

Hilda Hilst

Fluxo Floema 


\section{Capítulo 4}

\section{A Composição do Espetáculo}

Nesse capítulo propomos discorrer sobre as interferências dos conceitos, símbolos e arquétipos investigados nos capítulos 1 e 3 no trabalho de criação artística. Quais foram os procedimentos técnicos utilizados para a composição do material cênico e de que forma se processou a organização da narrativa espetacular.

Destrincharemos, portanto, alguns exercícios gerados para buscar a despersonalização e a presença do mito (símbolos e arquétipos) no corpo do ator. Por fim, destacamos a importância do Anagrama de Deren e de uma mitologia do candomblé na estruturação da dramaturgia. 


\subsection{Procedimentos técnicos e metodológicos. Instrumentos de}

\section{Pesquisa}

“Transforme a sua patologia em uma mitologia”

Tiche Vianna

Essa investigação na prática se debruçará no estudo de alguns conceitos aprofundados nas referências teóricas. O treinamento corporal, desse modo, se constituiu e resultou na composição do espetáculo, sendo guiado sempre pelos seguintes princípios:

- corpo despersonalizado/ múltiplo de potencialidades;

- corpo como canal de representação do mito ou de energias arquetípicas;

- utilização do mito e símbolos como suportes da confecção dramaturgica;

Essa dimensão mítica só é estabelecida quando se trabalha na complexidade do arquétipo, ou seja, na co-existência simultânea e ambivalente de potências distintas. Para acionar essa complexidade mítica elegemos nessa investigação o trabalho com figuras multifacetadas como as lá Mi, em contraponto 
com a figura mais personalizada da pomba gira, que ganha um caráter mais unilateral - a mulher definida unicamente do ponto de vista de sua força erótica.

Nesse contexto, investigaremos corporalmente os movimentos dos seguintes arquétipos do candomblé, como potencialidades físicas multifacetadas, duais e ambíguas de significações. São as seguintes figuras míticas africanas:

- lá Mi;

- Exu;

- Oxumaré;

Dentro do contexto que envolve o filme "Meshes of Afternoon" como estímulo e fonte de inspiração desse trabalho escolhi três símbolos do mesmo como motes de investigação corporal e dramaturgica.

\section{- A Faca;}

\section{- O Espelho;}

\section{- A morte;}

Adiante descreverei com mais detalhamento os procedimentos corporais utilizados na investigação desses arquétipos e símbolos. Ressalto que esse estudo não segue uma única metodologia na realização do treinamento corporal. Os exercícios e procedimentos foram reformulados e constituídos especificamente para o trabalho de exploração de "estados corporais" motivados por matrizes míticas. Podemos destacar a influência de algumas abordagens corporais como a 
coreologia de Laban e princípios da coordenação motora de Beziérs. Posso falar de interferências e influências de algumas técnicas corporais na formulação dos exercícios, mas afirmo que esse trabalho construiu seus próprios caminhos para a elaboração de um treinamento de investigação de "estados corporais míticos". Assim, não posso falar que criei um método. Não se trata de uma investigação de uma metodologia, mas sim da elaboração de um treinamento físico que sirva o trabalho do ator a partir de sua escolhas temáticas. Nesse caso, os procedimentos técnicos utilizados viabilizaram o trabalho com diferentes qualidades corpóreas para a potencialização de um corpo múltiplo.

O treinamento físico, dessa maneira, se alicerça em princípios gerados dos seguintes trabalhos: de exploração do movimento a partir da sensibilização via toque de Madame Beziérs, princípios de um estudo de desaceleração e improvisações derivadas do trabalho com qualidades corporais esquematizadas por Laban.

\section{Laban}

$\mathrm{Na}$ exploração das corporeidades a partir dos símbolos e arquétipos utilizo a coreologia ${ }^{59}$ de Rudolf Laban como forma de abordagem corporal. A coreologia é um estudo de análise do movimento. Laban não sistematizou um método, pois seu objetivo era justamente permitir ao interprete experimentar todas as dinâmicas e formas de organização do movimento possíveis, para

\footnotetext{
${ }^{59}$.Laban formulou a coreologia - uma abordagem de observação e análise do movimento que ele determinou "lógica, ciência da dança".
} 
ampliar suas possibilidades de criação, ao invés de formatar ou padronizar o corpo. Assim, a coreologia contribui para esse processo no sentido de mapear as fisicalidades estudadas e traduzi-las em "temas de movimento" para que o interprete - criador possa experimentar em seu corpo a qualidade mapeada e gerar outros significados a partir da mesma.

A referência de Laban permitiu com que eu intitulasse meus próprios "verbos" de movimento na exploração de algumas qualidades corporais. Dessa forma, um verbo de movimento que Laban classificaria como "talhar" (pesado, rápido e sinuoso) eu nomeei em meu treinamento, com referência ao símbolo da serpente, de "dar o bote".

\section{Madame Beziérs}

"De quantas personalidades ínfimas é a personalidade humana reunião e produto? Ela é, por sua vez, alguma coisa além de uma célula numa outra personalidade mais vasta, cuja a consciência nos escapa, como a consciência do conjunto humano escapa, na verdade, as células que os compõem?"60

Essa é a questão posta na abertura do livro de Beziérs, sobre essa infinidade de formações que um corpo pode constituir. Madame Beziérs é uma fisioterapeuta que investigou profundamente o "percurso do movimento" (desde sua previsão genética) e os "movimentos fundamentais" para que o aparelho locomotor fosse experienciado como órgão processador de experiência.

O movimento fundamental, seria para Beziérs, um movimento base da anatomia humana que independe de organizações pessoais e finalidades.

\footnotetext{
${ }^{60}$ Beziérs. p. 7 Alexandra David Neel. Apresentação da edição brasileira por Ivaldo Bertazzo
} 
Partindo de alguns movimentos fundamentais de enrolamentos, torções e organizações em forma de infinito $(\infty)$ foram explorados algumas formas de movimentação no treinamento físico.

Abaixo segue um resumo dos estados trabalhados a partir dos respectivos motes e que abordarei a seguir com mais detalhamento:

- lá Mi : exercícios de desaceleração para criar um estado hipnótico;

- Exu: Trabalho com energia animalesca, exercícios de sustentação em quatro patas e outros apoios;

- Oxumaré: exercício a partir de qualidades como rastejar, dar o bote, envolver, digerir, hipnotizar, trabalho com movimentos súbitos e quedas;

- Faca: Exercícios de Expansão e contração Súbitas. Qualidade Trabalhada: Movimentos bruscos e pesados;

- Espelho: 1) Inteiro - Exercícios de Silêncio, pausas sustentadas, relacionadas com estado de contemplação; 2) Partido - Exercícios de fragmentação do corpo em partes, relacionada com a idéia de estilhaçamento da imagem;

- Morte: Exercícios de Quedas e colapsos - espasmos abruptos;

Esse é uma síntese das qualidades suscitadas a partir dessas energias arquetípicas e símbolos como matrizes geradoras de estados. 
Essas qualidades de movimento geradoras dos estados foram escolhidas após longas observações dos arquétipos e vivências a partir dos símbolos como energias potenciais de vida.

\title{
4.2 Descrição dos procedimentos utilizados
}

A escolha dos símbolos que permearão a investigação prática. Os universos temáticos dos símbolos inspirados em Meshes of Afternoon

\author{
A faca \\ Em Meshes of Afternoon a faca aparece em um contexto de instrumento \\ de aniquilação da vida, em outro momento é relacionada ao corte do pão e por \\ fim, se transforma na metáfora do falo - modificador da matéria passiva em \\ ativa. \\ Enquanto universo temático pretendo trabalhar com a faca na metáfora \\ do instrumento de morte e do falo.
}

\section{Espelhos Partidos}

Os espelhos são essenciais na construção da dramaturgia desse espetáculo, em que a "figura feminina" encontra-se em uma zona liminal.

Os espelhos inteiros e partidos constituirão essa oscilação entre identificação e despersonalização na trajetória cuja a "persona" do espetáculo 
perpassa.

\section{Morte}

A iminência da morte é um tema de Meshes que pretendo investigar nesse trabalho. A metáfora da morte está profundamente conectada com o espelho em Meshes, provocando uma profunda intersecção entre a face refletida desse "ente" com o ambiente que ele circunda.

A "morte simbólica" é algo presente em todos os ritos de passagem, onde se abandona uma configuração antiga para se situar em uma nova. Essa idéia de fim, de desestruturação do "eu", esse "corpo que não se agüenta mais" e está a espera da morte é o mote desse símbolo que elegi para a construção da narrativa cênica.

\section{Exploração corporal dos símbolos estudados}

Nessa etapa eu faço uma análise coreológica, com referência em Laban, das qualidades de movimento presentes nesses símbolos a serem trabalhados. A coreologia é um estudo da análise do movimento, capaz de denominar a dinâmica que o compõe por meio de seus vetores: tempo, espaço, peso e fluência. Por exemplo, a faca possui ao ser cortante um movimento direto, pesado e rápido - dinâmica que Laban classifica como "socar", ora direta, leve e lenta - ao cortar o pão, que Laban chama de "deslizar". Assim, ao perceber qual dinâmica constitui o movimento, podemos começar a explorar uma qualidade especifica e elaborar algumas matrizes corporais. Essas matrizes 
são células de vida que contém uma imagem, uma idéia ou mesmo uma ação capaz de traduzir signos.

Com o simbolismo da faca explorei os seguintes verbos: socar, talhar e deslizar. O desdobramento desses verbos de ação no corpo criaram outras células de movimento e estados espasmáticos.

\section{Exercício da faca}

Um outro exercício foi a improvisação a partir do contato com o objeto em si. A relação do corpo com a faca resultou em "estados de espreita". Seria correspondente ao estado de prontidão do animal quando se sente ameaçado, e, em virtude disso, aguça todos os seus sentidos.

No espelho - como signo de contemplação narcísica - explorei o feminino através da circularidade de giros em diferentes partes do corpo, a relação crânio-sacral e o verbo de movimento de Laban "sacudir".

Essas qualidades da circularidade e do "sacudir" foram exploradas em diversas partes do corpo e muitas vezes trabalhadas em movimentos periféricos. Laban cita como movimento periférico a todo aquele que isola uma parte do corpo do seu centro. Ex: movimento só da cabeça ou só da mão como se uma câmera de cinema fizesse um plano detalhe da mão e só a mão entrasse em evidência. Utilizo a ênfase em algumas partes do corpo para criar uma dramaturgia física que traduza os símbolos. Em um momento tem uma cena em que faço movimentos circulares só com a cabeça e em outra sacudo 
só as mãos. Esses movimentos criam sentidos novos a partir de sua fricção com o texto.

\section{Exercício do Espelho:}

\section{Circularidade - Exploração do $\infty$ do quadril, costelas e cabeça via} técnica Beziérs.

Beziérs acredita que um dos princípios de movimento fundamental do corpo é o movimento do $\infty$ (infinito). Ou seja, a cabeça, o quadril e as costelas anatomicamente sugerem essa movimentação. Devemos reativá-la.

Primeiramente se faz uma pressão na região escolhida e começa a se fazer a movimentação seguindo a forma do infinito $(\infty)$. Após um longo tempo de exploração, 30 a 60 minutos, esse movimento está reativado e podemos começar a improvisar movimentos a partir desse estímulo.

\section{Desarticulação das Partes}

Nesse exercício, remetendo a metáfora do espelho partido, foi explorado a desarticulação das partes do corpo. Assim, o exercício era realizado em dupla, onde uma pessoa mobilizava cada parte do corpo do outro em movimentos articulares, extensões e torções. Após o toque, quem recebeu deveria experimentar movimentos a partir dessa sensação de desarticulação. A visualização da imagem do corpo em partes ajudava na improvisação.

No signo da morte explorei movimentos de colapso, de queda, de 
imobilidade. A resistência, o peso foi o ponto central para dar a idéia de prostração, de um corpo que não se agüenta mais. O silêncio traduz à imobilidade desse corpo e as quedas a angústia de lançar-se ao abismo.

Os exercícios com quedas foram feitas primeiramente a partir de um trabalho com o peso e depois efetivamente com suspensões do corpo.

\section{Exercício da Morte}

\section{Suspensão do peso}

Primeiro era feito um exercício de respiração com o corpo relaxado no chão e focando a atenção para uma região. Posteriormente, essa região era estendida ao limite e depois relaxada. A extensão ocorreria na inspiração e o relaxamento na expiração. No momento de esvaziamento do ar, o peso da região escolhida deveria ser solto e consequentemente isso resultaria em uma queda no chão. Começamos a experimentar esses exercícios de suspensão do peso primeiro nos braços, depois na pernas até chegar ao tronco e a pélvis. A única região obviamente que não experimentamos esse exercício é a cabeça.

Após o domínio das partes, passei para o exercício de suspensão do corpo todo.

Fiz uma cena em menção à obra Meshes of Afternoon de Maya Deren. $\mathrm{Na}$ cena, me visto toda de preto, até meu rosto está coberto - desvelando qualquer identidade - e no lugar da face carrego um espelho que reflete a todos. A morte que reflete a todos por onde passa como num rito de passagem. 
A exploração do movimento a partir de uma matriz simbólica é uma etapa essencial nesse processo de criação, pois se trata de investigar um signo e desdobrá-lo de outros significados, potencializando a expressividade corporal e o ato de criação e não reproduzindo movimentos já codificados. Dessa forma, a morte se desdobra em quedas e silêncios, a faca se desdobra em espasmos, ampliando as potencialidades de significado desses símbolos. Assim, se geram resignificações no corpo do ator a partir de códigos fixos, mas que não perdem o conteúdo simbólico, pois a dinâmica do movimento é preservada.

A qualidade de movimento, a circularidade, as quedas, desse modo, propiciam um signo maior para o corpo do ator na composição de uma dramaturgia corporal que contemple a dinâmica do símbolo inicial e não a sua forma física. Afinal esse é um projeto que visa à criação, a exploração de novas possibilidades, de resignificações do corpo e não a reprodução de padrões e códigos já estabelecidos.

\section{Exploração corporal dos Arquétipos Escolhidos}

\section{Oxumaré}

A serpente contém fisicalidades de movimento interessantes de serem trabalhadas, pois dão impressão traiçoeira para essa mulher, relacionando-a com a tipologia da femme fatale ${ }^{61}$, da personificação perversa do animus ${ }^{62}$.

\footnotetext{
${ }^{61}$ Femme Fatale ( como chamam os franceses) é uma personificação negativa da anima, gerando um clima psicológico sombrio. (Jung, O Homem e Seus Símbolos, pg. 178.)

${ }^{62}$ Animus é a personificação masculina do inconsciente da mulher. (Jung, O Homem e Seus Símbolos, pg. 189.)
} 
A serpente em seu simbolismo, com referência no estudo de Chevalier é a representação da dualidade, da sexualidade profunda, do veneno, do ciclo da morte e da vida, do poder de regeneração e destruição. E a figura que eu criei detém esse poder de destruição, que se volta para si mesma, na autoaniquilação. Existe a correspondência, com a serpente - a Uróboro ${ }^{63}$ - que se auto -destrói, pois morde a própria cauda. Essa auto-aniquilação da uróboro, que instila em si mesma o próprio veneno, em movimento cíclico, é o símbolo da dialética material, segundo Bachelard: da morte e vida, do infinito regenerador.

Na conexão com a cobra: "rastejar" e "dar o bote" - respectivamente "deslizar" e "talhar" segundo Laban - foram matrizes na exploração de muitos movimentos.

No rastejar explorei corporalmente movimentos sinuosos e deslizantes e nos botes movimentos cortantes e quedas. A presença de quedas e suspensões nasceram da exploração do movimento do bote que é rápido, forte e direto.

Outros verbos de movimento foram pesquisados no corpo a partir da cobra como envolver, espreitar, alertar, engolir e hipnotizar. Abaixo segue uma tabela dos movimentos explorados em cada verbo.

\begin{tabular}{|l|l|l|}
\hline Verbos de Movimento & Imagem & Fator de Movimento \\
\hline Engolir & Cobra grande digerindo & Peso - Firme \\
\hline Rastejar & Cobra locomovendo & Peso - Leve \\
\hline
\end{tabular}

\footnotetext{
${ }^{63}$ Uróboro é a serpente que morde a própria cauda...é união sexual em si mesma, autofecundação permanente, como demonstra a cauda enfiada na boca. (Chevalier pg. 816).
} 


\begin{tabular}{|l|l|l|}
\hline Dar o bote/Ameaçar & Bote da Naja & $\begin{array}{l}\text { Tempo - Rápido } \\
\text { Peso - Firme }\end{array}$ \\
\hline Alertar & Chocalho da cascavel & $\begin{array}{l}\text { Tempo - Rápido } \\
\text { Peso - Leve }\end{array}$ \\
\hline Envolver/Seduzir & Cobra se enroscando & Espaço - Sinuoso \\
\hline Espreitar & Serpente em alerta & Fluxo - Contido \\
\hline Hipnotizar & Olhar da Naja & $\begin{array}{l}\text { Fluxo - Livre } \\
\text { Tempo - Lento }\end{array}$ \\
\hline
\end{tabular}

Explorei também os movimentos centrais, a partir do toque de mapeamento da coluna, pois a cobra tem um só eixo e ausência de membros e, portanto, sem movimentos periféricos.

\section{lá Mi}

As "mães ancestrais" sugeriram em sua pluralidade de características o trabalho com seu poder de sedução: um estado hipnótico.

Assim, foram feitos exercícios de desaceleração do movimento até que se chegasse a esse estado hipnótico.

\section{Exercício de desaceleração}

Tudo começava com a pressão dos pés no chão e o deslocamento no 
espaço. O objetivo era ir desacelerando a movimentação lentamente até o limite da imobilidade, com a finalidade de se chegar a um estado de flutuação, de "semi-transe", de hipnose. Esse exercício era repetido todos os dias do treinamento como base do aquecimento. Conforme se atingiu seu domínio foi se voltando, aos poucos, a aceleração, mas preservando o estado conquistado.

O trabalho de toque realizado na exploração desse arquétipo das lá Mi foi o mapeamento da região que denominamos como "asas" que engloba a clavícula, escápulas e braços. Nessa investigação foram mapeados esses ossos e utilizada a torção aplicada na técnica Beziérs. Essa região óssea foi escolhida tendo em vista o mito das lá Mi Oxorongá - as mulheres pássaros. A sensibilização, desse modo, das "asas" foram determinantes na produção de uma série de movimentos, imagens e ações que se estruturam em uma das cenas.

\section{Exercício de Mapeamento das "Asas"}

Nesse exercício é feito um mapeamento da clavícula, desde o esterno, até chegar à ligação com a escápula. O toque deve ser profundo e em torno do osso. Quando se finaliza as omoplatas é feito a torção do braço aplicada na técnica de M. Beziérs.

A sensibilização dessa região da escápula, que chamamos de "asas", pois anatomicamente o desenho ósseo se assemelha ao da asa, é intensa. Essa sensibilização resulta em movimentos muito interessantes. Abaixo segue uma foto de uma improvisação a partir desse trabalho de sensibilização. 


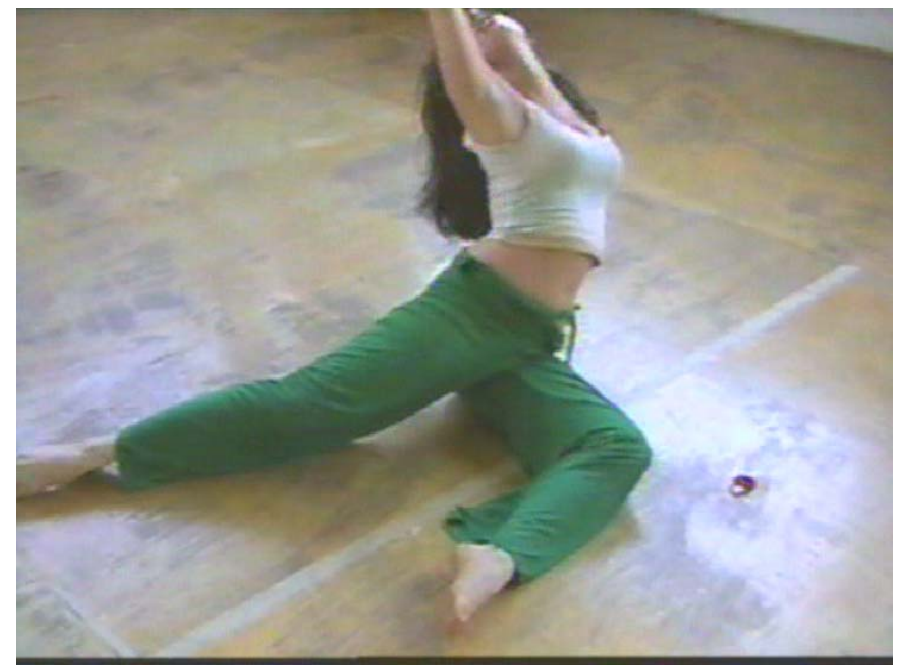

\section{Exu}

Para a vivência dessa vibração foi eleito o trabalhado com a energia animalesca. Para não repetir os verbos de ação sugeridos pela serpente, escolhemos fazer um trabalho de apoio e sustentação em quatro patas. Aos poucos essa sustentação foi repassada na relação com as paredes.

A presença dos deslocamentos em quatro patas se constitui como ação central de uma das cenas, que se alterna com quedas.

\section{Exercício com apoios}

O exercício começa com o corpo relaxado sobre o chão e com uma respiração tridimensional - costelas, peito e barriga. Nessa respiração buscase relaxar os pontos de tensão. Aos poucos, o corpo vai se movimentado lentamente, sempre buscando se alongar. Em um fluxo começa-se, então, a se buscar os apoios sem interromper o movimento. Vão se experimentando do nível baixo ao médio e ao alto.

Em um segundo momento busca esse mesmo exercício só que com o 
apoio na parede, em objetos e no corpo do outro.

\subsection{Esquematização do Material em dramaturgia}

\section{O mito da lá Mi o eixo dramaturgico do espetáculo}

Um mito das lá Mi determinou a divisão do espetáculo e sete blocos. O intuito era que transportar o percurso das mães ancestrais dado em sete tempos e espaços para sete ritos de passagem, presentes no espetáculo também. Dessa forma, esses sete lugares de passagem estão relacionados entre si na composição do todo. Assim como no Anagrama de Deren, eles podem se arquitetar por diversas composições. Esses blocos, desse modo, poderiam ser vistos em ordens variadas pois o mote que os conecta - o símbolo - permite com assumam um encadeamento livre que não se encaixa em uma lógica de sucessão. A escolha da ordem desses sete tempos na dramaturgia do espetáculo, portanto, não se dá em função de um percurso de causa e conseqüência, os motes de cada bloco são conectados pelos símbolos

- eixos centrais que conectam as linhas de passagem e possibilitam enredamentos variados. A opção do encadeamento final ocorre em função de uma necessidade de emoldurar o "caos criativo" produzindo um sentido, mas poderíamos ter feito outras conexões e gerado outra comunicação preservando os blocos intactos e apenas alterando a ordem do todo.

Abaixo segue o mito inspirados dos sete blocos:

lá Mi chegam ao mundo com seus pássaros maléficos 
Um dia as lá Mi vieram para Terra e forma morar nas árvores.

As lá Mi fizeram sua primeira residência na árvore do orobô.

Se lá Mi está na árvore do orobô e pensa em alguém, este alguém terá felicidade, será justo e viverá muito na Terra.

As lá Mi Oxorongá fizeram sua segunda morada

na copa da árvore chamada araticuna-da-areia.

Se lá Mi está na copa da araticuna da arei e pensa em alguém, tudo aquilo que essa pessoa gosta será destruído.

As lá Mi fizeram sua terceira casa nos galhos do baobá.

Se as lá Mi está no baobá e pensa em alguém, tudo aquilo o que é do agrado dessa pessoa Ihe será conferido.

As lá Mi fizeram sua quarta parada

no pé de Iroco, a gameleira-branca.

Se lá Mi está no pé de Iroco e pensa em alguém, essa pessoa sofrerá acidentes e não terá como escapar.

As lá Mi fizeram sua quinta residência nos galhos do pé de Apaocá.

Se lá Mi está nos galhos do Apaocá e pensa em alguém, rapidamente essa pessoa será morta.

As lá Mi fizeram sua sexta residência na cajazeira.

Se lá Mi está na cajazeira e pensa em alguém, tudo o que ela quiser poderá fazer, pode trazer a felicidade ou a infelicidade.

As lá Mi fizeram sua sétima moradia na figueira.

Se lá Mi está na figueira e alguém Ihe suplica o perdão, essa pessoa será perdoada pela lá MI.

Mas todas as coisas que as lá Mi quiserem fazer, 
se elas estiverem na copa da cajazeira,

elas o farão,

porque na cajazeira é onde as lá Mi conseguem seu poder.

Lá é sua principal casa, onde adquirem seu grande poder.

Podem mesmo ir rapidamente ao Além, se quiserem,

quando estão nos galhos da cajazeira.

Porque é dessa árvore que vem o poder das lá Mi

e não é qualquer pessoa

que pode manter-se em cima das cajazeiras.

Elas vieram para a Terra.

Eram duzentas e uma e cada qual tinha o seu pássaro.

Eram as mulheres pássaros, donas do eié,

eram as mulheres-eleié, as donas do eié.

Quando chegaram, foram direto para a cidade de Otá

e os babalaôs mandaram preparar uma cabaça para cada uma.

Elas escolheram sua ialodê, sua sacerdotisa.

Foi a ialodê quem deu a cada eleié

uma cabaça para guardar seu pássaro.

Então, cada lá Mi partiu para sua casa

com seu pássaro fechado na cabaça

e lá cada uma guardou secretamente sua cabaça

até o momento de enviar o pássaro para alguma missão.

Quando lá Mi abre a cabaça,

o pássaro vai, seja onde for,

aos quatro cantos do mundo ele vai e executa sua missão.

Se é para matar, ele mata.

Se é para trazer os intestinos de alguém, 
ele espreita a pessoa marcada para abrir seu ventre

e colher seus intestinos.

Se é para impedir gravidez,

ele retira o feto do ventre da mãe.

Ele faz o que lhe for ordenado e volta para sua cabaça.

lá Mi, então, recoloca a cabaça em seu lugar secreto.

Mas, se a pessoa possui um encantamento contra a feiticeira,

ele deve dizer a seguinte formula:

"Que aquela que vos enviou para me pegar, não me pegue"

Assim, por mais que tente, o pássaro não poderá executar sua tarefa.

Sua dona terá de ir em busca do auxílio das outras lá Mi.

Ela vai à assembléia e relata seu problema.

As ajés, as feiticeiras, devem trabalhar com ela,

porque não podem realizar sua tarefa sozinhas.

Então, lá Mi leva um pouco do sangue da pessoa que quer prejudicar.

Todas as outras lá Mi o põem na boca e o bebem.

Depois, elas se separam e não deixam dormir a vítima.

O pássaro é capaz de carregar um chicote,

pegar um cacete,

tornar-se alma do outro mundo,

e até mesmo pode ter o aspecto de um orixá;

tudo para aterrorizar a pessoa à qual foi enviado.

Assim são as lá Mi Oxorongá.

Esta é a sua história.

(Mitologia dos Orixás,2001,pp.351) 


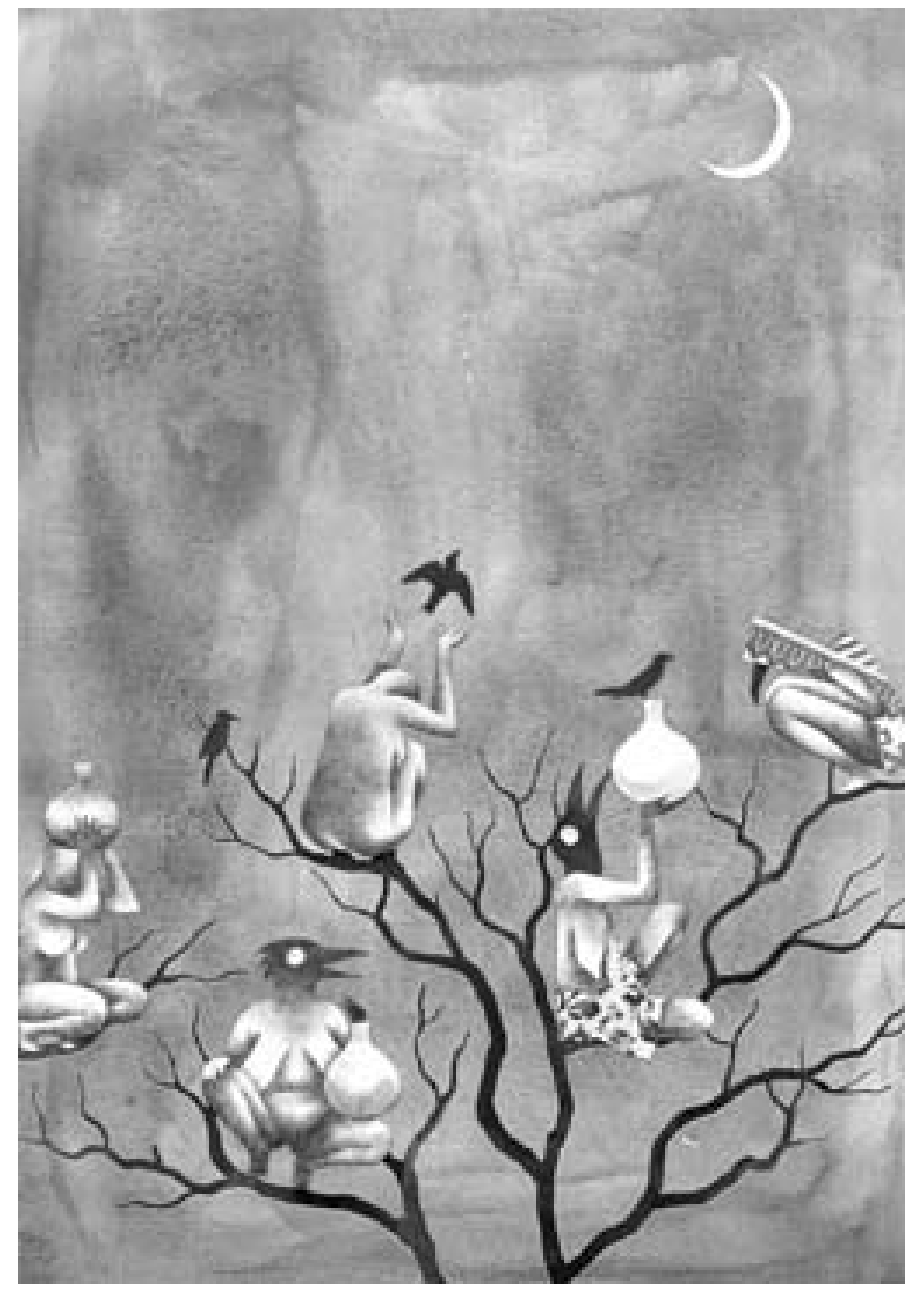

lá $\mathrm{Mi}$ - foto retirada do livro de Reginaldo Prandi - "A Mitologia dos Orixás"

Os Arquétipos - conexão de lá Mi, Exu e Oxumaré na composição da "persona" de cada bloco

\begin{tabular}{|l|l|l|l|}
\hline & Arquétipo & Persona & Tema Rito Passagem \\
\hline Bloco 1 & lá Mi & Menina/mulher & $\begin{array}{l}\text { a perda do estado } \\
\text { virginal }\end{array}$ \\
\hline Bloco 2 & Oxumaré & Multifacetada & divisão do rosto \\
\hline Bloco 3 & lá Mi/Exu & Femme fatale & Acasalamento/procriação \\
\hline
\end{tabular}




\begin{tabular}{|l|l|l|l|}
\hline Bloco 4 & $\begin{array}{l}\text { lá Mi/ } \\
\text { Exu/Oxumaré }\end{array}$ & Dividida & Envelhecimento \\
\hline Bloco 5 & Oxumaré & Animalesca & Metamorfose em animal \\
\hline Bloco 6 & Exu & Despersonalizada & Morte \\
\hline Bloco 7 & Oxumaré & Infinita & Pós- Morte \\
& & & Imaterialidade \\
\hline
\end{tabular}

\section{Os Símbolos Elegidos - influência temática e eixos dramaturgicos na Criação dos Blocos de cena do espetáculo}

Os símbolos além de permearem a investigação corporal e improvisações a partir de seus significados, funcionam enquanto elo entre os sete tempos escolhidos.

A função dos símbolos, nesse espetáculo, é essencialmente dramaturgica. Eles são a base criadora dos universos temáticos de cada cena. Toda a cena deve estar conectada em suas situações com alguns desses símbolos. Enquanto os arquétipos potencializam a construção da persona do espetáculo, os símbolos são diretamente ligados com criação da teia narrativa liminal que circunda o espetáculo.

A faca, os espelhos inteiros e partidos e a morte, desse modo, possuem em suas significações o eixo que sustenta a narrativa descontínua do 
espetáculo e nos conduz por entre suas lacunas. Eles são matrizes geradoras se sentido, sem eles teríamos figuras cênicas e energias potenciais, mas não teríamos dramaturgia. As situações e os ritos de passagem gerados são providos por sugestões temáticas desses símbolos. Assim como Deren em Meshes of Afternoon, os símbolos são essenciais como elementos geradores de sentido diante dos estados liminais que a figura central perpassa. Sem a presença dos símbolos não haveria trajetória, percurso e produção de sentido na obra de Deren e nem em meu espetáculo. São eles os mecanismos possibilitadores da comunicação com o público dentro de um obra que percute estágios liminais.

A potência do símbolo é a da organização em meio ao caos dos estágios de passagem. Afinal, todo rito de passagem se processa mediante a uma simbologia centralizadora. O símbolo é a própria coluna vertebral de um estágio liminal, ele unifica o caos gerado na passagem e atribuí a esse processo de transição um sentido universal.

Nesse contexto, utilizo o símbolo como o eixo dramaturgico do espetáculo, gerador de significados a cada bloco e elemento conector dos mesmos na produção de sentido. Afinal, Meshes of Afternoon - a inspiração desse espetáculo - se potencializa enquanto obra através do poder que o símbolo tem de reunir a criação de sentido com a criação de estados no público. Nessa correspondência com Meshes pretendo obter esse mesmo potencial do símbolo: produção de sentido e estados no espectador. 
Os 7 tempos, os 7 Ritos de Passagem - relação com os Arquétipos e Símbolos

Essa divisão do material cênico em 7 tempos, inspirado no mito das lá Mi, conduziu a proposta de elaboração de uma narrativa poética dentro de padrões sugeridos pelo Anagrama de Deren. A criação dos blocos, dessa forma, segue um fluxo independente, motivado por suas respectivas matrizes simbólicas e posteriormente se conectam com o todo em função dos símbolos que permeiam suas relações, enquanto universos temáticos.

Os símbolos na criação interferem como motes poéticos na composição do corpo do ator e como elemento de ligação entre um bloco e outro. Adiante, quando descrever as cenas ficará mais claro como esse processo ocorre.

Os blocos, portanto, se articularam e foram compostos a partir de improvisações e explorações corporais seguindo os seguintes motes:

\section{Bloco 1 - Mulher Pássaro - Rito da passagem da separação. Resgate} da Inocência

Inspiração para Improvisação - Mito das lá Mi - da passagem da menina para mulher.

Arquétipo/ Figura Cênica- lá Mi Oxorongá - a dona do pássaro.

Qualidade de Movimento trabalhada - desaceleração.

Símbolo de base temática - Espelho Inteiro 
Parte do Corpo explorada - Escápula, braços e clavícula

Símbolo de Transição - Espelho

\section{Bloco 2 - Divisão do Rosto - o multifacetamento}

Inspiração para Improvisação - Ritos de Iniciação de Pintura do rosto. Texto de Hilda Hilst Unicórnio

Arquétipo - Oxumaré ( polaridade Ying/Yang)

Qualidade de Movimento trabalhada - desaceleração, contração e expansão, movimentos súbitos.

Símbolo de base - Espelho Partido

Parte do Corpo explorada - Olhar, Cabeça, relação crânio sacral.

Símbolo de Transição - Faca

\section{Bloco 3 - Sexo - Pré Gozo, acasalamento e pós gozo}

Inspiração para Improvisação - lá Mi , aspecto mais femme fatale e texto de Hilda Hilst "Floema", trecho do acasalamento

Arquétipo - lá Mi Mapô - a grande vagina/ Exu

Qualidade de Movimento trabalhada - quedas e movimentos de pressão (com base em apoio 4 patas).

Símbolo de base - Faca

Parte do Corpo explorada - Relação entre membros, coluna.

Símbolo de Transição - Espelhos Partidos

Bloco 4 - Deus - a dialética - a tensão entre todas as forças. 
Inspiração para Improvisação - O corpo do "cavalo" - receptáculo dos orixás.

Arquétipo - lá Mi, Exu e oxumaré em tensão

Qualidade de Movimento trabalhada - contraste leve/pesado, sinuoso/direto, rápido/lento. Pressão.

Símbolo de base - Espelhos Partidos

Parte do Corpo explorada - Coluna

Símbolo de Transição - Morte

\section{Bloco 5 - A metamorfose. Animalização do humano - Mulher que se transforma em serpente}

Inspiração para Improvisação - Mito de Oxumaré que se transforma em serpente.

Arquétipo - Oxumaré - a serpente (ameaçar, envolver, afagar, engolir, espreitar, hipnotizar)

Qualidade de Movimento trabalhada - sinuosidade, movimentos súbitos e vigorosos (segundo Laban catalogados como "socar" e "talhar")

Símbolo de base - Faca

Parte do Corpo explorada - Coluna e Pélvis.

Símbolo de Transição - Espelho Partido

Bloco 6- A Morte. A libertação. A dança da Morte

Inspiração para Improvisação - Imagem da Morte em Meshes of 
Afternoon

Arquétipo - Exu

Qualidade de Movimento trabalhada - todas dos blocos anteriores em fricção.

Símbolo de base - Morte/Espelho

Parte do Corpo explorada - Todas anteriores.

Símbolo de Transição - Morte

\section{Bloco 7 - Mulher-Animal. A ressurreição da mulher selvagem.}

Inspiração para Improvisação -Texto de Hilda Hilst "O Unicórnio (trecho sobre o mar)

Arquétipo - Oxumaré - a serpente

Qualidade de Movimento trabalhada - desaceleração, sinuosidade, bote, hipnotizar.

Símbolo de base - Faca

Parte do Corpo explorada - Coluna e Pélvis.

Símbolo de Transição - Morte

\subsection{Organização do Texto de Hilda Hilst com o corpo do ator}

Nesse momento da pesquisa, após construir um texto de ações corporais ou uma corpografia, que é uma terminologia que uso para descrever um texto de ações físicas geradas por motes poéticos pessoais, eu começo a inserir 
outros elementos que vão possibilitar resignificações a partir da matriz corpórea.

Esse aflorar de simbologias será o material para a criação artística tanto para a dança como para o teatro que envolve o impulso sonoro - a conexão do corpo com a palavra. No entanto, quando o interprete cria a partir de suas idiossincrasias, o corpo e voz são fundidos, pois a expressão vem imbuída de uma motivação interna. A intenção através da respiração corporifica a palavra e gesto.

\section{Exercícios com a Palavra, com a Voz}

O exercício de desaceleração feito no aquecimento era utilizado também com a preparação vocal.

Após uma hora de caminhada contínua de desaceleração chegava-se a um limite entre a movimentação e a imobilidade. Esse estado gerava uma sensação "hipnótica". Quando atingia-se essa potência era o momento de experimentar a voz - ruídos sonoros vindos de diferentes lugares. Os sons interessantes eram selecionados e experimentados com o texto.

O texto era falado nesse mesmo estado hipnótico primeiramente da maneira mais neutra possível. As sensações provocadas nesse estado eram variadas, mas não deveriam, nesse primeiro momento, afetar a voz, gerando, em conseqüência, uma intenção. As palavras, desse modo, eram ditas uma de cada vez. Nenhuma palavra do texto poderia estar colada a outra, havia um espaço entre elas, um silêncio. Após se realizar esse trabalho muitas vezes, o texto estava completamente decorado sem nenhuma intenção, mas 
mobilizando diversas sensações produzidas por esse estado. Quando se atingia esse ponto de neutralidade começávamos a experimentar esse texto sem espaçamento entre as palavras - em um fluxo - somente com pausas respiratórias. Esse fluxo em que o texto era dito provocava diversos estados vocais. Depois de uma série de experimentações em fluxo, o texto finalmente começava a ser dito livremente, com os fluxos e espaçamentos dados pelo estado. Só após muita experimentação é que o estado da voz começava a guiar a palavra e criar um sentido próprio para cada frase.

Realizamos esse mesmo exercício como extensão da busca de uma voz despersonalizada, que fosse capaz de não se fixar em um único estado ou caractere. A voz e corpo, portanto, são integrados nesse trabalho e se potencializam na busca de uma pluralidade de sensações, imagens e ações.

Com esse foco de trabalho, acredito que no caso do ator que lida com o texto, é mais interessante investigar primeiro o corpo e voz para descobrir seus desejos e sua tessitura, a dramaturgia contida neles, para depois entrar no domínio das palavras. Assim, a imagem sonora vem como extensão do estado corporal. Afinal, a palavra deveria ser um eco das sensações do corpo.

Ao atingir a composição da dramaturgia corporal começo a perceber quais são as questões e signos que esse corpo traduz para a escolha do texto escrito. Os textos escolhidos foram Floema e o Unicórnio de Hilda Hilst.

Hilda Hilst é poeta, dramaturga e escritora. Na sua vasta obra ela lançou um olhar sobre o homem e seus desejos, tendo com traço de sua linguagem 
uma forte característica sexual e uma corrosão. A poetisa teve várias fases, uma marcada pela forte questão metafísica e outra em que chegou a ser denominada pornográfica.

Os textos O Unicórnio e Floema fazem parte do livro Fluxo e Floema e marcam uma fase em que ela fala sobre a questão da matéria e do espírito, da necessidade de transcendência. A poetisa faz uma dialética entre o corpo e seus apetites e a busca da transcendência, da iluminação.

Hilda escreve do ponto de vista da carne e do espírito, dos desejos. Sua obra é marcada por um forte caráter simbólico, em que elege símbolos que marcam sua dramaturgia. Em Floema nos deparamos com a forte presença da faca e em Unicórnio nos deparamos com a transmutação de uma mulher em um animal. No último essa mulher vai aos poucos se cansando de sua impossibilidade de compreensão nesse mundo enquanto corpo humano e aos poucos vai se transformando em um unicórnio para que pudesse alcançar a liberdade dos seus desejos. A sublimação se dá por meio da transição ao animalesco.

Ao me deparar com essas questões do ponto de vista da matéria e do espírito, com uma escrita simbólica e pelo forte diálogo em que vi entre esses dois textos e o material corporal que produzi resolvi inseri-los na cena que preparava. Em floema vi a forte conexão com a faca, o bote, o corte, o dilaceramento e a loucura dessa mulher que quer transcender seu corpo e não consegue, travando uma batalha entre a limitação de um corpo e o desejo da alma. Nessa prosa narrativa Hilda coloca uma mulher que tenta se comunicar com um homem de várias formas, mas ele não responde. Essa sensação de ausência do outro e da mulher em êxtase me remete a loucura dos 
personagens de Maya Deren, a figura que parti no princípio da criação. Pensar na trajetória da protagonista de Meshes foi importante em vários momentos para que não me perdesse, mantendo dessa maneira, um eixo narrativo. Já em Unicórnio, me sugeriu nessa mulher que se transmuta em animal uma forte conexão com a cobra (desdobramento da faca) e na partitura final, em que tinha muitos movimentos de rastejar e da alternância entre a sinuosidade e o cortante - o bote - do animal rastejante. Essa animalização do humano é algo que ficou muito presente na dramaturgia do meu corpo e "O Unicórnio" fala justamente disso e de uma mulher que tem seu rosto dividido em várias partes e que precisa encontrar uma outra forma, mesmo que não humana, para poder conviver com seu multifacetamento.

Abaixo seguem trechos dos dois textos:

" Escute, você não está ouvindo umas vozes? São as vozes dos mortos. Eles estão dizendo: não há nada a fazer, deixa a chuva cair sobre a carne, chora, chora. Fale mais da morte e dos mortos que você carrega. São tantos, rostos quadrados, lisos, bocas escuras, mãos enfeitadas de anéis. "64

\section{O Unicórnio}

"Às vezes até sonho que és uma enorme peneira, e se assim fosse, eu não ficaria descontente, sabes por quê? Eu me daria a ti, a faca se entranhando no meu peito, meu sangue na tua carne, me deitaria na tua grande peneira descansando, tua unha pontilhada, escoadouro de mim. Deitado, Haydum? A vida inteira estou batendo no teu casco, as gentes

\footnotetext{
${ }^{64}$ Hilst, "Fluxo-floema" pg. 166
} 
preparam o meu caixão, posso vê-los daqui." ${ }^{65}$

\section{Floema}

Ambos os textos contidos no livro Fluxo-floema dispõem de vários personagens que irrompem, constituindo um viés de pensamento rizomático. Diferentemente dos heterônimos pessoanos, os narradores nesse "fluxo" variam, alternam-se, metamorfoseiam-se como "cena de possessão", na qual o narrador-"cavalo" é sucessivamente tomado por entes pouco definidos, imediatamente aparentados entre si, incapazes de conhecer a causa ou o sentido de sua coexistência múltipla e dolorosa num ofício de escrita.

"Ofício" na escrita de Hilda é algo que aparece em uma função de liturgia, pois essa multidão enunciada nos textos de Fluxo-floema existe como uma espécie de cerimônia litúrgica, ritualística na busca de uma transcendência.

Os textos de Hilda contribuíram para ampliar o entendimento das ações simbólicas e proporcionar resignificações do material corporal.

A música entrou no final da composição da cena com os instrumentos bongôn $^{66}$ e jembê contribuíram para alinhavar a dramaturgia do espetáculo. Deram um aspecto cortante ao texto e reafirmaram o símbolo da navalha e da cobra.

\subsection{Composição do espetáculo}

\footnotetext{
${ }^{65}$ Hilst, "Fluxo-floema" pg. 234

${ }^{65}$ Bongô é um instrumento percussivo.
} 


\section{Bloco 1 - A perda da inocência}

Nessa cena o espelho é colocado enquanto símbolo da identidade e contemplação narcísica. O corpo da "figura" é velado com um enorme véu branco que é descoberto. O ser se coloca diante do espelho e se examina.

A cena começa com uma caminhada invertida em estado hipnótico. A trajetória de trás pra frente foi retirada a partir dos exercícios de desaceleração.

O rito de passagem que caracteriza a cena é a perda do estado do estado virginal. Esse rito universal da transformação da menina em mulher está presente em todas as culturas e é uma fonte presente em um dos mitos das lá Mi. O tema dessa perda da inocência constitui uma "persona" em cena que está descobrindo, ou mesmo redescobrindo a sexualidade. Muitas mulheres após dolorosas separações afetivas retomam esse rito de passagem - de retomada da inocência e posteriormente do erotismo.

O texto que permeou essa cena é dito perante o espelho e surge como um depoimento pessoal da própria atriz. O depoimento pessoal é uma forma de preservação da memória colocada sem mentiras e distorções diante de um espelho. Abaixo, segue um trecho do texto:

“Ontem limpei a minha casa.

E me libertei dessa parte morta de mim.

A morte andava colada em minha carne.

Pesando com tal força que esmagava meus desejos!

Tão entranhada em mim ela impedia o que estava por vir.

Deixei que o cadáver fosse com as águas de março... 
Quantos mortos carregamos e não sabemos!

Saberei eu me ver como em um espelho?

Com tal realidade, sem mentiras, sem distorções, sem nenhuma ilusão infantil E sem enganos me aceitar assim como eu sou?

Ver que o olhar que não me cabe mais!

O sorriso que não é meu. Esse sorriso congelado, esparramado...

O sorriso perdido no tempo e no espaço

Perdido em um momento foi, mas não é mais!

Em um momento que morreu

Como é bom o fim!

Que venha essa liberdade sem a ingenuidade infantil

Sem ilusões e sem pesos!

Agora posso me olhar no espelho tal como sou

Densa, nostálgica e livre!"

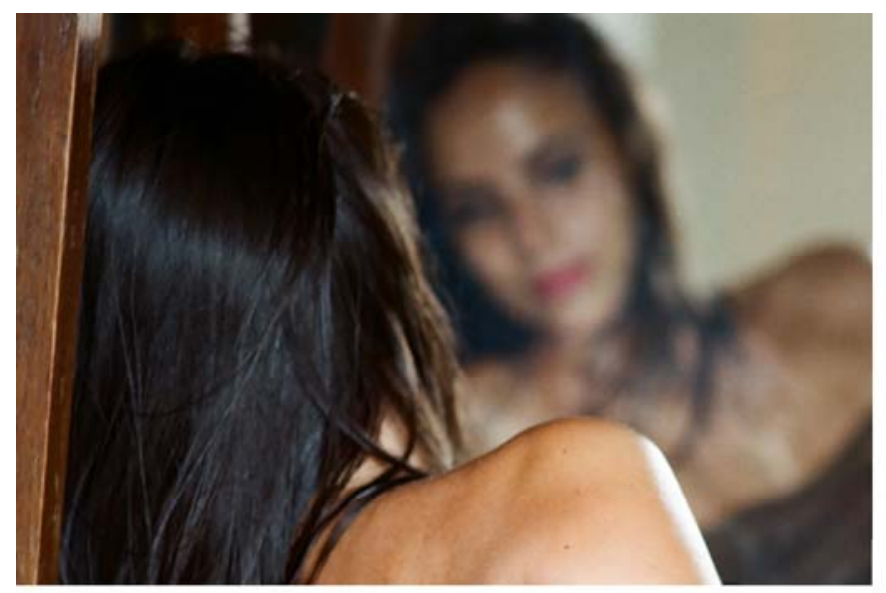




\section{Bloco 2 - Divisão do Rosto}

Nesse bloco foi introduzida uma ação de corte do rosto em três partes. Essa cena a partir de uma improvisação com a faca. Essa ação de divisão do rosto ganhou mais força quando entrou em contato com um trecho do texto de Hilda Hilst, presente do Unicórnio

" Não dê risada. Olha o meu rosto. Toca-me. Vê, ele está dividido. Onde? Olha, você traça uma diagonal partindo desta saliência do lado esquerdo da fronte, e termina a diagonal na mandíbula direita. Pronto? Bem, agora, da minha narina esquerda e portanto quase no centro da diagonal, você puxa outra linha que vai cortar o canto da boca e termina essa linha na mandíbula esquerda, formando assim um angulo de quarenta e cinco graus. Agora o meu rosto está dividido em três partes, não é mesmo? O lado esquerdo é o meu irmão pederasta, o lado direito é minha irmã lésbica e o pequeno triangulo é o meu todo que se move desde que nasci, é esse meu todo que ficou em contato com essas gentes... Olha bem estas linhas, elas dão um aspecto velho e muito triste em meu rosto, não é? Nem poderia deixar de ser assim, eu só poderia ser velha, carregando o peso desses mortos, eu tenho milhões de anos, eu tenho tantas culpas, tantos crimes no meu rosto dividido, eu sou lasciva, cruel, assassina. ${ }^{67}$

Após o momento de divisão do rosto foi introduzido um movimento coreográfico de expansão e contração súbita somada a uma ação de "golpear". A mão se expande junto ao corpo e golpeia bruscamente o chão em seu movimento de contração. Na queda a mão atinge uma bacia de tinta vermelha,

\footnotetext{
${ }^{67}$ Hilst, "Fluxo-floema" pg. 173
} 
que simboliza o sangue. A "mão que golpeia e sangra" faz a menção ao símbolo da faca como metáfora do elemento masculino modificador da matéria passiva.
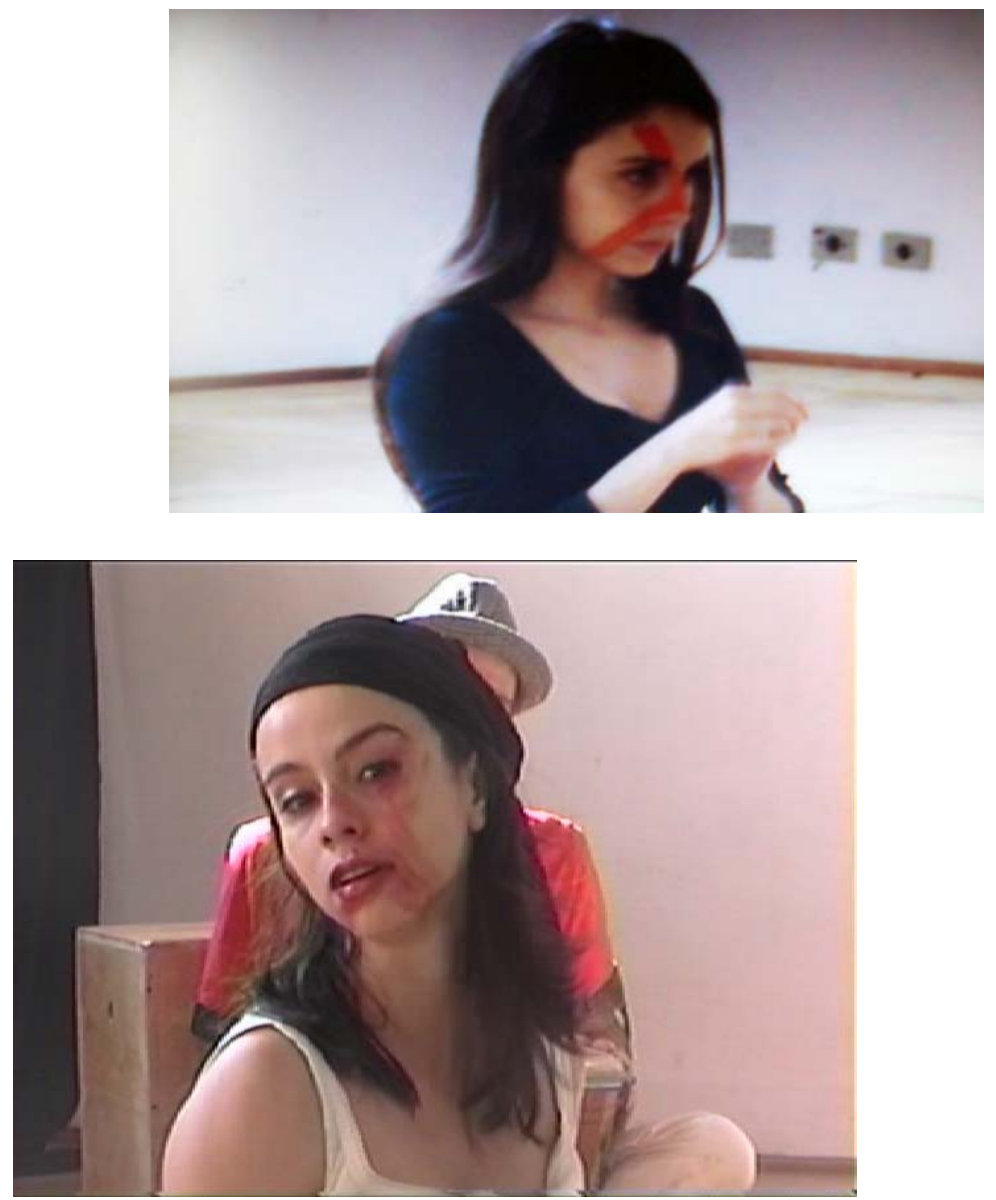

Fotos da Divisão do Rosto

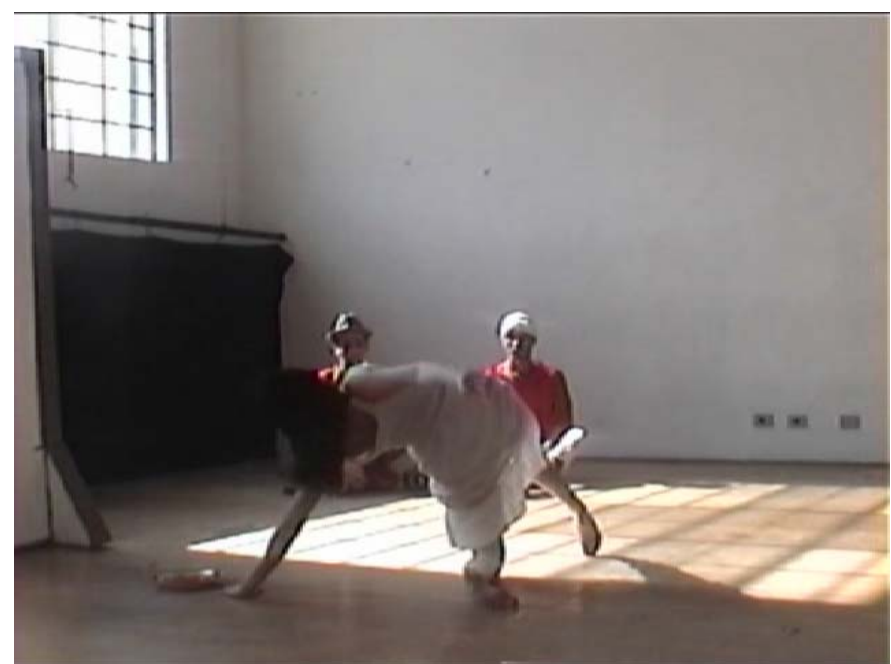

Foto "Mão de Faca" - O Golpe com a Mão (Expansão/Contração) 


\section{Bloco 3 - 0 acasalamento}

Nesse bloco eu introduzi a ação de caminhada em quatro patas derivada do exercícios de apoio, alternada com quedas.

Em seguida selecionei outra ação do exercício de queda dos braços.

Essa cena foi trabalhada essa caminhada animalesca com quedas súbitas apoiada primordialmente na energia da lá Mi. Com toda a complexidade arquetípica das "mães ancestrais" esse é um momento em que o tema é sexualidade. Assim, faz-se alusão a lá Mapô - a deusa da grande vagina.

O texto que contextualizou essas ações é da prosa Floema de Hilst. Abaixo segue o trecho escolhido.

"Tateio. Se eu te falo do mais pobre de mim, escutas? Tomo nos braços a fêmea que me deste, tateio o ventre, a coxa, o mais escuro, sobre a fêmea me deito. Tu não sabes, Haydum, o aroma da carne, a coisa dulçurosa que é o gozo, não sabes, mas nos deste o depois, esse depois da carne, a pré-memória, depois da carne a penumbra no peito, uma distância por dentro, uma coisa que pergunta: Koyo, isso te basta? Eu te pergunto, Haydum: tu sangras? Eu sim. Tateio e sangro. Há um mais fundo nas coisas que não sei. NADANADA do fundo, apenas nomes."

"Às vezes até sonho que és uma enorme peneira, e se assim fosse, eu não ficaria descontente, sabes por quê? Eu me daria a ti, a faca se entranhando no meu peito, meu sangue na tua carne, me deitaria na tua grande peneira descansando, tua unha 
pontilhada, escoadouro de mim."

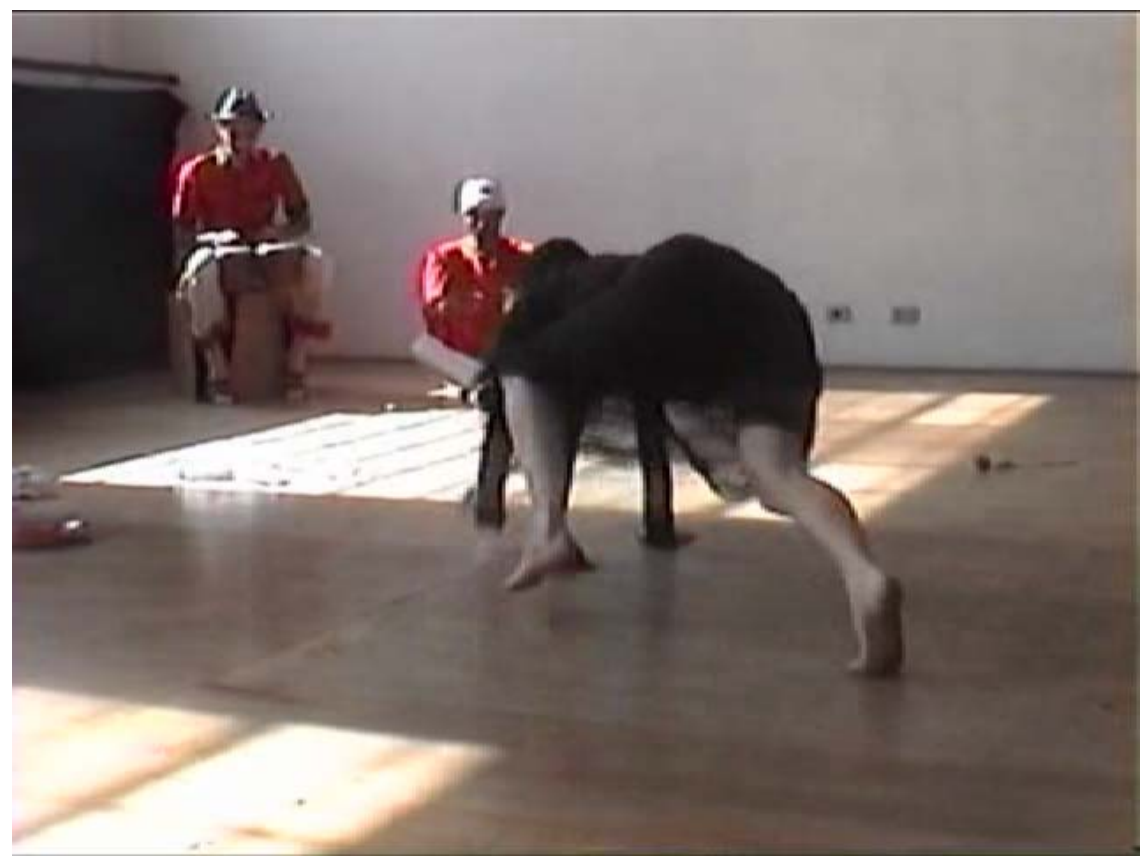

Caminhada do Apoio em quatro patas - "A Aranha"

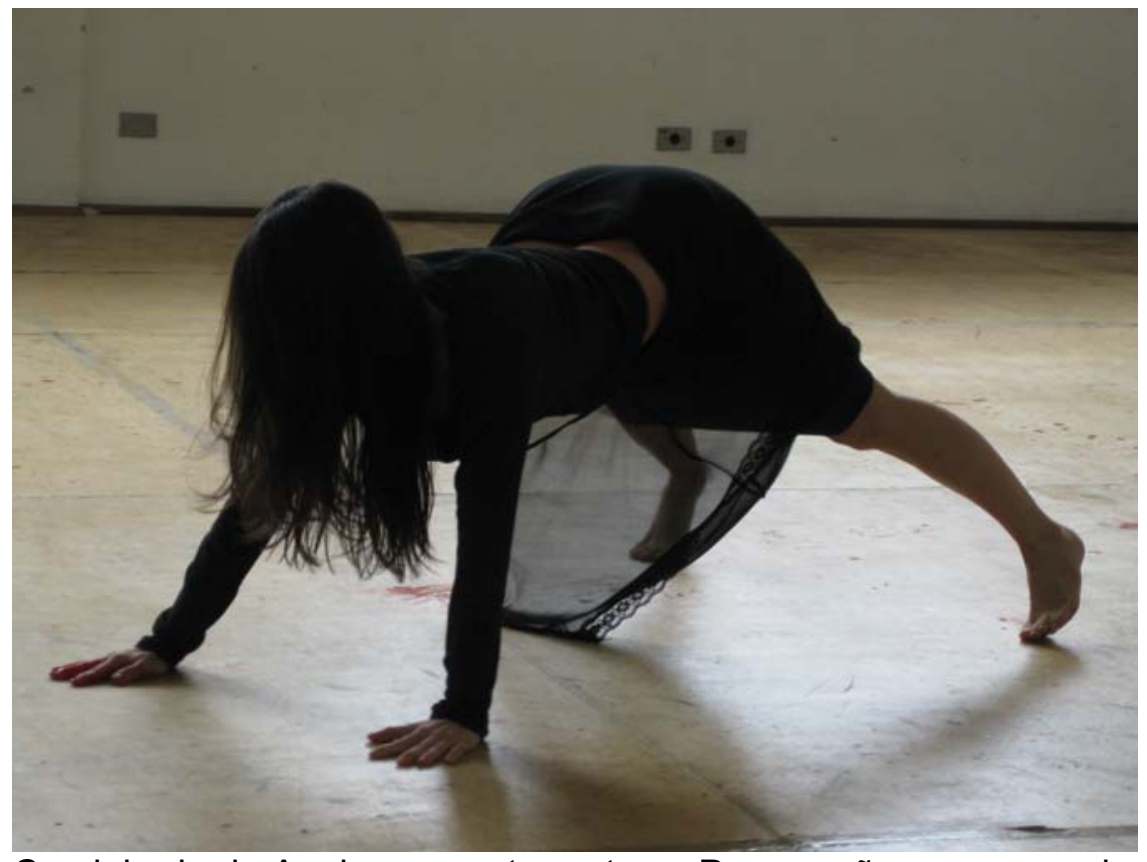

Caminhada do Apoio em quatro patas - Preparação para a queda 


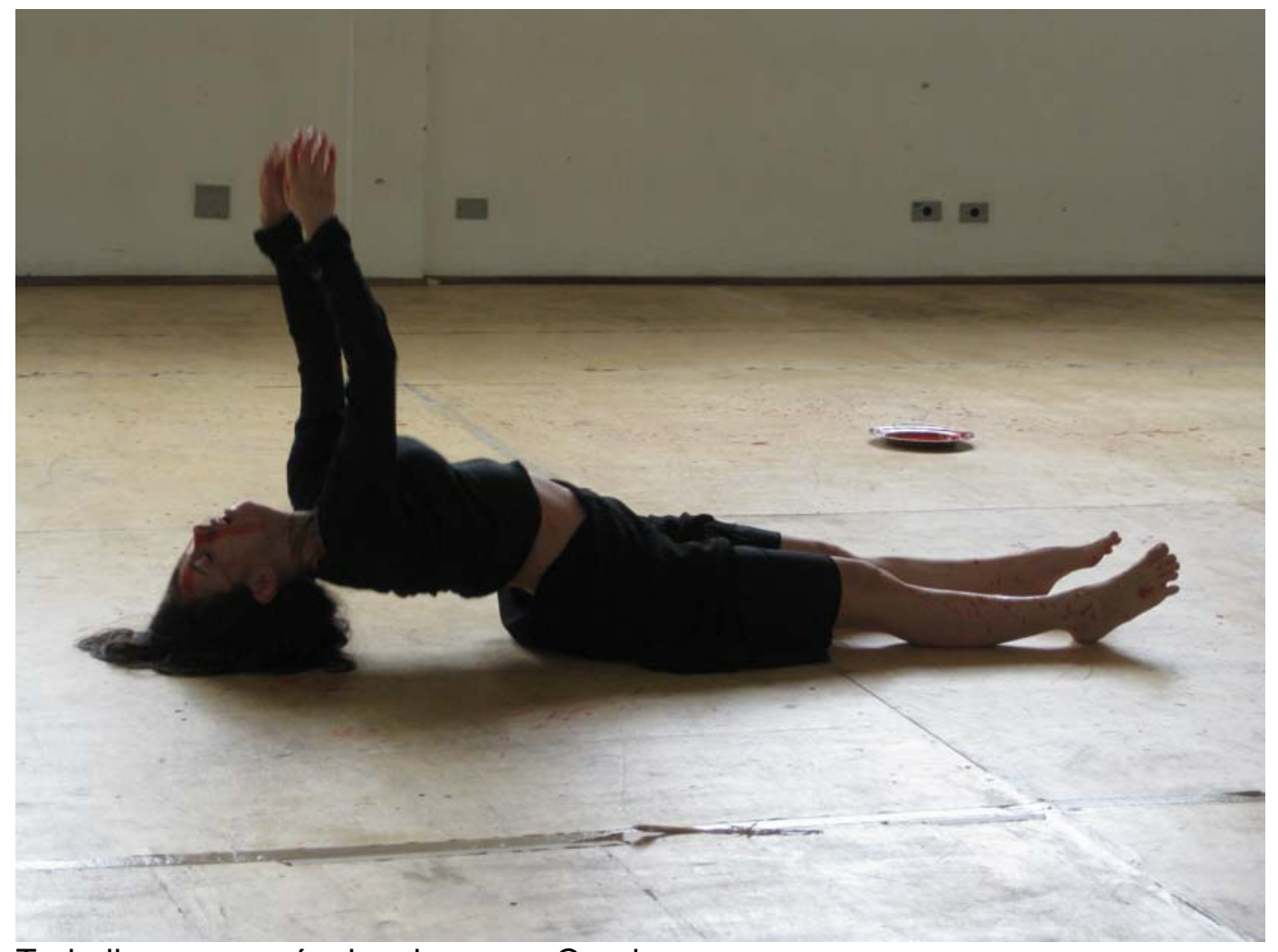

Trabalho com escápula e braços - Quedas

\section{Bloco 4 - Deus - a dialética entre forças}

Nesse bloco foram utilizados os exercícios vocais de desaceleração para constituição de duas vozes distintas que conversam entre si.

O corpo está numa situação quase imóvel. Ele escorre pela parede. Está abandonado. A imagem de prostração se contrapõe com o duelo enfático entre as duas vozes.

O exercício de desaceleração resultou em duas vozes, uma que chamamos de "provocadora" e em outra que nomeamos de "indignada". A primeira é uma voz suave, sinuosa, com a ressonância na nuca - gerou um estado que denominamos "flutuação". 
A segunda é uma voz das entranhas, acelerada, urgente, grave, direta, com ressonância peitoral e sexual - gerou um estado que classificamos "queimar" ou pegar fogo".

Essas duas vozes seguem seus fluxos de sensação e duelam em um texto que escrevi inspirado no livro Fluxo-Floema. A voz em itálico é a "provocadora" e a outra a "indignada".

- Você não ficaria desconfiada se tivesse um coração exposto e não por dentro da caixa torácica?A qualquer momento alguém podia te comer o coração!

- Alguém tem uma faca?

Quero fazer sangrar essa humanidade de coração engolido!

- Você está transpirando, vamos abrir as janelas!

- Meu coração continua exposto, eu tento esconde-lo, tento vestir outra camisa porque essa está manchada de sangue! Veja! Está manchada de sangue!

-Eu sei que é difícil no começo, mas com o tempo você vai assimilar tudo isso! É preciso que você viva primeiro, que os anos se passem, que os anos se passem lentamente. Ë preciso que se forme um certo limo sobre o corpo, é preciso sangrar as mãos! Ë preciso verter sangue! Existir é sentir dor!

Eu sinto dor e todos os dias recebo vários golpes! Golpeio-me! Atiro golpes. Existir com esse meu contorno é ferir-se, agredir múltiplas formas dentro de mim mesmo, é não dar sossego as várias caras que irrompem em mim de manhã à noite! 


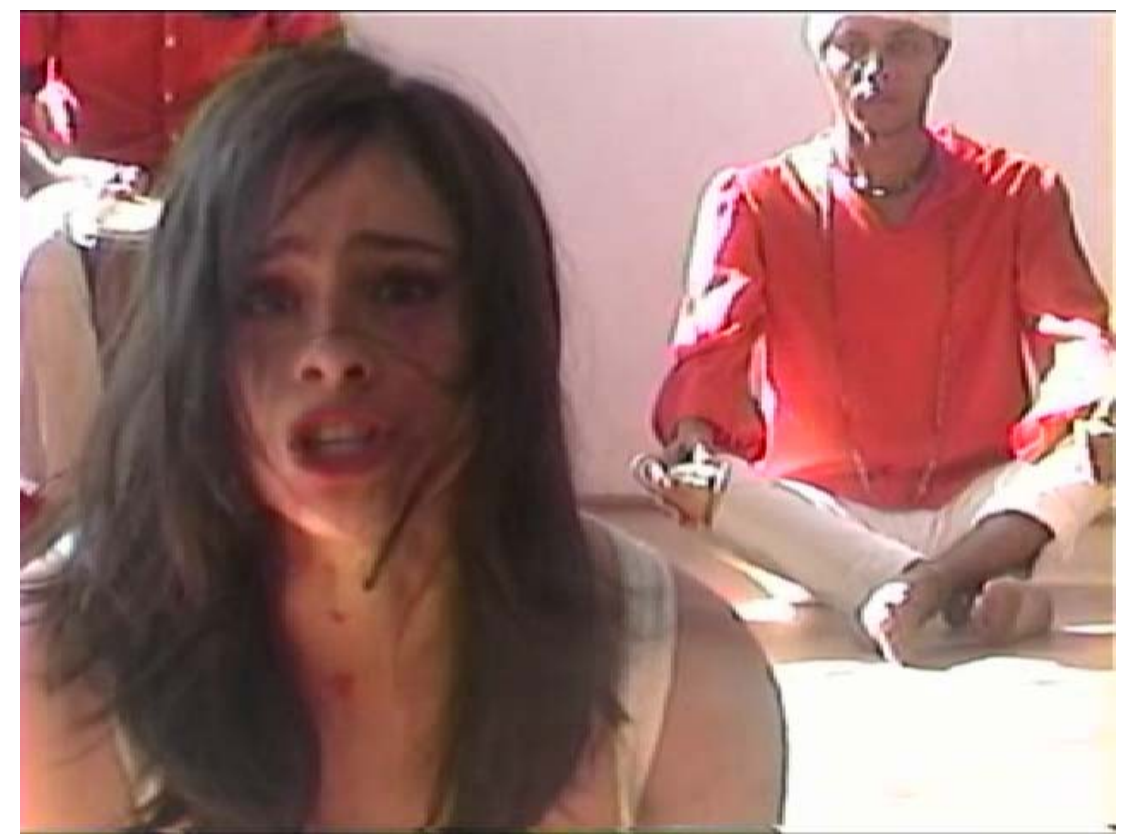

Tensão entre forças

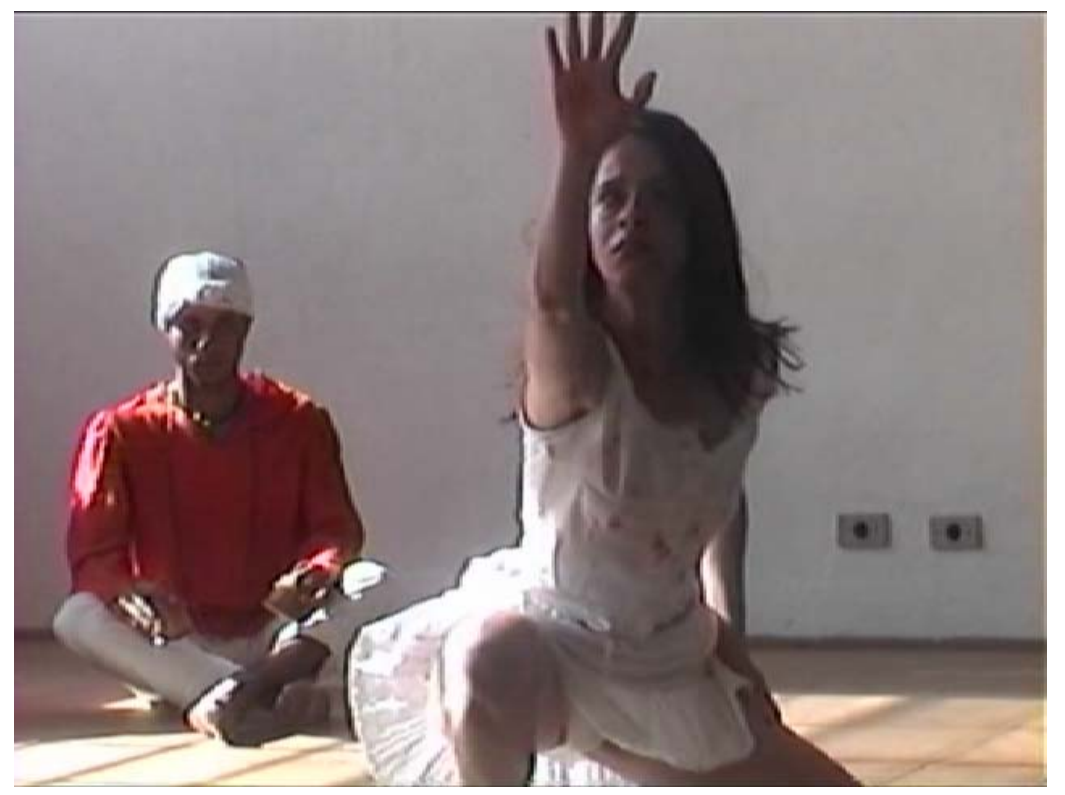

Diálogo com Deus

Bloco 5 - A metamorfose na serpente 
Nesse bloco foi formulada uma coreografia a partir de movimentos derivados de verbos de ação que envolvem a serpente - envolver, seduzir, hipnotizar, dar o bote, afagar, enroscar e engolir.

Esses verbos de ação foram explorados a partir do exercício do toque da coluna e do $\infty$ do quadril. Na experimentação forma selecionados movimentosimagem. A organização desses movimentos constitui uma coreografia, mas sem uma rigidez de tempo e ordem, permitindo em alguns momentos a improvisação livre desses verbos de ação.

A coluna é o eixo da movimentação e primordial para exploração dessas qualidades da serpente.

Nesse bloco não há texto, apenas o corpo fala em seu fluxo de sensações - na dança de metamorfose da mulher em serpente.

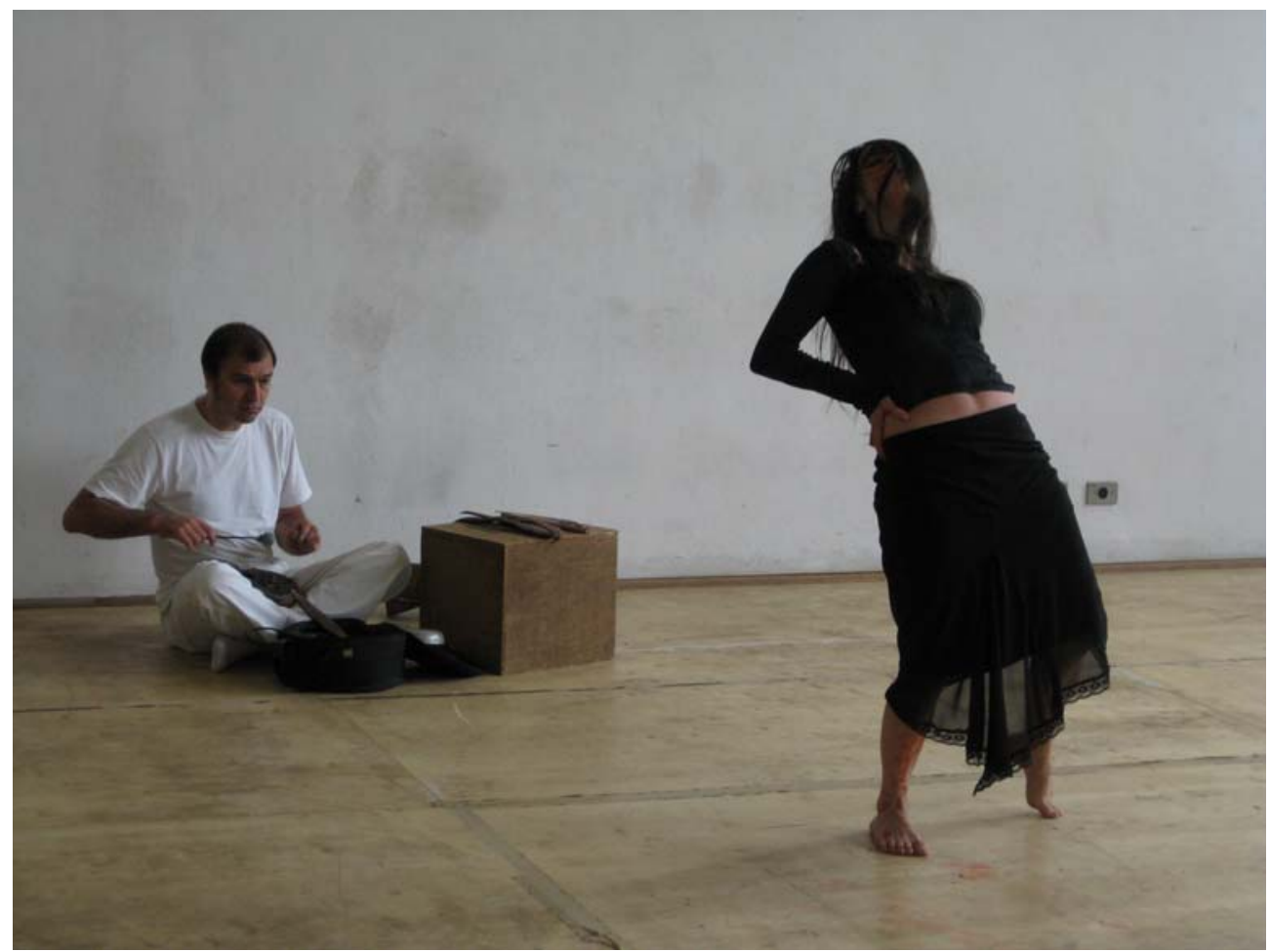

Animalização - Trabalho com a Coluna e Pélvis 


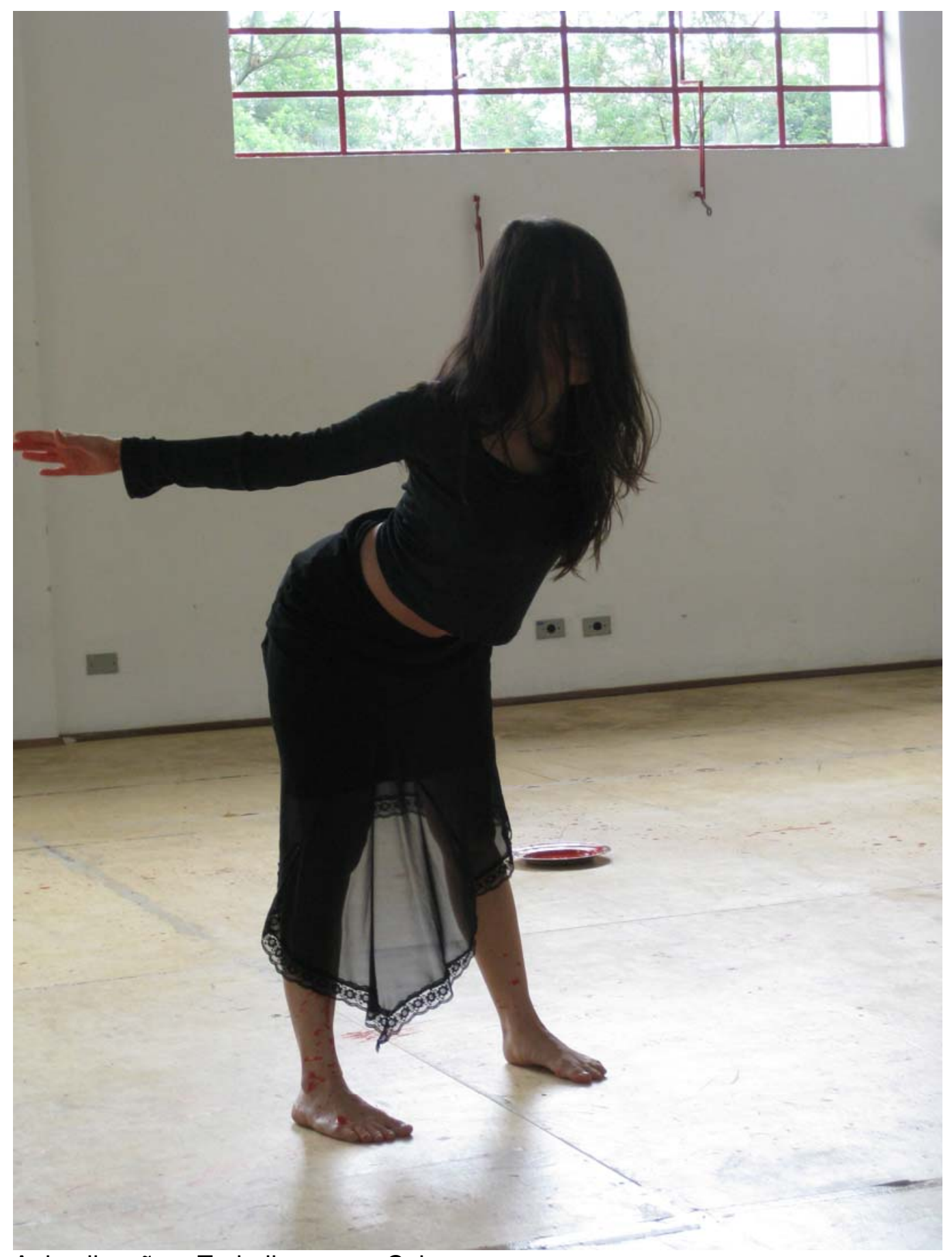

Animalização - Trabalho com a Coluna

\section{Bloco 6 - A morte}

Após a animalização da figura feminina no bloco anterior ocorre a morte. A morte da "persona" a partir de sua metamorfose na serpente. 
Nessa cena, em menção ao símbolo da morte em Meshes of Afternoon eu apareço de preto e com um espelho na face. Em seguida, deposito o espelho no chão e começo a "dança da morte". Essa dança é na verdade uma seleção de vários movimentos dos blocos anteriores - as ações em fluxo dos ritos de passagem da "persona" feminina do espetáculo.

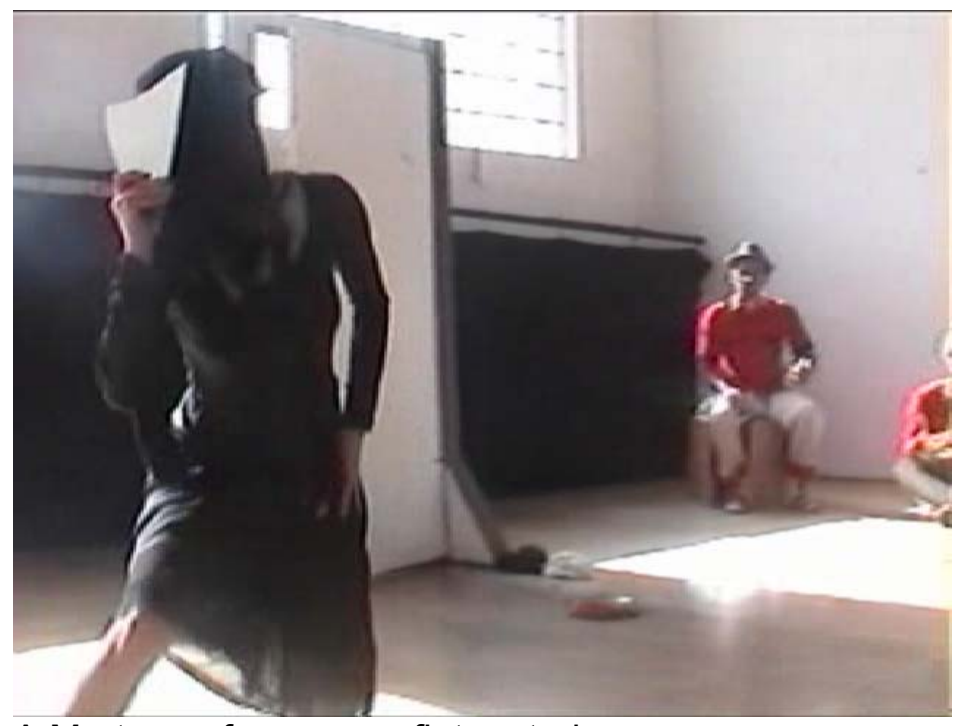

A Morte - a face que reflete a todos

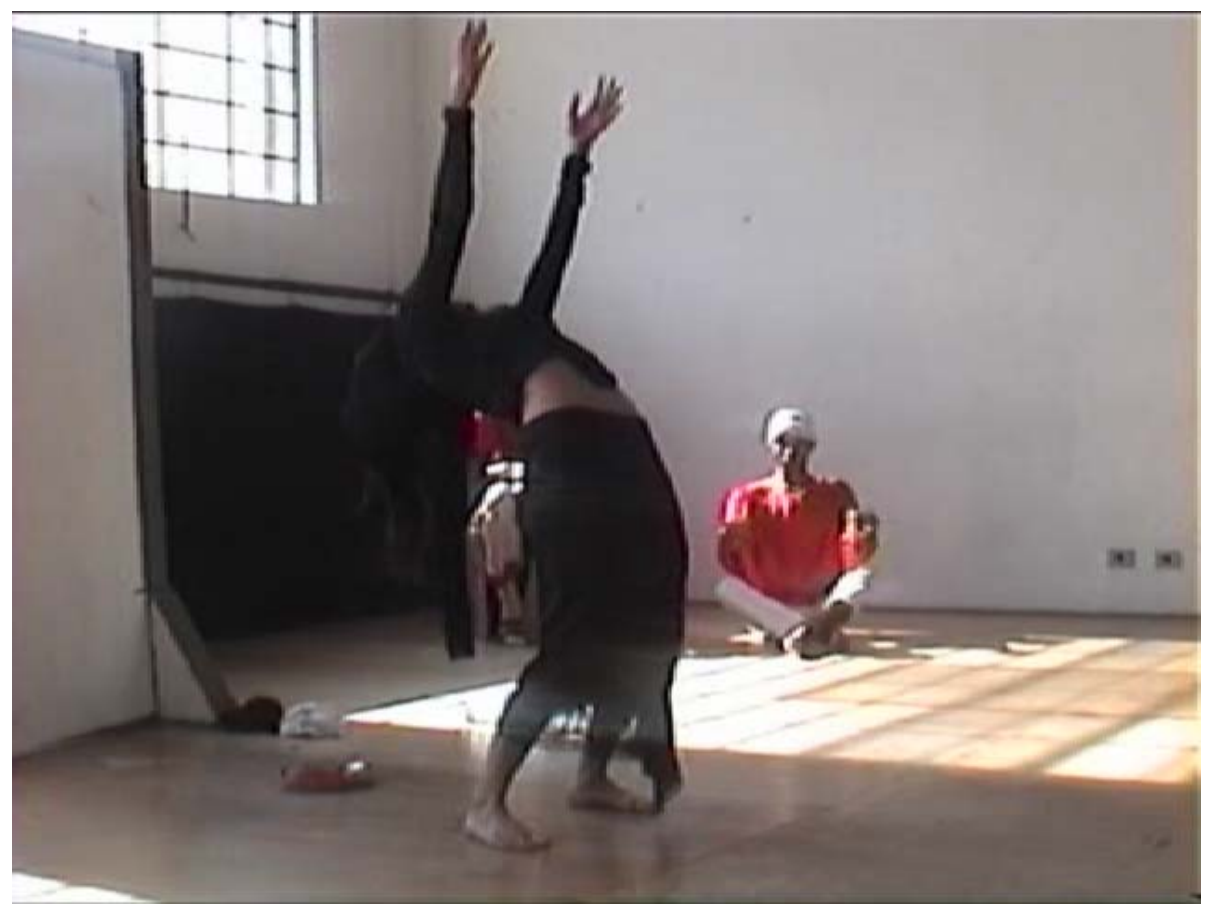

A dança da Morte - Trechos de Exploração de Movimento ao longo do Processo 


\section{Bloco 7 - A serpente}

No último bloco existe um corpo animalizado e nu, onde há uma dança com uma cobra. Essa cobra será retirada de uma gaiola, coberta com um pano ao longo de todos os blocos e nesse aparecerá para a dança final. 


\section{Considerações Finais}

Essa investigação buscou em todas as suas escolhas uma radicalidade das suas propostas. A descoberta desse corpo despersonalizado ambivalente, em tensão entre forças opostas, não é algo inovador, pelo contrário, é o tema central de investigação do corpo do ator no teatro contemporâneo.

Essa pesquisa se dedica apenas a fazer uma reflexão da presença do mito, rito e despersonalização no teatro, no candomblé e no cinema. O tema central desse corpo múltiplo é interdisciplinar e afeta profundamente o trabalho do ator-pesquisador hoje.

A experiência criativa desse projeto se amparou na multiplicidade e buscou seus próprios caminhos - ressonantes na verticalização da pesquisa e na composição final do espetáculo, onde as escolhas estéticas e dramaturgicas foram extremadas.

A busca continua incessantemente, essa investigação é um processo que não se finaliza nessa dissertação. O mergulho persiste, apenas chega um momento em que se faz necessário "emoldurar o caos criativo", gerar uma territorialização da experiência, para em seguida, prosseguir a busca com uma nova desterritorialização. 


\section{Anexo}

Mitos e Imagens Inspiradoras 


\section{Textos de Hilda Hilst - Aparatos Inspiradores}

Koyo, emudeci. Vestíbulo do nada. Até. ... onde está a lacuna. Vê, apalpa. A fronte. Chega até o osso. Depois a matéria quente, o vivo. Pega os instrumentos, a faca, e abre. Koyo, não entendes, vestíbulo do nada eu disse, aí não há mais dor, aprende na minha fronte o que desaprendeste. Abre. Primeiro a primeira, incisão mais funda, depois a segunda, pensa: não me importo, estou cortando o que não conheço. Koyo, o que eu digo é impreciso, não é, não anotes, tudo está para dizer, e se eu digo emudeci, nada do que eu digo estou dizendo. Umas coisas são ditas compulsoriamente, por exemplo isso pega a faca e corta, eu quero que pegues, quero que cortes, depois o que eu disser dos paredões da mente, escolhe o mais acertado para o teu ouvido. Agora corta. Koyo, é simples, no fundo é tudo igual, o núcleo, entendes?O núcleo, pelo menos na aparência, é igual a todos os núcleos. Tenho o comprimento da minha casa, não hei de crescer mais. Não tenho entendimento com os vivos, sempre soube dos mortos, ou sei da tua sombra, nunca sei de ti, desse que come e anda, desse que diz que é dor. Koyo, o pórtico vedado nada sei, NADANADA do homem, se estás à minha frente nem te vejo, melhor, só sei de ti porque subiste na minha unha e levantei o pé, és assim mesmo? Eu não te fiz assim quando te fiz, éramos iguais em tudo. Antebraço de pedra, peito extenso. Não sei de abóbora, Koyo, me diz como ela é, fiz muitas coisas e agora não me lembro, fiz umas coisas peludas, outras incandescentes belo o pêlo, belo o fogo, fiz muitas coisas redondas, quase tudo, mas talvez só entendas o semicírculo, não vês que continua mais abaixo e assim se fecha em 
círculo. Mas abóboras, não sei. É matéria calada, ou fala como tu? Tu pões coisas na boca, trituras com os teus dentes e depois jogas fora? Eu não te fiz assim. Alento, gozo de abrir e fechar, gozo do movimento, para gozares sempre. Preenchi o vazio com o que tive à mão. Não sei nada das coisas que me dizes. Tentemos. Um dia, a lagarta se aquecia. Olhei-a, mas não como pensas sobre o olhar, pensei largo: lagarta se aquecendo, pena que não seja como o fogo, pensei pena. Soprei. Não como sopras, nem como pensas o sopro, e da omoplata direita saíram duas lagartas. Koyo, descansei, mas no descanso também sofro dessa angústia de ser, e no escuro da noite ME PENSEI. E vi matéria vasta, e quando digo matéria já te penso pensando na matéria em que pensas. Não é como tu pensas. Tive certeza de que um outro igual a mim, um outro pleno, se faria ao meu lado. Koyo, não entendes, não posso ter pensado assim, insistes na garganta, mas foi apenas um instante que pensei preencher algum vazio. Corta, Koyo, estou intacto, desde sempre sou esse que tu vês. Não vês? Afunda com mais força, levanta acima da cabeça o teu punhal, golpeia muitas vezes. Desde o início te falo emudeci, e nada me propões. Qual é o pé onde estás? Ou apenas te espichaste? Repito: tenho o comprimento da minha casa. Se por acaso estás aí onde disseste, é porque tens alguma coisa a resolver comigo. Fala mais alto. Poucas coisas te peco e tão pequenas. Tens a faca, abre já te disse. Usa esse de nove miligramas, esse que acaba com o todo. Alguma coisa deves renunciar, luta comigo. Tenta. Quem sabe se me enganas, falas do teu esforço, mas não estás deitado? Usa a linguagem fundamental, usa o esteio, o formão sobre o cobre, usa o teu sangue, estás me ouvindo?

Até o mais fundo? Vai gritar, emudeceste apenas no mais fundo. No 
centro? E que faca é a melhor? Essa da carne? Essa do pão? Cada vez mais difícil, nem sei o que tu dizes, nem onde devo cortar, se eu soubesse que um dia ficaria à tua frente, bem, não estou, um pouco mais abaixo mas presente, se eu soubesse que um dia isto seria assim, teria estudado bem anatomia. E se de repente eu corto e ainda não aprendeste o suficiente? Se de repente eu corto e estás em formação, de nada adiantará cortar. Sabes como é na morte com o cabelo e a unha? E então, se de repente pensas que está formado por inteiro, e não estás e eu corto, e o teu de dentro continua a crescer indefinidamente, então não devo cortar, entendes? E se a tua pituitária é deficiente? Se fores um anão por dentro? Isso do tamanho da casa não importa, tudo é aparente, ainda há pouco disseste. Imprecisão, matéria bifurcada. Haydum, o que chamamos de faca é brinquedo para a tua espessura. És grande, nem sei como igual a que, no teu olho passeiam minhas crianças, espelham-se no teu olho, Haydum. não posso, nem te vejo, quero dizer vejo a tua unha, não inteira, apenas piso na tua unha, quero dizer passeio, quero dizer que estou de pé na tua unha. E como posso cortar a tua fronte? Olha como treme a minha mão. Tremo, só de pensar o que podes.

Te falei das minhas crianças que se espelham no teu olho, dia a dia me perseguem dizendo: pai, o grande olho espelhou nosso rabo, temos a cor da víscera, somos crus abaixamos em vão nossas cabeças, tu disseste, pai, que a cabeça dos homens é antena, antena esfaimada de futuro, tu disseste que AQUELE GRANDE nos vê, assim como nos vemos, e só vemos o rabo, pai, a víscera, a crueza, não vemos a cabeça, com que olho é que olhamos se abaixando a cabeça para o espelho do GRANDE não nos vemos? Vejo o teu casco, Haydum, superfície embaçada, vejo, deixa-me ver: impenetrável, estou 
usando a faca e apenas sai poeira, não consigo um milímetro de carne debaixo da tua unha. Matéria pontilhada. Às vezes até sonho que és uma enorme peneira, e se assim fosse, eu não ficaria descontente, sabes por quê? Eu me daria a ti, a faca se entranhando no meu peito, meu sangue na tua carne, me deitaria na tua peneira descansado, tua unha pontilhada, escoadouro de mim. Deitado, Haydum? A vida inteira estou batendo no teu casco, as gentes preparam meu caixão posso vê-los daqui. Nem sabes como somos prudentes. Tenho o peso de mundo, tudo pesa e tudo se me fecha, os outros me comprimem, êmbolo, sou sempre o de baixo, que seiva é para sugar? Quem é que suga aquilo que não vê? A língua é presa num filete rosado de matéria, é áspera, pesa na minha boca, tudo pesa, a maior parte do dia fica à procura de migalhas depois se distende procurando a palavra. PESA. E há pássaros, Haydum, esses que tu fizeste para mim emudecidos. Palatino sonoro, sim, mas se devoram, uns maiores, têm garras, andam aos bandos, parecem frágeis ao longe. São momentos do todo onde resides? Te sabem? Se eu pudesse ver como tu vês, de todos os lados, dentro da chama e pudesse gritar com outra garganta. Tateio. Se eu te falo do mais pobre de mim, escutas?

Surdo-mudo Haydum, chacal do medo, vilão, ainda te agarro, ainda hei de me adentrar no teu de dentro, e ter fogo para cortar, não ficarás para sempre no gozoso, na tua própria matriz indevassada, gozando teu saber, Haydum-Hiena, a mim me devorando. Dá-me tempo. Num instante anoitece. A garganta vibra. Será preciso cantar? Além de tudo, do cansaço, do nojo, da fatia de carne que sou, todo exposto, além de tudo devo, dizes, começar o Domine e dizer que sois a verdade. E eu a vida? Dá-me tempo, preciso raspar as pernas porque os moluscos do cerco grudaram-se a mim, devo trancar o 
cabelo, uma só trança na nuca, ponta sobre o rim, agora limpo o ouvido para melhor te escutar. Desde que me sei te ouvindo, sofro um prurido nos pequenos canais, um dó mi repetido: AGORA AQUI. Isso quer dizer que a minha pergunta no tempo é igual à mosca que tomba? E o de antes é nada? Perco o meu faro, não sei mais do meu ninho, penso que devo lançar ao charco a bússola de sempre, às vezes aponta para o pé, digo sei, é na unha de Haydum que construo meu passo, depois aponta para o alto, digo não sei, não posso ir até a fronte, não tenho meios, nem bisturi, nem broca, e as luvas deixei-as no armarinho branco do banheiro, porque pensei, ainda penso que me preferes agudo, a ponta dos meus dedos, aí por onde escapa o mel de dentro, ainda penso que um NADANADA de mim, um MUITOPOUCO te percorra, e entendas esse que se amolda dentro de meu corpo, esse, protonauta vivo, vermelho. E se esse escapa quando eu te abrir a fronte? Haydum, talvez não deva, mas digo: alguém antes de mim usou a faca? Expeliste o vivo? E agora és uma casca?

CAMINHO, CAMINHO, os ossos à mostra. Haydum, um gozo não me tiras: NADA-NADA de mim quando me tomares, nem os ossos. Estou novamente no centro, as paliçadas ao redor, esta casa-parede avança, vai me comprimindo. Porco-Haydum: tentei.

\section{Mitos do Candomblé}

\section{Mito de Oxumaré}




\section{Oxumaré transforma-se em cobra para escapar de Xangô}

Certa vez, Xangô viu Oxumarê passar, com todas as cores de seu traje e todo o brilho de seu ouro. Xangô conhecia a fama de Oxumarê não deixar ninguém dele se aproximar. Preparou então uma armadilha para capturar Oxumarê.

Mandou uma audiência em seu palácio e, quando Oxumarê entrou na sala do trono, os soldados chamaram para a presença de Xangô e fecharam todas as janelas e portas, aprisionando Oxumarê junto com Xangô.

Oxumarê ficou desesperado e tentou fugir, mas todas as saídas estavam trancadas pelo lado de fora.

Xangô tentava tomar Oxumarê nos braços e Oxumarê escapava, correndo de um canto para outro. Não vendo como se livrar, Oxumarê pediu a Olorum e Olorum ouviu sua súplica.

No momento em que Xangô imobilizava Oxumarê, Oxumarê foi transformado numa cobra, que Xangô largou com nojo e medo.

A cobra deslizou pelo chão em movimentos rápidos e sinuosos. Havia uma pequena fresta entre a porta e o chão da sala e foi por ali que escapou a cobra, foi por ali que escapou Oxumarê.

Assim livrou-se Oxumarê do assédio de Xangô. Quando Oxumarê e Xangô foram feitos orixás, Oxumarê foi encarregado de levar água da Terra para o palácio de Xangô no Orum (céu), mas Xangô não pôde nunca aproximar-se de Oxumarê 


\section{lá Mi reconhece o poder dos homens sobre o poder feminino (Mito da transição do matriarcado para o patriarcado).}

Ogum, Obatalá e Odu vieram do Orum. Eles rumavam para a Terra, mas antes foram consultar Olodumare.

Ogum veio na frente com seu sabre, com seu fuzil, com tudo para a guerra, Cheio de poder.

Depois veio Obatalá- Obarixá,

Com o poder de fazer tudo o que quisesse.

Por fim veio Odu, que era a esposa de Orunmilá .

Olodumare the conferiu o poder de dar vida na Terra,

De ser a mãe de todos.

Olodumare Ihe deu o poder do pássaro e cabaça para guardá-lo.

Mas pediu-lhe moderação quando estivesse na Terra.

Odu afirmou que sim,

Que usaria para o bem e para o mal,

Conforme fosse necessário.

Olodumare confirmou o poder de Odu sobre os homens.

Eles Ihe seriam submissos.

Odu era a mãe de todos.

Odu é a nossa mãe ancestral, lá Mi Oxorongá.

O homem dependeria da mulher, sempre,

Para fazer o que fosse.

Mas Olodumare advertiu Odu

Que o poder que ele the dera não poderia ser usado com violência. 
Odu, contudo, utilizou seu poder com imprudência

E não obedeceu ao dito de Olodumare.

Ela profanava as florestas de Egum, o antepassado do homem,

E as florestas de Orô, o orixá caçador.

Ela entrava em seus proibidos locais de culto.

Ela se recusava a fazer oferenda.

Ela se apropriava dos panos que cobriam Egungum.

Por mais que lhe pedissem para usar seu poder com calma,

Odu se recusava a ouvir

Então, Obatalá consultou Orunmilá

Em busca de resposta para o abuso de poder de Odu.

Olodumare enviou resposta para Obatalá.

Que ele fizesse oferendas.

Que tivesse paciência,

Pois a Terra seria dele e Odu Ihe seria submissa,

Porque ela exagerara no uso do poder que Olodumare lhe confiara.

Então, naquele tempo, Odu e Obatalá moraram juntos,

Mas Odu nunca mostrava o segredo do seu poder a Orixá.

Um dia, Obatalá deu sangue branco do caracol para Odu beber.

Odu gostou muito daquilo, pois sentiu-se calma.

Odu achou delicioso o sabor do caracol.

Ela estava muito calma

E Orixá aproveitou-se para dizer que Odu o entristecia,

Porque não lhe mostrava nunca seu poder

Só ele, Obatalá, é que mostrava tudo o que fazia. 
Então, Odu chamou Orixá para adorar Egum.

Odu levou as coisas com que adorava egum

E entrou na floresta para adorar Egum.

Obarixá a acompanhou assustado.

Ele viu com Odu se cobria com os panos de Egungum,

Mas Odu não sabia fazer a voz cavernosa de Egungum.

Odu só sabia cobrir-se com as vestes dele e fazer evoluções.

Odu não conseguia fazer a voz profunda de Egum, era mulher.

Quando eles voltaram para casa,

Obatalá retornou secretamente para o local da oferenda.

Ele acrescentou uma rede ao pano de Egum

E arrastou o chicote no solo.

Todos se apavoraram e Odu ficou muito assustada com aquilo.

Obarixá-Obatalá então rodeou toda a cidade

Como se fosse Egungum vindo do Além.

Odu, porém, reconheceu que o pano era o seu.

Ela suspeitou de Obatalá, ele não estava em casa.

Odu mandou seu pássaro pousar no ombro de Egum.

Tudo o que Egum dizia, então,

Era pelo poder do pássaro.

Assim, depois de devolver as coisas de Egungum,

Obatalá voltou para casa

O pássaro de Odu já voltara antes dele.

Odu então saudou Obatalá e viu todas a coisas que ele recebera.

Odu confirmou que Obatalá vestira seu pano de Egum. 
E Odu viu que seu pano de Egum era conveniente a Obatalá,

Pois todas as pessoas acreditaram que era egum que lhes falara

Odu deu então seu pano de Egum para Obarixá,

Pois concluiu que vestir-se com os panos de Egungum

Era mais apropriado aos homens que às mulheres.

Odu dali em diante apenas dançaria

Na frente de Obatalá vestido com o pano de Egum.

Esse seria o papel da mulher,

Pois a mulher tinha poder demais na Terra.

É pela mulher que todos vêm ao mundo.

Mas Odu reconheceu que o homem,

Com astúcia e inteligência,

Tomou da mulher o seu poder

\section{Exu não consegue vencer a Morte}

Havia um ser que não temia Exu e este era Icu, a Morte.

Icu ouvira falar de coisas terríveis que Exu tinha feito ao povo

E perguntou por que Exu fazia isso sem ser reprimido.

Todos diziam que ninguém era suficientemente corajoso

Para enfrentar Icu face a face.

Icu disse que era ela quem devia lidar com Exu

E enviou uma mensagem desafiando Exu para uma batalha.

E Exu então respondeu:

"Eu não tenho medo de Icu. Vamos lutar". 
Exu foi até seu amigo Orunmilá e contou-lhe sobre o desafio.

Orunmilá perguntou:

"Quem pode lutar com a Morte?"

Exu respondeu bravo:

"Quem pode lutar com Exu?"

Exu pediu a Orunmilá que arranjasse o combate.

E o dia do duelo chegou.

Veio gente de toda parte para assistir ao duelo

E a cidade ficou tomada de espectadores.

Exu bradou seu grito de guerra provocando Icu.

Então Icu avançou, segurando a espada e o escudo,

E cantou provocando Exu.

E a batalha começou.

Exu golpeava forte com o porrete, várias vezes.

Mas Icu era rápida e ágil.

Tanto que Icu prendeu Exu.

Icu jogou-o no chão e arrancou o porrete de sua mão.

Icu ergueu o porrete sobre Exu para matá-lo.

Então houve gritos na multidão.

Orunmilá correu até o lugar da escaramuça

E tomou o porrete de Icu, salvando o amigo da destruição.

E foi porque Exu foi defendido por Orunmilá que ele não morreu.

E é por causa disso que os homens dizem:

"Ninguém pode matar a Morte.

Ninguém pode derrotar Icu". 


\section{Inspirações Imagéticas}

\section{Sobre Deren}

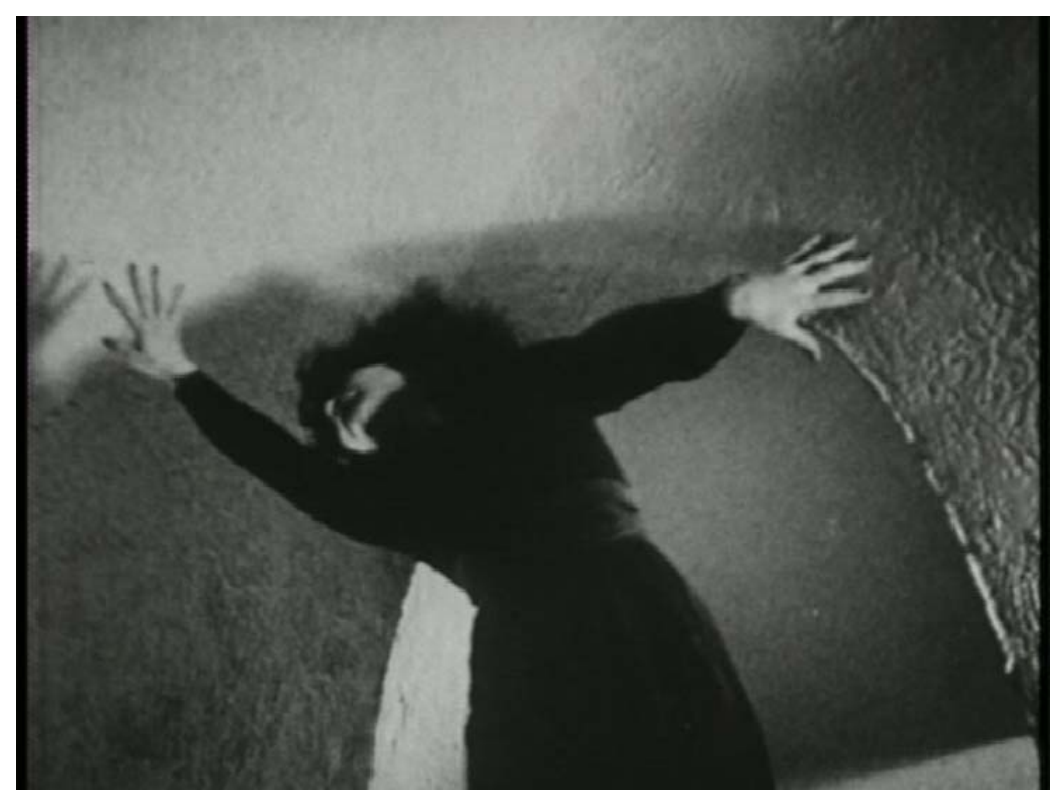

Cena do filme "Meshes of Afternoon"

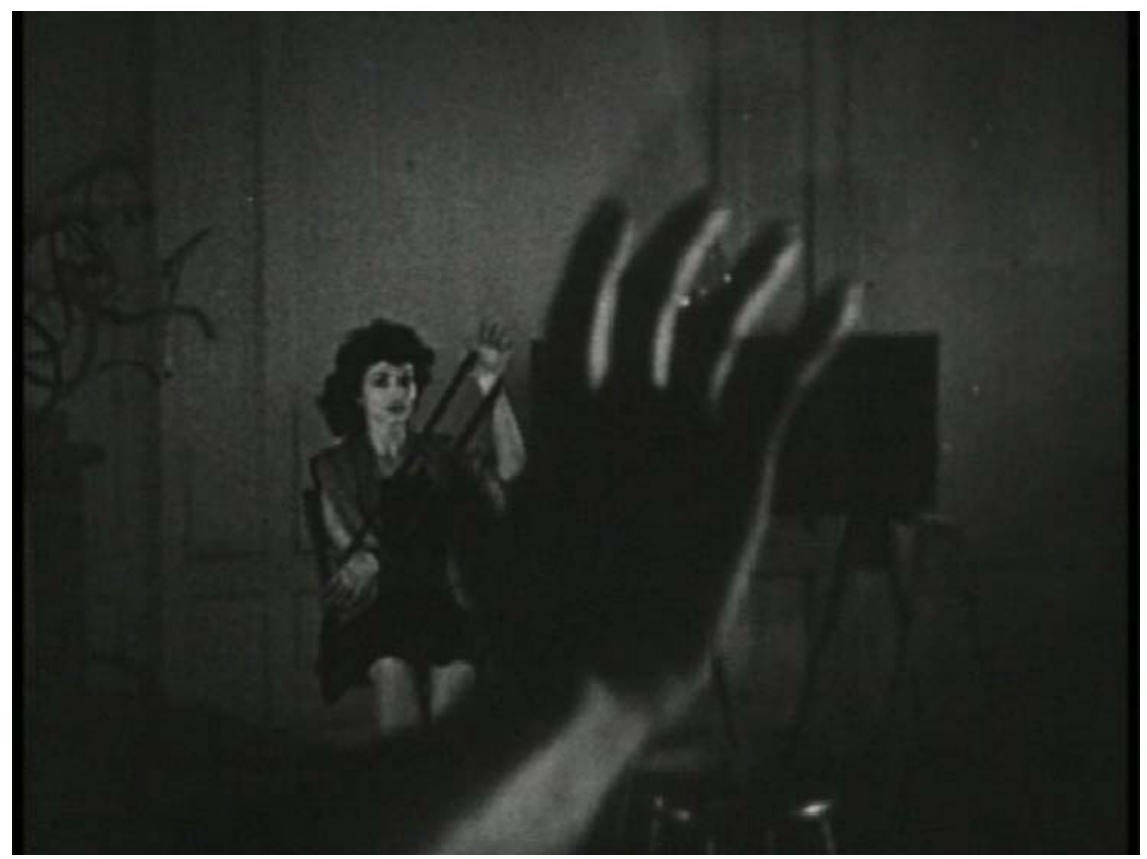


Cena do filme "Ritual in a Tranfigured Time"

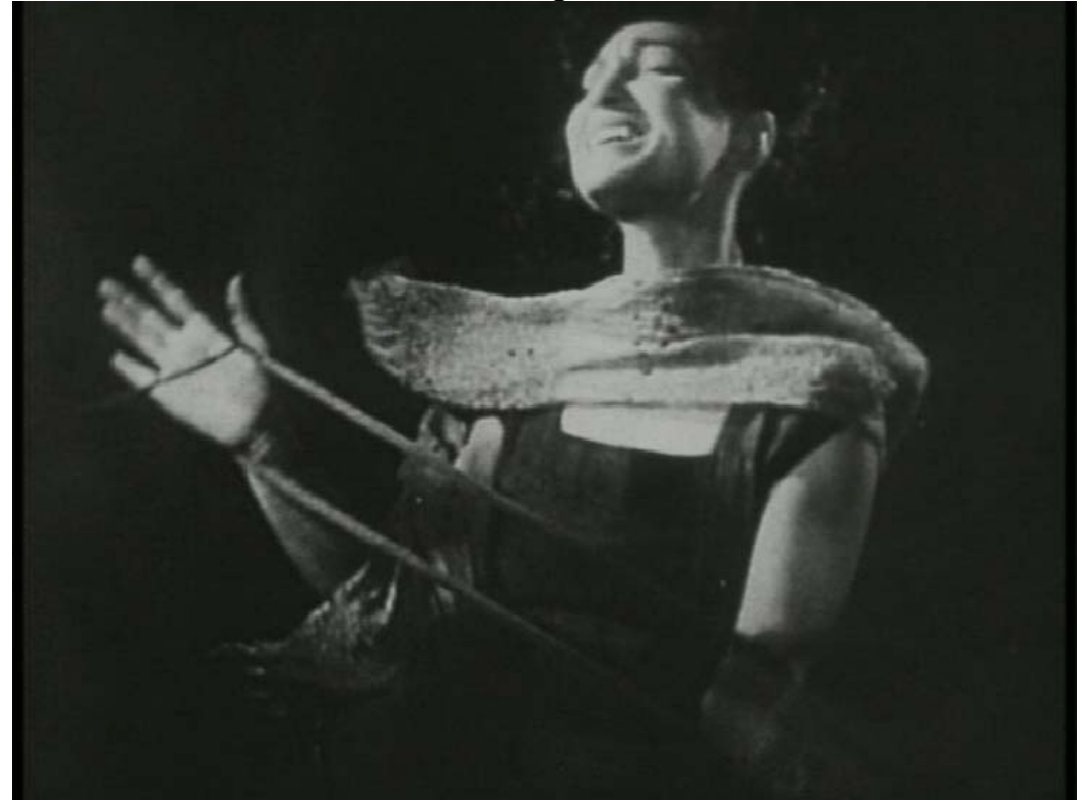

Cena do filme "Ritual in a Transfigured Time"

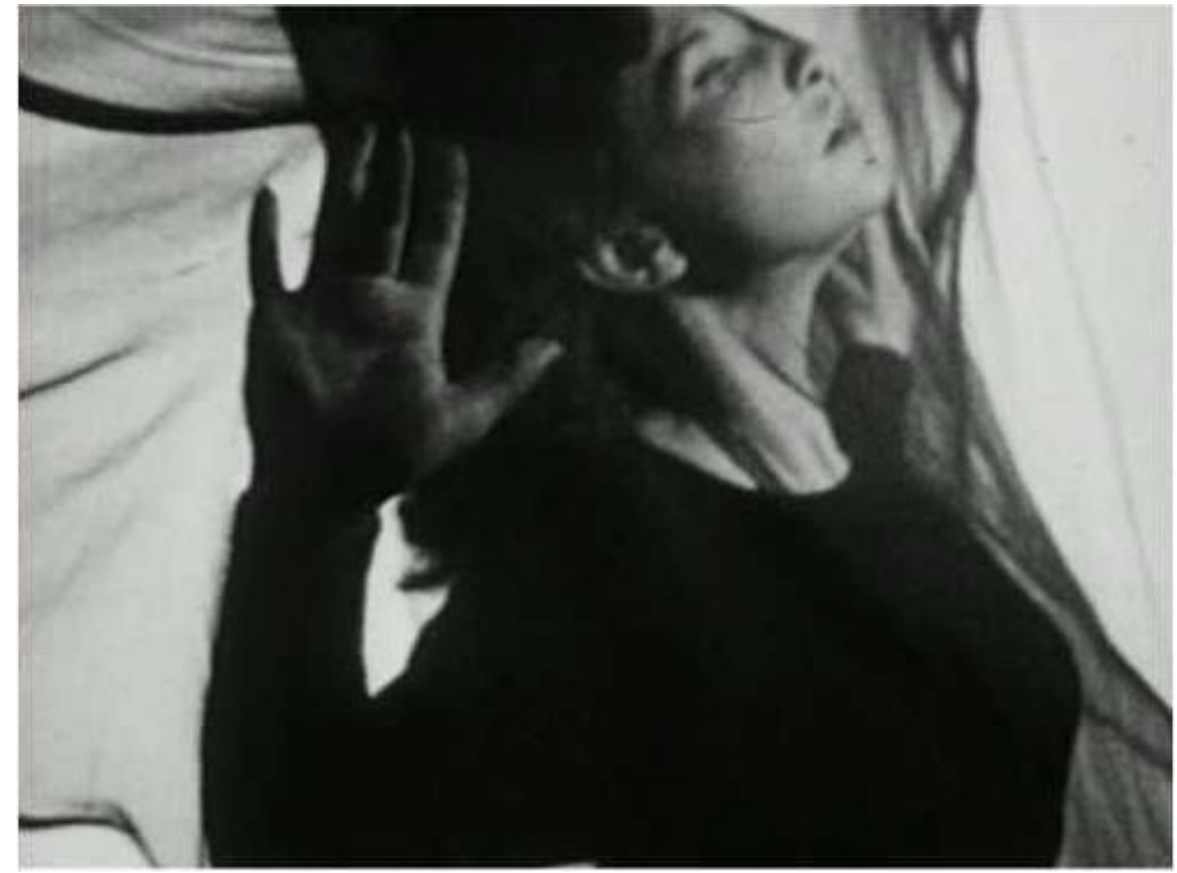

Cena do filme "Meshes of Afternoon" 


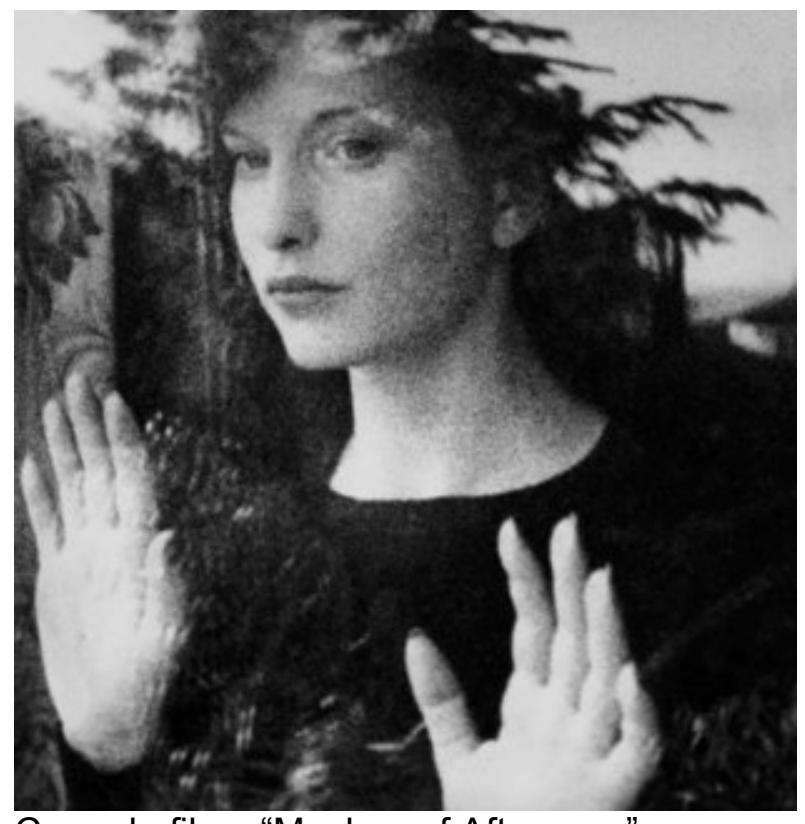

Cena do filme "Meshes of Afternoon"

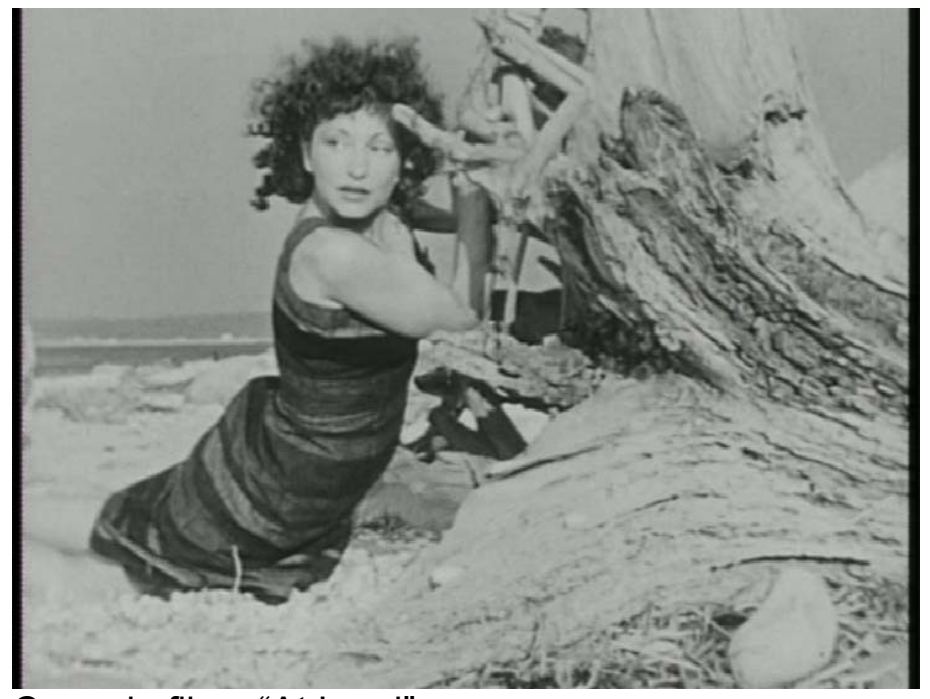

Cena do filme "At Land" 


\section{Outras Inspirações}

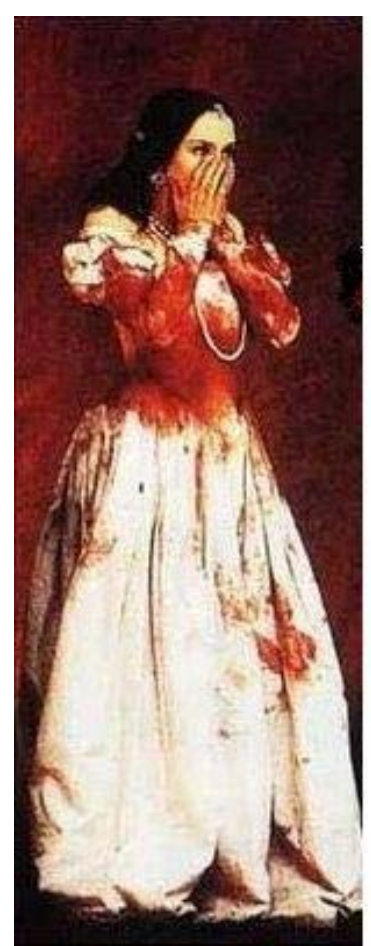

Foto do filme Rainha Margot

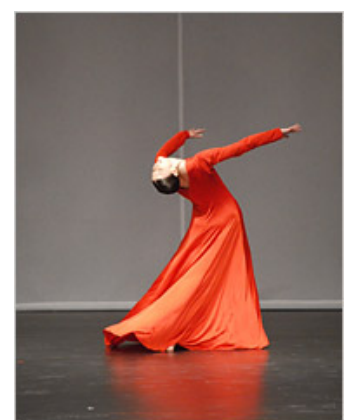

Foto de espetáculo de Pina Bausch

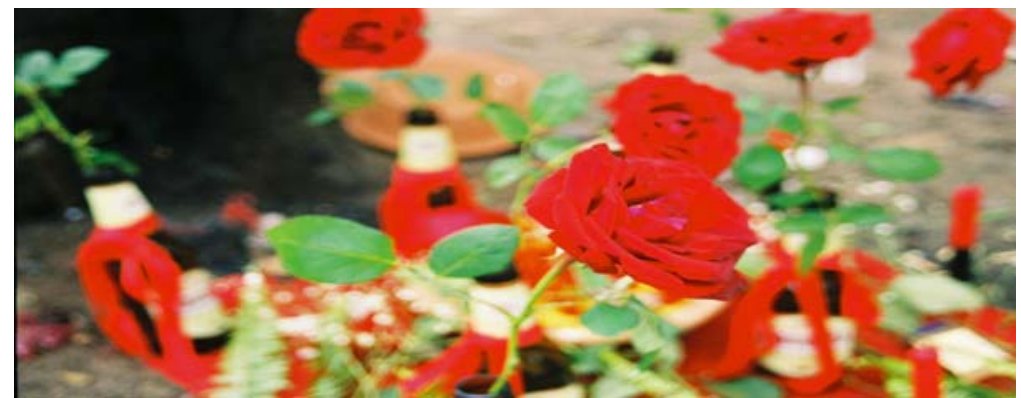

Despacho Instalação - terreiro de mãe Vanda 


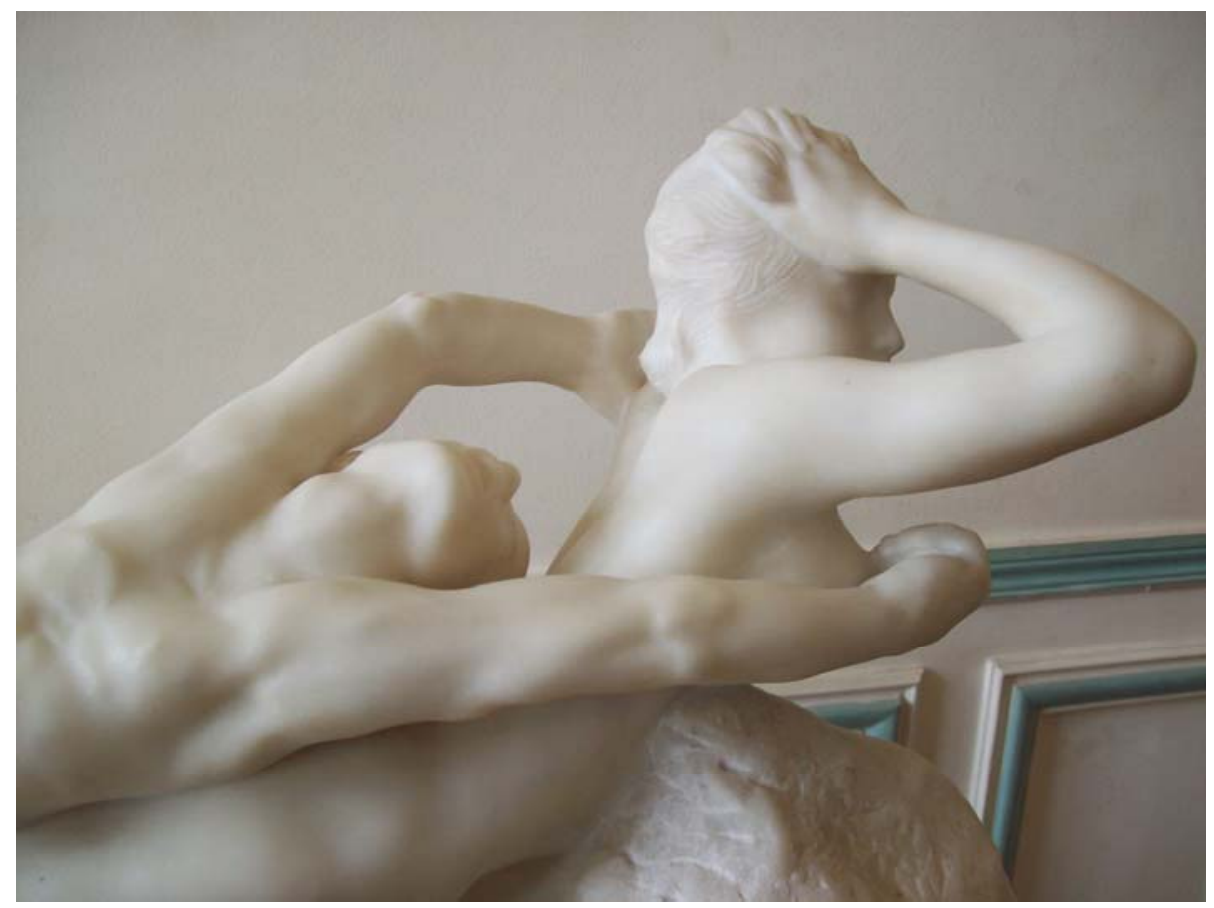

Fugit Amor - Museu Rodin

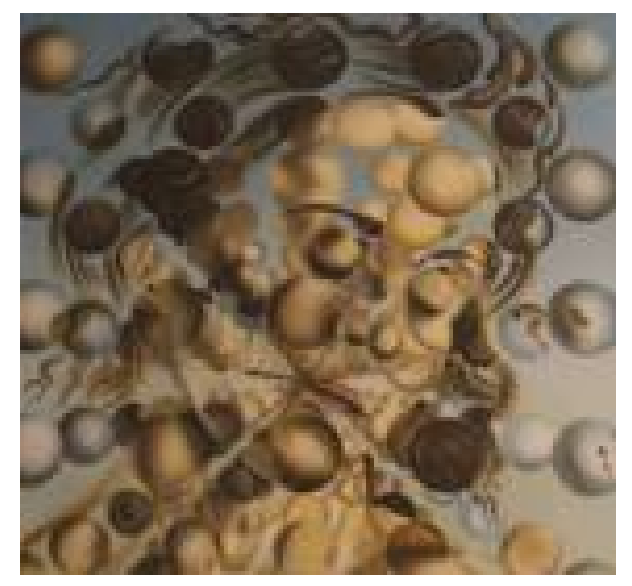

Foto do Museu Dali 


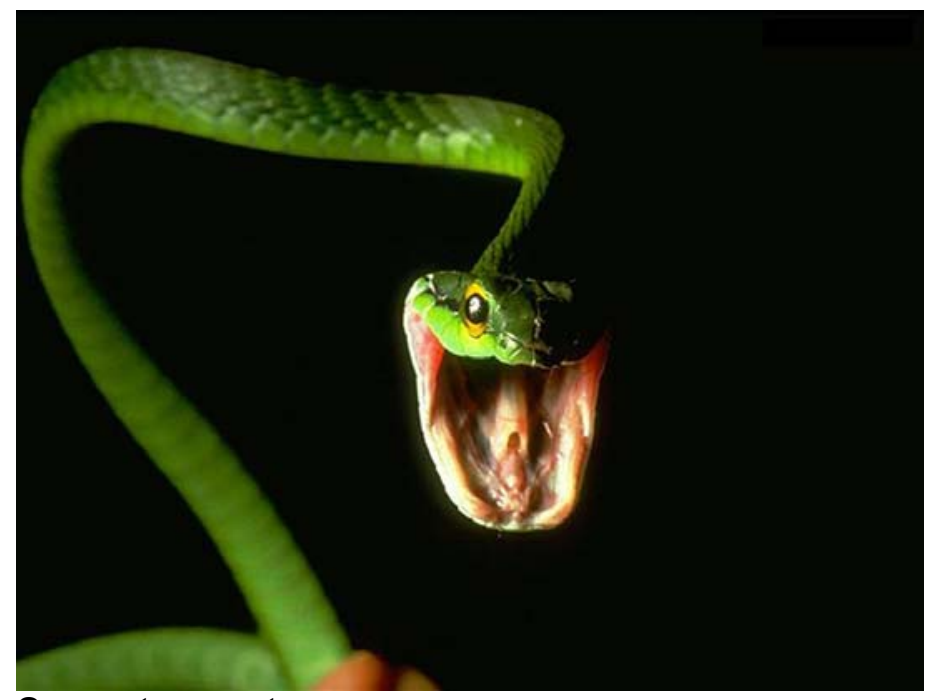

Serpente em ataque

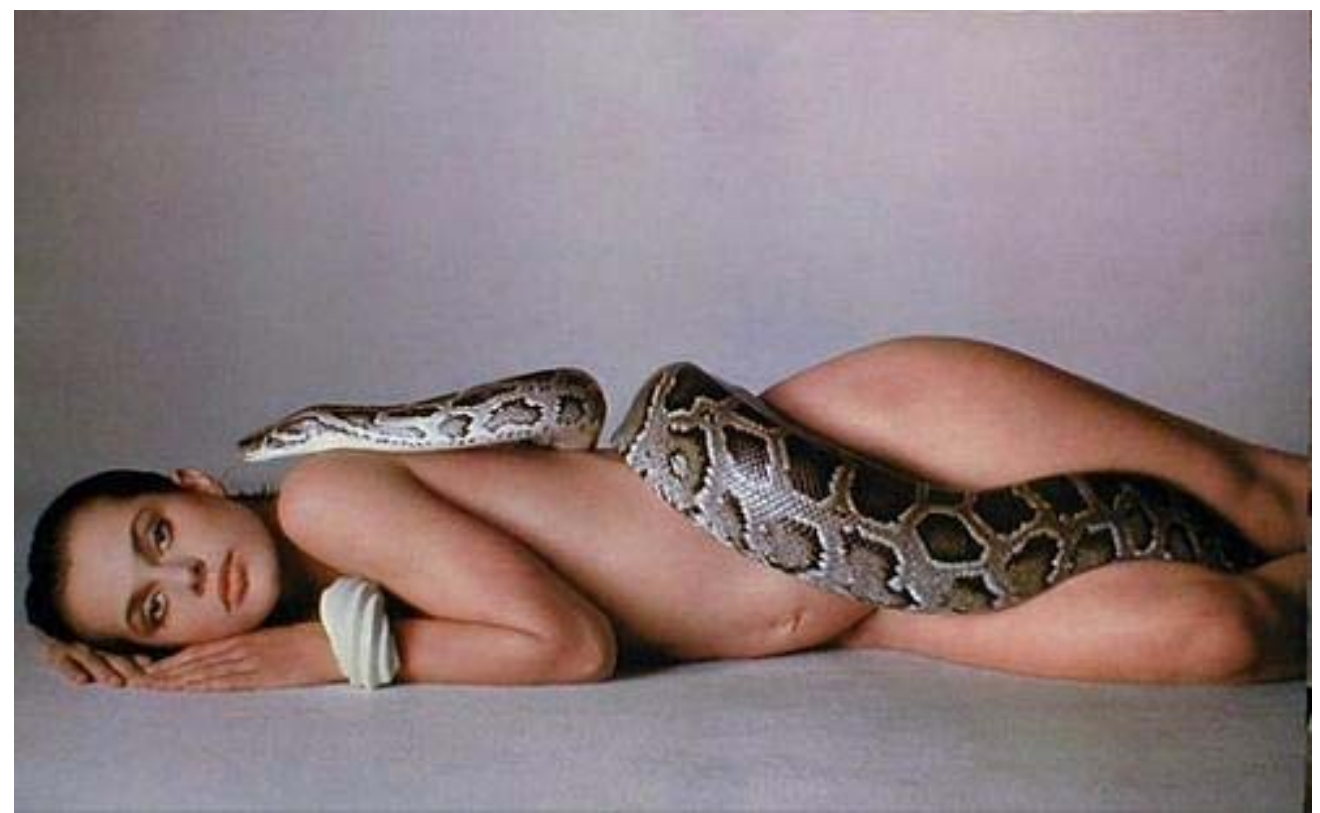

Serpente enroscando-se, envolvendo 


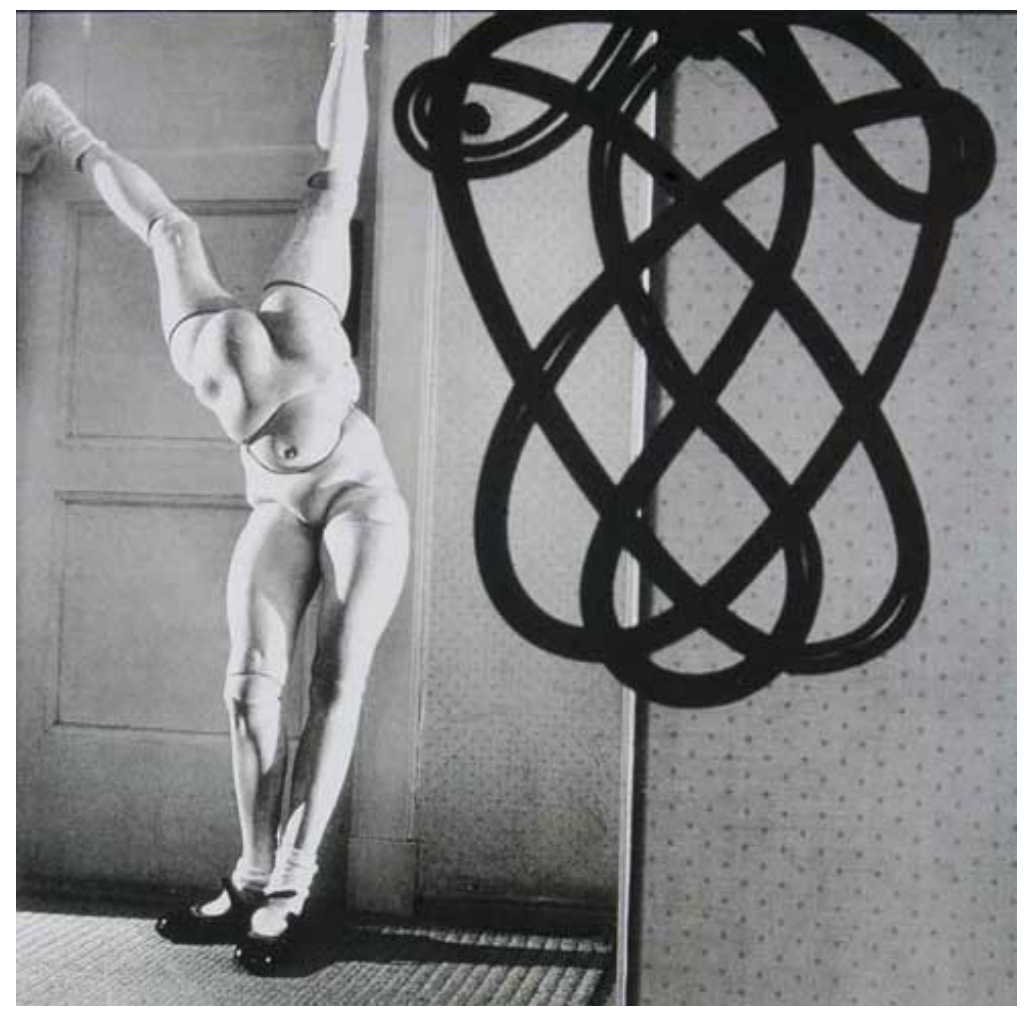

Hans Bellmer

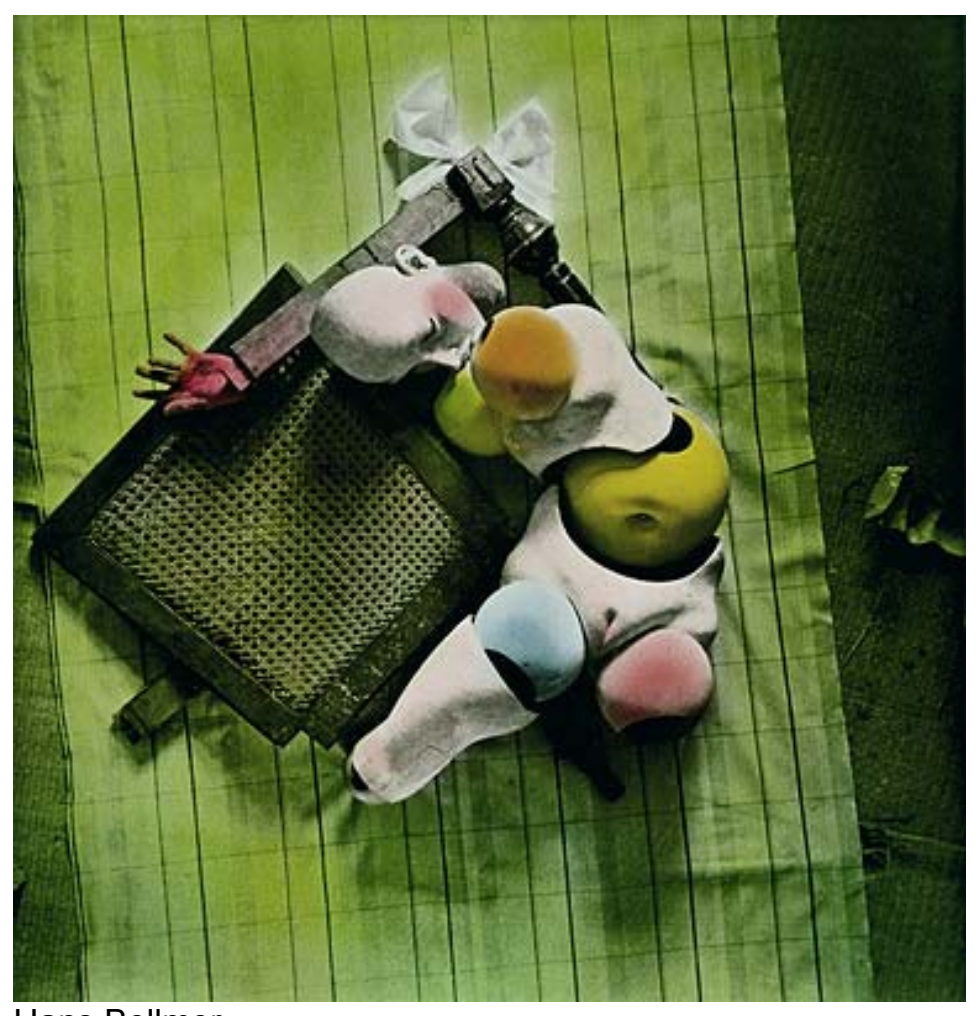

Hans Bellmer 

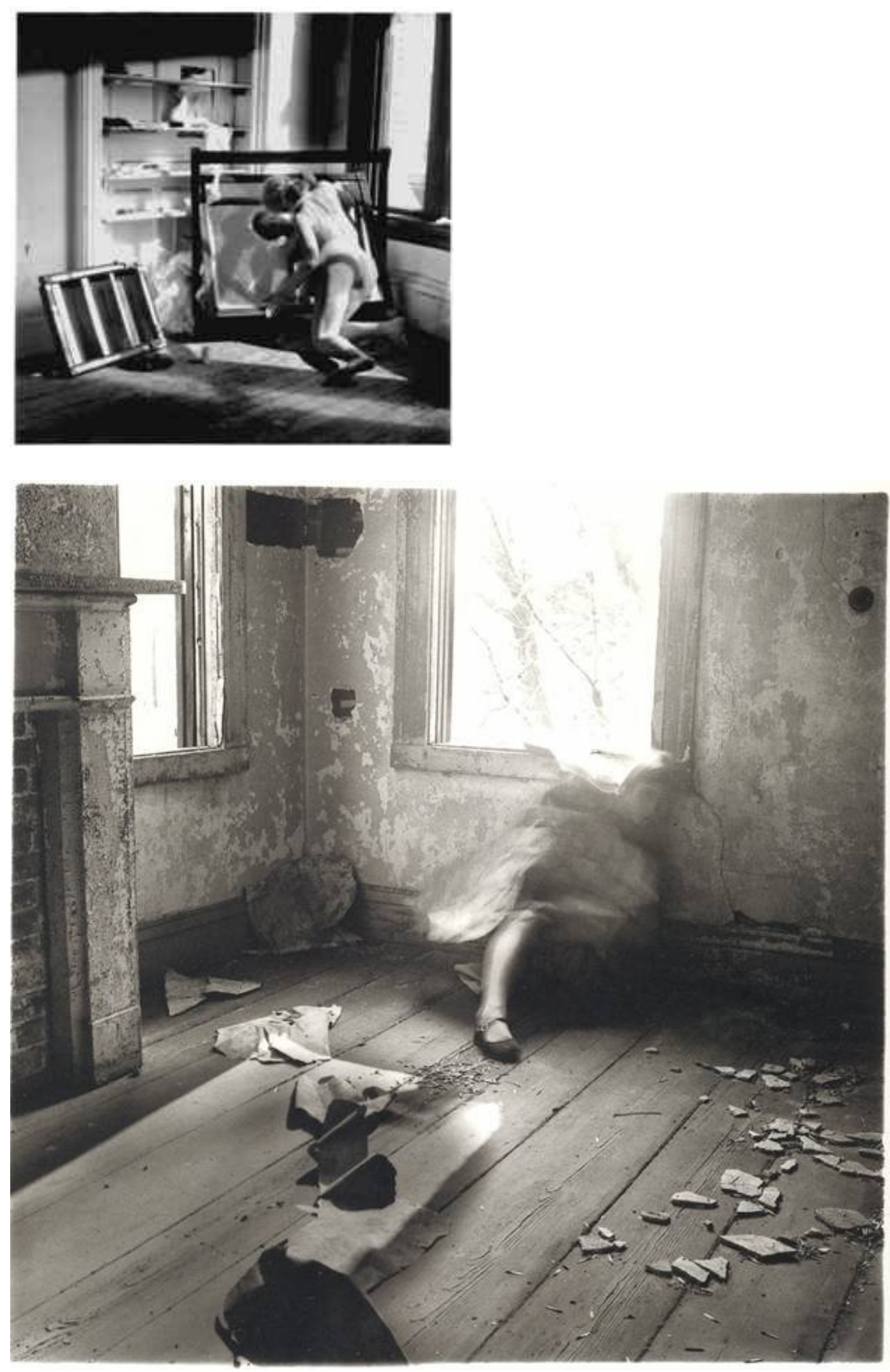


\section{Bibliografias}

Filmografias 


\section{Bibliografias}

\subsection{ARTES CÊNICAS - métodos, teatro contemporâneo e performance.}

ARTAUD, Antonin, “Linguagem e Vida”, Editora Perspectiva, 2004.

, "O Teatro e seu Duplo", tradução Teixeira Coelho, 3a. Edição,

São Paulo, Max Limonad, 1987.

, “Os Tarahumaras”, Lisboa, Relógio D’Água, 1985.

BAIOCCHI, Maura. Dança, Veredas d'Alma. Palas Athena. 1995

BARBA, Eugênio, "A Canoa de Papel - Tratado de antropologia teatral", São Paulo, Hucitec, 1994.

, "Além das Ilhas Flutuantes". São Paulo, Hucitec,1991.

, “A Arte Secreta do Ator". São Paulo, Hucitec,1995. Edição com

Nicola Savarese.

BONFITTO, Matteo, “O Ator Compositor”, São Paulo, Perspectiva, 2002.

BROOK, Peter. “O Espaço Vazio”. Vozes, 1970.

BURNIER, Luís Otávio. “A arte do Ator. Da Técnica a Representação”, Editora da Unicamp.

COHEN, Renato, "Performance como Linguagem: criação de um tempo-espaço de experimentação", São Paulo, Perspectiva e EDUSP, 1989.

ECO, Umberto. Sobre os Espelhos e Outros Ensaios. Editora Nova Fronteira. 1989. 
FERRACINI, Renato. "Arte de não Interpretar como Poesia Corpórea do Ator" Editora da Unicamp, 2004. . "Café com Queijo: Corpos em Criação" Editora Hucitec, 2006.

GROTOWSKI, J. "Em busca de um Teatro Pobre”. Civilização Brasileira. Rio de Janeiro, 1987

MAMET, David. "Os três usos da faca”. Civilização Brasileira, 2001.

OIDA, Yoshi. "O Ator Invisível”. São Paulo. Beca, 2001.

QUILICI, Cassiano Sydow: "Antonin Artaud - Teatro e Ritual”, Editora Annablume, 2004.

STANISLAVSKI, Constantin. "A Preparaçao do Ator". Editora Civilização Brasileira, 2006.

, “A Criação de um Papel". Editora Civilização Brasileira, 2006.

ROMANO, Lucia. "Teatro do Corpo Manifesto: Teatro Físico", Editora Perspectiva, 2005.

STOKLOS, Denise: “Teatro Essencial”, Editora Civilização Brasileira, 1990.

\section{2 - ARTES CORPORAIS e TERAPEUTICAS}

BEZIERS, Marie Madeleine, “A Coordenação Motora”, Editora Summus, 1992.

COHEN, Bonnie Bainbridge, "Sensing, Feeling and Action", Contact Editions, 1994.

KELEMAN, Stanley, “Anatomia Emocional”, Ed. Summus, 1992. , "Corporificando a Experiência”, Ed. Summus 1995 
, " O Corpo diz sua Mente”, Ed. Summus 1996

, "Mito e Corpo", Ed. Summus 2001

LABAN, Rudolf. “O Domínio do Movimento”, Ed. Summus, 1978.

, “Dança Educativa Moderna”, Ícone editora , 1990.

, "Choreutics" - Macdonald \& Evans London, 1966.

\section{$10.3 \quad-\quad$ CONTEMPORANEIDADE, INTERDISCIPLINARIDADE E} COMUNICAÇÃO.

AMARAL, Rita - "Xirê, o modo de crer e de viver no candomblé". Rio de Janeiro, Pallas, 2002.

BACHELLARD, Gaston, “A poética do espaço”, São Paulo, Editora Martins Fontes, 1998.

, "A Água e os sonhos", São Paulo, Editora Martins

Fontes, 2005.

, "A Intuição do Instante". Editora Verus. 2007.

BAITELLO, Norval et al. (Org.) "Os meios da incomunicação". SP, Annablume.

BASTIDE, Roger - “O candomblé da Bahia: Rito Nagô.” $3^{a}$ ed. São Paulo, Nacional, 1978.

,"Disciplina y espontaneidad en los trances afroamericanos", El sueño, el trance y la locura. Buenos Aires: Amorrortu Editores. 1972

BEY, Hakim, “Caos - Terrorismo Poético e Outros Crimes”, Editora Conrad do Brasil, 2003.

-, "TAZ -Zona Autônoma Temporária", Editora Conrad do Brasil, 
2001.

BORDWELL, D. Narration in the fiction film. London: Routledge, 1997.

CAMPBELL, Joseph, "O Poder do Mito", Editora Palas Athena, 2005.

CAPRA, Fritjof, “O Ponto de Mutação”, Editora Cultrix, 2004.

CHEVALIER, Jean, “Dicionário de Símbolos”, Editora José Olímpio, 1982.

DELEUZE, Gilles, “Diferença e repetição”, Rio de Janeiro, Graal, 1988. , e GUATTARI, Felix, “Mil platôs - Capitalismo e esquizofrenia”, Vol 1,

Rio de

Janeiro, Ed. 34, 1997

, Francis Bacon - Lógica da Sensação, Jorge Zahar, 2007.

DEREN, Maya. "An Anagram of Ideas on Art, Form and Film", 1946. The Alicat Book Shop Press, Yonkers, NY.

ECO, Umberto, "Sobre os Espelhos e Outros Ensaios", Rio de Janeiro. nova Fronteira, 1989.

FAGES, Jean Baptiste, “Para Compreender Lacan” 3a Edição. Editora Rio. 1977.

FOUCAULT, “Vigiar e Punir”, Vozes, 1987.

HILST, Hilda. “Fluxo-floema.”. Editora Globo, 2005.

JUNG, C. G., "O Homem e Seus Símbolos”, Editora Nova Fronteira, 2005.

KATZ, Helena, "Corpo-midia: instrumento pra caminhar na zona de fronteira" in Anais do $3^{\circ}$ Congresso Brasileiro de Pesquisa e Pós Graduação em Artes Cênicas, ABRACE, 2003.

, "Um, dois, três. - A dança é o pensamento do corpo", FID Editorial, 2006. 
NEgRÃo, Lísias Nogueira. "Entre a cruz e a encruzilhada: formação do campo umbandista em São Paulo." São Paulo, Edusp, 1996.

NICHOLS, Bill. "Maya Deren and the American Avant-Garde", University of Califórnia Press, Ltd. 2001.

QUINET, A. “Um Olhar a Mais: Ver e ser visto na Psicanálise”, Zahar, 2002.

PERNIOLA, Mario. "Pensando o Ritual - Sexualidade, Morte, Mundo", Studio Nobel, 2000.

PRANDI, Reginaldo. Mitologia dos orixás. São Paulo, Companhia das Letras, 2001.

PROCHNO, Caio César Souza Camargo, "Corpo do Ator. Simulacros e Metamorfoses", Editora Annablume, 1999.

SILVA, Vagner G - "Candomblé e Umbanda - Caminhos da Devoção Brasileira" . São Paulo, Ática, 1994.

- Orixás da Metrópole. Petrópolis, Vozes, 1995 (Cap. 4 - “A estrutura religiosa do candomblé - Rotinização dos Ritos")

SOUZENELLE, Annick. "Os Simbolismos do Corpo Humano", Editora Pensamento, 1984.

TURNER, Victor W. "The Ritual Process: Structure and Anti-Structure." NY: Cornell University Press. 1969.

VERGER, Pierre. Notas sobre o culto aos orixás e voduns. Tradução de Carlos Eugênio Marcondes de Moura, do original de 1957. São Paulo, Edusp, 1999. 


\title{
Filmografia
}

\author{
DEREN, Maya. "Meshes of the Afternoon" (1943) \\ "At Land" (1944) \\ , “A Study in Choreography for Camera” (1945) \\ , "Witch's Cradle" (1944) \\ , "Ritual in Transfigured Time" (1946) \\ , "Meditation on Violence" (1948) \\ , "The Very Eye of Night" (1958) \\ , "Divine Horsemen: The Living Gods of Haiti" (1985) (original
}

footage) 